\title{
O OLHAR DO IDOSO SOBRE SUA PRÓPRIA SAÚDE
}

\section{WALDILENE TELES SANTOS}

Tese de Doutorado apresentada ao Departamento de Prática de Saúde Pública da Faculdade de Saúde Pública da Universidade de São Paulo para obtenção do grau de Doutor.

Área de Concentração:

Serviços de Saúde Pública

ORIENTADORA: Prof Dra Alice Moreira Derntl

São Paulo

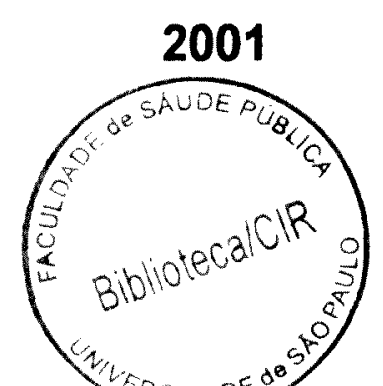


Autorizo, exclusivamente para fins acadêmicos e cientificos, a reprodução total ou parcial desta tese, por processos fotocopiadores.

Assinatura:

Data:

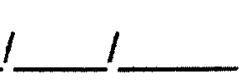


BANCA EXAMINADORA 
"Ora, a nosso Deus e Pai seja dada glória para todo o sempre". Paulo.

(Filipenses, 4:20).

Quando o vaso se retirou da cerâmica, dizia sem palavras:

- Bendito seja o fogo que me proporcionou a solidez.

Quando o arado se ausentou da forja, afirmava em silêncio:

- Bendito seja o malho que me deu forma.

Quando a madeira aprimorada passou a brilhar no palácio, exclamava, sem voz:

- Bendita seja a lâmina que me cortou cruelmente, preparando-me a beleza.

Quando a seda luziu, formosa, no templo, asseverava no intimo:

- Bendita seja a feia lagarta que me deu vida.

Quando a flor se entreabriu, veludosa e sublime, agradeceu, apressada:

- Bendita a terra escura que me encheu de perfume. 
Quando o enfermo recuperou a saúde, gritou, feliz:

- Bendita seja a dor que me trouxe a lição do equilibrio.

Quando eu termino de escrever este trabalho eu me curvo diante dos céus e digo:

- Benditas sejam as adversidades que tive de vivenciar pois me fizeram crescer e ser melhor.

Tudo é belo, tudo é grande, tudo é santo na casa de Deus.

Agradeçamos a tempestade que renova, a luta que aperfeiçoa, o sofrimento que ilumina.

A alvorada é maravilha do céu que vem após a noite na terra.

Que em nossas dificuldades e sombras seja nosso Pai glorificado para sempre. 


\section{DEDICATÓRIA}

Este trabalho eu quero dedicar àqueles que são o sentido da minha existência, à minha família.

Ao meu pai Waldo e à minha tia Socorro exemplos de sabedoria, dedicação, amor e alegria de viver.

Às minhas irmãs queridas, Rosangela e Eveline, que estão sempre ao meu lado compartilhando dos meus anseios e sonhos.

Aos meus queridos irmãos e cunhadas, Waldo Filho e Ana Paola, Douglas e Gislaine, Eberth e Louise que embora distantes estão sempre tão presentes me dando forças constantemente.

Aos meus sobrinhos e sobrinhas que me levam às emoçōes da juventude. A todos o meu imenso amor e carinho. 
Agradeço à:

Profa. Dra. Alice Moreira Derntl por ter me aceito como sua orientanda.

Ao CNPQ pelo apoio financeiro que a $\mathrm{mim}$ foi dado. 


\section{AGRADECIMENTOS}

Escrever este trabalho foi um desafio que por muitas vezes tive que parar, respirar fundo para não deixar que o desânimo tomasse conta de mim e me levasse a desistir.

Para conseguir alcançar a minha meta contei com o carinho, a ajuda e a força de pessoas que para mim se mostraram iluminadas.

Especialmente agradeço:

A Profa. Dra. Elisabeth Frohlich Mercadante, pela generosidade e acolhimento que demonstrou ao partilhar comigo seu saber me conduzindo ao término deste processo.

Ao Prof. Dr. Fernando Lefèvre, que com sua dedicação, paciência e muita competência me orientou quanto à questão dos Discursos Coletivos e muito aprendemos.

À Dna. Terezinha Orlando dos Santos e Dna. Ondina de Paula Saran dois seres grandiosos que foram pacientes comigo, confiaram em mim e me ajudaram muito dizendo sempre "não pare, siga em frente, você conseguirá".

Ao Prof. Mestre Albino Salgueiro por não medir esforços em sacrificar suas tardes de domingo me ajudando a refletir e escrever este trabalho.

Aos amigos queridos Walter e Zilda, Fátima e Minos, Salete, Patrícia e Maria José pela constante presença.

À Maria de Lourdes Possebon que esteve ao meu lado, suprindo o meu desconhecimento em informática. 
À Maria Cecilia Labriola responsável pela saúde ocular de Ars 7 -Secretaria Municipal de Saúde - por toda compreensão e incentivo nos momentos dificeis deste processo.

À Dra. Ariene C. Carvalho uma amiga e irmã pela amizade e estímulo.

À Profa. Mestra Cleunice Ritton pelo seu jeito paciente e compreensivo de ser.

À Darlene Dias da Silva, Diretora de RH - Ars 7, Secretaria Municipal de Saúde que em momentos de crise se mostrou disponivel para ouvir nossas lamúrias, ajudando e confiando sempre.

À Purificacion Navarro, que mansa e serenamente marcou presença em nosso cotidiano.

A todos da terceira idade, homens e mulheres, que nos ensinam uma nova forma de ser, ver e viver a vida. 


\section{RESUMO}

SANTOS, WT. O olhar do Idoso sobre sua própria saúde. São Paulo; 2001: [Tese de doutorado apresentada ao Departamento de Prática de Saúde Pública da Universidade de São Paulo para obtenção do graı de Doutor].

O envelhecimento populacional brasileiro tem sido um dos grandes desafios que a sociedade civil tem enfrentado. A questão da saúde também. Através do convivio com os idosos/alunos na Universidade para a Terceira Idade fui levada a questionar a visão de saúde na velhice devido à relação que se estabelece, culturalmente, entre doença e envelhecimento. $O$ ser idoso para esse grupo se mostrava diferente do preconizado pela sociedade para quem ser velho é ser doente, incapaz. Tendo em vista que a cultura exerce influência direta na maneira de pensar, agir e ser dos indivíduos e que esses reproduzem as crenças, os valores e simbolos, apreendidos através de seu ser e estar nessa sociedade, busquei estudar o significado que os idosos/alunos dão à sua própria saúde. Este estudo deu-se através de entrevistas semi-estruturadas, a partir de um roteiro para o pesquisador. Após transcritas as gravações, foram levantadas as idéias centrais e as expressões-chave, chegando-se ao discurso do sujeito coletivo e através da mesma à representação que o idoso faz de sua saúde. Consideramos que esses sujeitos fazem parte de um grupo de idosos que se sentem saudáveis, capazes de adquirir novos conhecimentos, fazer planos e buscar novos caminhos para prevenir sua saúde física e mental.

Descritores: Olhar - Saúde - Idoso. 


\section{SUMMARY}

SANTOS, WT. O olhar do Idoso sobre sua própria saúde. São Paulo; 2001: [Tese de doutorado apresentada ao Departamento de Prática de Saúde Pública da Universidade de São Paulo para obtenção do grau de Doutor].

To grow in the brazilian population has been a big challenge that the civil society has been facing. The questions and problems about health, too. Through the acguaintanceship with old students in the third age University I felt necessity to question the view of them about their on health, considering that in culture there are a relationship between oldness and illness. To be old for this group has a different meaning to the one preconized by the society to whom to be old is to be sick and inapt to do things. We know that the culture of a society act on the way the people are, think and do things. They usually reproduce the faiths, values and symbols through their way of be and stay in this society. So, l've studied the meaning that old people give for their on health. I've done this study through semi-structered interviews, after them l've transcribed the recording and the central ideas were lifted, then I've got the colletive discourse and finally I analysed them. Through the colletive discourse I found the representation that the old people make of their on health. I considered that the individuals represented a group of a healthy old people, capable to get new knowledge, to make plans and get different ways to prevent their mental and physics health.

Describers: To look at - health - old people. 


\section{ÍNDICE}

INTRODUÇÃO

\section{CAPÍTULO I}

1. Referencial Teórico Metodológico.................................... 19

1.1. O Ser Idoso ................................................. 21

1.2. A Saúde do Idoso ...................................... 38

1.3. Os Significados da Saúde para o Idoso.......... 60

1.4. Procedimentos da Pesquisa ......................... 75

CAPITULO II

2. Análise Temática ................................................. 90

2.1. Idéias Centrais e Expressões-Chave ................... 92

2.2. Sujeitos e seus discursos ............................... 103

Questão I ..................................................... 105

Questão II ...................................................... 109

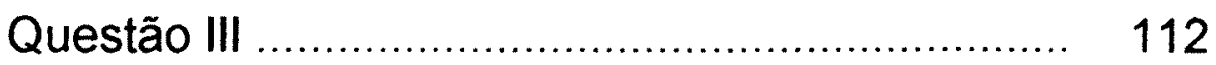

Questão IV ................................................... 115

2.3. Análise das Entrevistas ..................................... 118

INTERPRETAÇÕES DO PESQUISADOR .......................... 131

CONSIDERAÇÕES FINAIS ............................................... 135

BIBLIOGRAFIA CONSULTADA ....................................... 143 


\section{INTRODUÇÃO}

Biblioteca/CIR

FACULDADEDESAUUDE PÚBLICA

UNIVERSIDADE DE SAO PAULO 


\section{INTRODUÇÃO}

A saúde tem sido uma das maiores preocupaçōes de toda população brasileira. A situação de crise nesse setor vem se arrastando nessas últimas décadas. A penúria dos hospitais públicos, a indefinição de responsabilidades entre os governos federal, estadual e municipal no que concerne à saúde, o pagamento de salários irrisórios ao pessoal, a baixa qualificação profissional no setor, a proliferação de planos de saúde privados e uma fragilidade e ineficácia da política, a insensibilidade de parcela significativa de profissionais, traçam uma perspectiva muito pouco otimista em relação ao quadro de saúde no Brasil. Para os idosos, os efeitos são muito mais perversos.

Tendo em vista o convivio que tivemos com idosos, seja no Posto de Saúde, seja na sala de aula como professora, fomos levados a observar questões específicas da velhice e da saúde, de cada um deles. As disciplinas que eles escolhiam para cursar estavam relacionadas principalmente à sua saúde mental, ao bom funcionamento do cérebro, a sua autonomia e ao desempenho das atividades da vida cotidiana. As salas de neurolingüística, de auto-conhecimento, informática, cidadania, canto, dança e paisagismo, estavam sempre lotadas. Levavam com tamanha seriedade as aulas e as atividades que eram propostas, que me chamava atenção. A participação nos eventos dentro e fora da universidade, tais como as festas juninas no sítio de uma das professoras ou da chácara de alguns deles, a busca por pacotes de viagens pelo litoral ou mesmo para fo 3 do 
Estado de São Paulo, a disposição e o sentido de liberdade que deles emanavam me levaram a questionar o porquê daqueles idosos/alunos se apresentarem de uma maneira tão peculiar, diferente daquela imagem apresentada pela sociedade, do velho doente, triste, com perdas afetivas e materiais, sem disposição para fazer coisas diferentes das que faziam anteriormente, ou seja, a imagem de um ser declinante e improdutivo.

Os idosos/alunos vinham de cidades circunvizinhas para Bragança Paulista, tais como: Atibaia, Mairiporã, Piracaia, Socorro e Pinhalzinho, dirigindo seus próprios carros ou de carona.

Enquanto eu estava no posto de saúde e envolvia-me com as reuniões dos grupos de idosos, algo me chamava atenção: a freqüência a essas reuniões era sempre muito alta. Os idosos vinham à reunião por prazer, pelo desejo de conversar, rever os amigos, buscar informações que thes propiciassem uma melhor qualidade de vida. Essas reuniões eram realizadas em dias que não coincidiam com a consulta médico-clínica. As reuniões eram planejadas com a equipe multiprofissional contando sempre com a participação dos idosos. Os temas a serem discutidos eram escolhidos por eles $e$ as atividades, também. Eles estavam sempre produzindo trabalhos manuais, crochè, tricô, bordado, pinturas, para serem vendidos no bazar, organizado por eles mesmos e realizado no posto. Com o dinheiro arrecadado alugavam uma Van e faziam pequenas viagens Acompanhei-os a Itu, Santos, Aparecida do Norte e Embu. Eles se mostravam de forma diferente do velho estereotipado, não se colocavam 
como declinantes, tinham disposição, se locomoviam, alguns com um pouco de dificuldade; carregavam seus remedinhos na bolsa, outros já haviam desenvolvido alguma patologia clínica bem antes de chegar à Terceira Idade, mas isto não os tornava incapazes, já haviam aprendido a conviver com a doença, portanto não se viam doentes. Embora com mais de 60 anos, para eles, velho era sempre o outro, aquele que estava "prostrado" como eles diziam sempre.

Esse trabalho foi interrompido com a implantação do Programa de Assistência à Saúde - PAS nos postos de saúde e nós perdemos o contato com os grupos, que foram desfeitos, e nós transferidos para outra unidade da Secretaria Municipal de Saúde.

Continuamos nosso contato com os idosos/alunos na Universidade, como professora.

Entre essas duas populações havia diferenças, tais como: a econômica, social e educacional. No entanto, algo em comum existia: a disposição de buscar novos conhecimentos e informaçóes, fazer novas amizades, viajar, enfim se sentirem livres das obrigações que anteriormente os tolhiam.

Impossibilitada de investigar as duas populações direcionei a pesquisa para os idosos/alunos, uma vez que continuava próxima deles, na sala de aula 
Mostrou-se importante para mim, questionar a visão de saúde na velhice devido à relação que a sociedade estabelece entre doença e envelhecimento, mas de forma a direcionar o olhar do idoso para si mesmo.

O idoso, ao sinalizar, ou negar, sintomas do organismo em processo de envelhecimento, reflete influências sociais. Segundo a Organização Mundial de Saúde, "saúde é o estado de completo bem-estar físico, mental, social e ambiental, e não só a ausência de enfermidades." (1984). Relacionar o processo de saúde-doença aos processos sociais que a determinam é associá-la, também, à esfera do consumo e da produtividade, fatores que influenciam diretamente na questão do envelhecimento. $\mathrm{Na}$ sociedade industrial o velho passa a ser um fator de reduçăo de produtividade, cria-se uma ideologia quanto à velhice, faz-se do velho um ser descartável. Ao deixar de produzir adoece, deprime por se sentir inútil, não pode consumir nem seus próprios remédios, pois a aposentadoria que recebe não dá para sobreviver. Sentem-se humilhados por terem que depender da ajuda dos filhos ou familiares.

Enquanto questão humana e existencial, a saúde é uma problemática compartilhada indistintamente por todos os segmentos sociais. A questão do idoso também o é. As condições de vida e de trabalho qualificam de forma diferenciada a maneira pela qual as classes e seus segmentos pensam, sentem e agem a respeito da saúde e da velhice. Os velhos da classe dominante, têm problemas diferentes dos velhos da classe dominada e os resolvem de forma diferenciada, também. 
Para realizar esta pesquisa, busquei encontrar um campo propicio para essas indagações. Há inúmeras que abordam o tema saúde $\mathrm{x}$ idoso.Quatro me chamaram a atenção: uma na área médica, Saúde no Envelhecimento: O discurso sanitário nos programas de saúde (Departamento de Medicina Preventiva, 1996, USP); outra, realizada por um bioquímico: A Prescrição Medicamentosa sob a ótica do paciente idoso: relação com os profissionais de saúde (Departamento de Prática de Saúde Pública, 1998, USP); uma terceira realizada por assistente social: Práticas Terapêuticas nãoconvencionais usadas por idosos (Departamento de Prática de Saúde Pública, 1997, USP) e uma quarta realizada por psicóloga: As Interpretações Sociais da Saúde na Velhice, refletidas no uso do medicamento (Departamento de Prática de Saúde Pública, 1999, USP).

Após lê-las delimitei com maior clareza o tema que iria trabalhar.

Assim, direcionamos o objetivo do nosso trabalho para o significado que o idoso dá a sua própria saúde levando em consideração as interpretações culturais que perpassam a complexidade do tema. A velhice, a saúde ou a doença estão revestidas de conteúdos simbólicos, que evidenciam formas diversas de ação e representação. Não existe uma única forma de ser velho, de ser saudável, mas várias e diferentes que levam em conta, dentre os muitos aspectos, questões relativas ao gênero, à etnia, à classe social. 
Para chegarmos a essa compreensão necessitamos de um enfoque teórico-metodológico compativel com o levantamento do material a ser interpretado. Cliffort Geertz, (1989), antropólogo, ao colocar as representações como uma obra aberta, permitiu que recuperássemos uma postura essencial à minha prática profissional como Assistente Social e Educadora em Saúde Pública.

As reflexões de Simone de Beauvoir me orientaram teoricamente para a compreensão da velhice como um fenômeno biológico e cultural e, mais do que isso, para o entendimento da velhice como uma totalidade bio-sóciocultural.

O trabalho que aqui me proponho desenvolver é composto, além desta introdução, de dois capitulos, das interpretações feitas pelo pesquisador e das considerações finais.

O primeiro capítulo - Referencial Teórico Metodológico apresenta uma reflexão teórica e metodológica sobre as técnicas de pesquisa que norteiam este trabalho. O referencial teórico se desenvolve a partir das questões gerais do "Ser Idoso", da "Saúde do Idoso", e do "Olhar do Idoso para sua própria saúde". Aponta também, a relação necessária entre as questōes suscitadas pelo estudo e a metodologia adotada: entrevistas semiestruturadas, gravadas e transcritas realizadas a partir de um roteiro, para o pesquisador. 
No segundo capitulo - "Análise temática", as idéias centrais e as expressões-chave são levantadas e agrupadas para constituírem-se no discurso do sujeito coletivo. Comento as questōes levantadas e analiso as entrevistas de acordo com o olhar do idoso, tecendo considerações sustentadas pelo conteúdo desenvolvido no decorrer da pesquisa. Em seguida, apresento as interpretações feita pelo próprio pesquisador, sobre o discurso coletivo dos idosos/alunos.

Nas Consideracões finais busco apreender o significado que o idoso dá para a sua própria saúde, através do seu próprio olhar e não através do olhar dos outros. 
CAPÍTULO I 


\section{CAPÍTULO I}

\section{REFERENCIAL TEÓRICO METODOLÓGICO}

No presente capitulo, apresentamos uma discussão reflexiva sobre questões de ordem conceitual, teóricas e técnicas que nortearam este trabalho levando-se em consideração que a realidade social é o próprio dinamismo da vida individual e coletiva com toda a riqueza de significados dela transbordante. Essa mesma realidade é mais rica que qualquer teoria, qualquer pensamento e qualquer discurso que possamos elaborar sobre ela. (MINAYO, 1994: 15)

Conseqüentemente as questōes teóricas e metodológicas constituem-se uma exigência orientadora da tese, sendo ambas objeto de reflexão, constituindo-se num longo processo correlacional de leituras, discussões, pesquisa de campo, análise temática e interpretação de falas, sem constituirem-se, ao meu ver, fases estanques sendo que a metodologia "é o caminho do pensamento e a prática exercida na abordagem da realidade." (MINAYO, 1994: 16)

Nesse sentido, comungamos com o pensamento de Minayo quando coloca que "a metodologia ocupa um lugar central no interior das teorias e está sempre referida a elas." (1994: 16). Através da metodologia usada articulam-se conteúdos, pensamentos e existências. 
Em virtude do duplo sentido das discussões teóricas (objeto e norte da tese), a teoria e a metodologia caminham juntas, inseparáveis. A problemática teórica se desenvolve a partir das questões que se referem ao idoso e a consciência que ele possui de sua saúde. Vale dizer que o objetivo básico e fundamental é consignar que diante da problemática social $€$ cultural, o idoso adquire consciências diversas do que é a sua própria saúde. É bom ressaltar também que o trabalho retornará continuamente a elas, problematizando-as e destacando, no diálogo com a pesquisa, a sua capacidade de encontrar resposta ao problema levantado.

Esse trabalho representa um ponto de chegada inacabado, ou seja, está aberto para que outras questões sejam levantadas a respeito do significado que o idoso dá para sua própria saúde. 


\subsection{O SER IDOSO}

Entendemos que toda coletividade humana é cultural. As atividades exercidas pelo homem com o auxilio de instrumentos por ele fabricados, constituem um trabalho, um conjunto de valores sociais, a partir do qual se estabelece uma organização sócio-cultural.

O que diferencia as sociedades humanas são suas culturas especificas que implicam hábitos, costumes, crenças, valores. Cultura significa ações sociais e também as representações sociais sobre essas mesmas ações que os homens criam vivendo em sociedade. (GEERTZ, 1989).

Segundo o antropólogo Geertz (1989).

"A cultura de uma sociedade consiste no que quer que seja que alguém tem que saber ou acreditar a fim de agir de uma forma aceita pelos seus membros." (p. 21).

Os individuos de uma sociedade ao nascerem recebem uma carga de símbolos que representam o modo como se vive naquele meio. Ao crescerem reproduzirão o que significa estes símbolos para cada um. (GEERTZ, 1989).

Ao chamar a atenção para a ação dos membros de uma sociedade Geertz sinaliza, na verdade enfatiza imediatamente para o "saber", o "acreditar", para a dimensão simbólica da cultura. 
Assim sendo, ao definir cultura Geertz aponta que ela:

\begin{abstract}
"[.. ] denota um padrão de significados transmitido historicamente, incorporado em símbolos, um sistema de concepções herdadas e expressas em formas simbólicas por meio das quais os homens comunicam, perpetuam e desenvolvem seu conhecimento e suas atividades em relação à vida. " (GEERTZ, 1989: 103).
\end{abstract}

Tomando como exemplo os estudos realizados por Geertz (1989) sobre o significado da briga de galos na sociedade Balinesa, percebemos que esse tema assume vários conteúdos simbólicos, entre eles o de morte, masculinidade, raiva, orgulho, perda, beneficência, oportunidade. A briga de galos é um meio de expressão. A briga de galos é um texto denso que os balineses escrevem sobre eles mesmos como seres sociais vivendo em conflitos, paixōes, relações politicas, sociais e econômicas na sociedade.

Ao avaliar a análise da cultura, Geertz chama a atenção para um caminho a ser percorrido. Ele entende que nas percepções e interpretações de determinados fatos, as complexidades são possíveis se não praticamente infindáveis dada a hierarquia estratificada de estruturas significantes. O que consideramos como nossos dados são, na realidade, nossa própria construção, fruto das construções de outras pessoas, diferente do que elas e seus compatriotas se propuseram. A maior parte da compreensão de um acontecimento particular, um ritual, um costume, uma idéia ou o que quer que seja, está inserida no contexto como informação do que foi examinado diretamente. 
"O comportamento humano é visto como ação simbólica (na maioria das vezes; há duas contrações) - uma ação que significa, como a fonação na fala, o pigmento na pintura, a linha na escrita ou a ressonância na música - o problema se a cultura é uma conduta padronizada ou um estado da mente ou mesmo as duas coisas juntas." (GEERTZ, 1989: 19).

O que se deve indagar é qual a importância de determinado significado: o que esse transmite com a sua ocorrência. Ou seja, no que diz respeito ao objeto do nosso estudo, queremos entender qual o significado da saúde do idoso para ele mesmo. É um tema complexo, amplo, cujo entendimento exige-nos que para alcançarmos esses significados, temos que buscar o que representa, para cada um dos entrevistados, os símbolos interpretados por eles, dentro do grupo social a que pertencem. Ao chamar a atenção para a complexidade do tema, estamos cientes de que não há apenas uma forma de conhecimento que o explique, mas temos que levar em conta as diversas ciências humanas e biológicas, para servirem de base à nossa proposta de estudo.

Ser idoso em uma cultura pode representar a sabedoria, a consolidação da vida, da experiência dos anos vividos. Em outra, chegar a uma idade avançada pode representar a exclusão do movimento social. O indivíduo é deixado de lado, considerado incapaz, improdutivo, por perder a vitalidade, condição valorizada e que é atribuida aos jovens. Temos, a colocação de Galeno que nos mostra, como exemplo, a

"antiga sociedade romana que colocava a velhice como um miserável prolongamento da vida, assim como a juventude sena 
seu resplandecente prólogo. O homem só era digno de interesse na fase adulta. No periodo de renascimento europeu propriamente dito, predomina uma mentalidade de 'primavera e renovação', com exaltação da juventude, beleza e plenitude da vida. A morte, a decrepitude, a decadência sáo encaradas com horror". (1987: 217).

As sociedades capitalistas atribuem os significados acima colocados, aos idosos mas internamente eles lutam para diminuir ou acabar com o estigma, se envolvem, participam da vida social, como que provando que ainda estäo bem, podem produzir, aumentar seus conhecimentos ou mesmo adquiri-los, ou seja, rompem com as representações que Ihes são atribuídas. (YASBEK, 1996).

Encontramos na sociedade brasileira, uma gama idosos que se sentem discriminados, outros que estão aposentados, com produção relativa, estão saudáveis, podem usar o seu potencial de criatividade, não se permitindo, assim, serem excluidos e buscam meios para provar a si próprios e à sociedade que espera deles um comportamento estereotipado, que podem ser diferentes. (BEAUVOIR, 1990).

A expansão das populações mais velhas no Brasil há que ser enfrentada primeiro pelo próprio contingente idoso, enquanto cidadão de direitos e deveres. Para isso ser viável, há que se mobilizar todos os espaços políticos, desde as próprias familias, passando pelos grupos religiosos, pelas universidades, pelas associações de moradores e de aposentados e pensionistas, chegando até as esferas de decisão política. (GOLDMAN, 1999: 3). Partindo daí, poderão 
desenvolver uma nova sociabilidade, Ihes sendo permitido voltarem o olhar sobre si mesmos e mostrarem inteligentemente do que são capazes.

Temos conhecimento que o processo de envelhecimento é um fenômeno que percorre toda a humanidade, mas apresenta características diferenciadas de acordo com a cultura.

Destacando a trajetória histórica da questão da velhice em algumas sociedades, Callis (1996), procura demarcar as diferenças culturais nas formas de encarar e de tratar os idosos. Remete-se às civilizações diferenciadas, como os esquimós (hoje conhecidos como Inuites), que são incitados ao suicídio, enquanto entre os hotentores, nas África, só são respeitados os idosos lúcidos. Os idosos na cultura dos Yahgans, na Terra do Fogo, que são respeitados como detentores do saber e fazem parte do "Conselho dos Velhos", instância deliberativa máxima da comunidade. No Sudão, a comunidade dos Zandas também respeitam os velhos por considerá-los detentores do poder mágico, situação semelhante dos indios Navajo. Na China há uma filosofia que valoriza o idoso, respaldada em Confúncio e em Lao-Tsé, segundo o qual "é aos 60 anos que o homem se torna capaz de se libertar de seu corpo e de se tornar santo." (p. 24).

O autor se refere ainda a Platão e Sócrates, no livro "A República", publicado por Platão no século IV a.C. "Para indivíduos prudentes e bem preparados, a velhice não se constitui peso algum..." [Sócrates] "A velhice 
faz surgir em nós, um imenso sentimento de paz e de libertação." [Platão]. (CALLIS, 1996:24).

$\mathrm{Na}$ nossa sociedade, estudos antropológicos, por exemplo, de Debert (1988), Mercadante (1997), chamam a atenção para a existência de um modelo genérico de velho. Isso quer dizer que as qualidades a ele atribuídas são estigmatizadoras e contrapostas às atribuidas aos jovens. Assim sendo, as qualidades: atividade, produtividade, memória, beleza e força são características presentes nos individuos jovens e as qualidades opostas a estas últimas figuram nos idosos. É essa contraposição que estigmatiza, que cria uma visão generalizada sobre o ser velho. Também são os trabalhos de Debert e Mercadante que indicam que os idosos reconhecem esses modelos; não os negam socialmente, mas como indivíduos singulares, não se classificam nos mesmos.

Constróem-se novos estereótipos do "idoso com aparência/ comportamento jovem", do "idoso produtivo", do idoso que freqüenta grupos de cultura e lazer. Note-se que já não se fala mais de "velhos", termo politicamente incorreto para falar do ser que envelhece. Fala-se de uma etapa da vida como Terceira Idade e, aparece o antigo "velho" sob uma nova roupagem. Criam-se, ao nosso entender, novos estereótipos, onde o ser que envelhece é cobrado para se integrar em atividades físicas, culturais e de lazer, mesmo que seu interesse por isso passe logo. 
A velhice é uma questão complexa como já apontada anteriormente e não resta dúvida de que ela deve ser entendida como um fenômeno biológico, mas, entendê-la só dessa maneira, significa reduzir a questão e não analisála em sua totalidade e complexidade, o que implica não levar em conta os aspectos psicológico, social e, principalmente, cultural. O cultural é fundamental para a construção da complexidade no sentido de interpretar os significados da velhice.

Ao encontro do nosso pensamento vêm as palavras de Geertz (1989), que afirma:

"[...] o homem é um animal amarrado a teias de
significados que ele mesmo teceu, assumo a cultura
como sendo essas teias e a sua análise; portanto, não
como uma ciência experimental em busca de leis, mas
como uma ciência interpretativa, à procura do
significado. É justamente uma explicação que eu
procuro, ao construir expressóes sociais enigmáticas na
sua superficie." (p. 15).

A cultura é um ingrediente, e não um suplemento de pensamento. $O$ conceito de cultura implica a aceitação do pressuposto de que não existem homens não modificados pelos costumes de lugares particulares. Em oposição à perspectiva generalista, em que a individualidade é secundária, na perspectiva culturalista o homem deve ser definido pelos elos entre as suas habilidades inatas e o seu comportamento real, em constante mutação (MERCADANTE, 1997: 25). 
Jung (1990), nos chama atenção para o seguinte:

"O homem na segunda metade da vida está, naturalmente, orientado para a cultura, enquanto as forças decrescentes de seu organismo permitem-the subordinar seus instintos aos pontos de vista culturais. Falta-lhe, por assim dizer, todo e qualquer guia para esta passagem, extraordinariamente importante, da atitude biológica para a atitude cultural, para a transformação de energia da forma biológica na forma cultural. Este processo de transformação é de natureza individual e não pode ser imposto por regras e prescriçס̄es gerais. A transformação da libido se opera através do simbolo." (p. 59).

Discordamos da primeira parte da afirmativa acima, tendo em vista que o homem já nasce na cultura e assim não é na segunda metade da vida que ele é orientado para a vida sócio-cultural. Nessa fase da vida ele irá, sim, reproduzir o que foi apreendido. Não há como separar os individuos da cultura, no sentido geral e na medida em que nascem e se criam em uma cultura particular eles são singulares.

Assim, "a transformação da energia psiquica pode ser conquistada através de novos símbolos, como a dança, a pintura, os esportes, o canto, a escrita e a leitura, as viagens, a aprendizagem de novos idiomas, bem como das novas tecnologias, dos relacionamentos, do exercicio da cidadania, enfim, de todo desejo que possa haver em cada um". (RITTON, 2000: 113)

Voltamos a Geertz porque o seu pensamento define de forma clara e enfática a cultura. Assim sendo, esse autor afirma: 
"Como sistemas entrelaçados de signos interpretáveis, a cultura não é um poder, algo ao qual podem ser atribuidos casualmente os acontecimentos sociais, os comportamentos, as instituições ou os processos; ela é um contexto, algo dentro do qual eles podem ser descritos de forma inteligivel." (GEERTZ, 1989: 24).

Devemos atentar para o comportamento, e com exatidão, pois é através do fluxo do comportamento - ou, mais precisamente, da ação social - que as formas culturais encontram articulação.

"O significado emerge do papel que desempenham no padrão de vida decomente, năo de quaisquer relações intrinsecas que mantenham umas com as outras". (GEERTZ, 1989: 27).

Assim, quando se procura uma definição de homem depara-se com a sociedade e cultura em que ele está inserido. Diz Beauvoir: "O homem não vive nunca em estado natural; na sua velhice, como em qualquer idade, seu estatuto Ihe é imposto pela sociedade à qual pertence." (1990: 15).

O homem é um ser "bio-psico-sócio-cultural" que se desenvolve no seio de uma sociedade, e esse desenvolvimento depende estreitamente da natureza dessa sociedade e do lugar que nela ocupa esse ser.

Concordamos quando Geertz nos diz que a força de nossas interpretações não pode repousar, na rigidez com que elas se mantêm ou na segurança com que são argumentadas. (1989: 35).

Geertz nos remete também para a seguinte conclusão: 
"No estudo da cultura, os significantes não são sintomas ou conjuntos de sintomas, mas atos simbólicos ou conjuntos de atos simbólicos e o objetivo não é a terapia, mas a análise do discurso social." (1989: 36).

"A cultura de um povo é um conjunto de textos. As sociedades, como as vidas, contêm suas próprias interpretações. É preciso apenas descobrir o acesso a elas." (GEERTZ, 1989:26).

Assim, a condição do idoso depende do contexto social. Pensando na nossa sociedade, vemos que sobre ele "exerce um destino biológico que acarreta fatalmente uma conseqüência econômica: a improdutividade. Tornar-se improdutivo é uma "fatalidade" na interpretação da sociedade, individualmente, ele não é necessariamente um ser improdutivo." (BEAUVOIR, 1990: 249).

Ligando as explicações de Geertz com as reflexões de Simone de Beauvoir, vemos que as sociedades, os contextos sociais culturais, mais inclusivos, através de seu imaginário social interpreta o que é o ser idoso, o que significa ser velho.

A interpretação da nossa sociedade, da sociedade capitalista, em relação ao idoso, enfatiza características de um corpo - corpo envelhecido - corpo incapaz de exercer as atividades produtivas exigidas pelo sistema.

Ser produtivo nessa sociedade é um valor, isto não quer dizer que o idoso, individualmente, não seja produtivo, porém ele não é visto 
individualmente, ele é visto socialmente dentro de uma categoria genérica com qualidades também gerais e negativas como: "improdutivo", "inativo", "decadente".

Assim sendo, concordamos com Beauvoir quando afirma que há um destino biológico - corpo do idoso - que leva fatalmente para uma conseqüência econômica que é a improdutividade.

Voltando as reflexões de Beauvoir temos o que se segue:

"Nas sociedades capitalistas se leva em conta quase exclusivamente o interesse da economia, isto é, do capital, e não o dos individuos. Eliminados muito depressa do mercado de trabalho, os aposentados constituem um encargo que as sociedades baseadas no lucro assumem de maneira mesquinha. A solução mais correta seria permitir aos trabalhadores que continuassem ativos enquanto pudessem, garantindo-Ihes, em seguida, uma existência decente." (BEAUVOIR, 1990: 250).

Quando se tira do individuo a possibilidade de trabalhar, e isso principalmente no mundo ocidental, condena-se a maioria deles à miséria, à inércia, à solidão e ao tédio.

Percebemos que o individuo ao se afastar do trabalho fica desorientado porque não se preparou para romper com uma rotina construida de muitos anos onde sua vida girava em tomo da correria do dia-a-dia, da produção, do tempo. Esse individuo não se permitia desfrutar da ociosidade, ou muitas vezes não podia. Então, quando se tira dele a possibilidade de trabalhar, de ser útil, é o mesmo que condená-lo à miséria, pois os beneficios que irá receber, muitas vezes, não 
serão suficientes para realizar os sonhos para os quais, outrora, não tinha tempo disponivel para realizá-los devido aos compromissos com o trabalho, com a familia, com o lar. Aparece a sensação de inércia, tédio, solidão.

A sociedade capitalista estratifica as fases da vida humana podendo desvirtuar as condições de pensamento e sentimento dos idosos. Quando se observa o velho em nossa sociedade e, conseqüentemente, o que a velhice significa para ele, adquire-se a consciência de que a estigmatização é sua identidade. Ser velho significa não ser produtivo; ser decrépito; não ser belo, ágil; ser doente, no final e, principalmente, não entender o "moderno", não conseguir ter desejos e projetos (MERCADANTE, 1997:75).

Que é, pois, ser velho na sociedade capitalista? É sobreviver sem projeto, impedido de lembrar e de ensinar, sofrendo as adversidades de um corpo que se desagrega? (BOSI, 1987: XVIII). É ser globalizado? Adquirindo conhecimento das novas tecnologias, tais como: manusear um computador, usar a internet, usar um celular, ter microondas?

Encontrar ocupações é, portanto, uma questão de fundamental importância para as pessoas idosas. Nas ocupações, vislumbram-se o equilibrio mental, sentimental, a estruturação física e até perspectivas econômicas. Deve-se explorar a criatividade do idoso e a aquisição de novas habilidades e conhecimentos como um recurso para melhorar sua qualidade de vida. (FERRARI, 1999: 202). 
De Masi (2000), no seu livro "O Ócio Criativo", nos leva a uma outra reflexão quanto à questão da produtividade:

"A sociedade industrial permitiu que milhões de pessoas agissem somente com o corpo, mas não thes deixou a liberdade para expressar-se com a mente. Na linha de montagem, os operários movimentavam máos e pés, mas não usavam a cabeça. A sociedade pós-industrial oferece uma nova liberdade: depois do corpo, liberta a alma." (p.15).

E nos diz mais:

"Aos humanos, no trabalho ou no ócio, resta a interessante tarefa de serem criativos." (DE MASI, 2000: 18).

Não se pode negar o valor do pensamento de De Masi, entretanto são imperiosas as dificuldades para se pôr o mesmo em prática, pois não se abandonam de imediato os hábitos adquiridos, quiçá até impostos. Os indivíduos estão habituados a desempenhar funções que se repetem na vida cotidiana e é necessário um grande esforço para aprender uma atividade criativa e condigna.

É decorrente desta dificuldade que o idoso se sente inativo, deprimido, sozinho. Resta, na maioria das vezes, a doença por conseqüência. " $A$ Sociedade Industrial se caracteriza pelo frenesi da precisão, pela preferência da quantidade em vez da qualidade, pela planificação da produção e do consumo." (DE MASI, 2000: 298).

De Masi, ainda, em suas análises sobre o ócio criativo, nos mostra que: 
"Infelizmente, todas as instituições que cuidaram da gente - a família, a escola, e as instituições religiosas - nos prepararam, de uma forma obsessiva, para trabalhar, negligenciando a educação para o lazer, identificado só como consumo exibicionista." (DE MASI, 2000: 299).

E o idoso que faz parte desta sociedade capitalista, não entende e não sabe aproveitar, criativamente, o seu tempo livre. Às vezes não pode, por encontrar-se doente, ou sem condições financeiras, sua renda mensal é infima e não lhe permite assumir outras dividas além das que já tem.

O tempo livre para De Masi: "Significa viagem, cultura, ginástica, esporte, repouso, meditação. Significa, antes de tudo, nos exercitarmos para descobrir, desde hoje, o que podemos fazer no nosso tempo disponivel, sem gastar um tostão: passear sozinhos ou com amigos, ir à praia, assistir a um festival na televisão, ler um livro, balançar-se numa rede, que é o símbolo, por excelência do ócio criativo." (2000: 300).

O que precisamos fazer é dar sentido às coisas de todo dia, em geral lindas, sempre iguais e diversas e que, infelizmente, ficam depreciadas pelo uso cotidiano, rompendo, sem culpa, sem medo, com os simbolos postos pela cultura ao cidadão idoso. (DE MASI, 2000: 301).

Com certeza, isso levaria os idosos a uma "desorientação enquanto não se libertarem do tabu da laboriosidade como um fim em si mesma e não se converterem, sem complexos de culpa, da obsessão do bem-feito ao prazer do bem-estar." (DE MASI, 2000: 304). 
Para o corpo do idoso, não se dispõe de peças de reposição novas e prontas para o uso, pelo menos enquanto não dispusermos de clones. $O$ nosso "ferro-velho" consiste na eventualidade de que alguém, vivo ou que tenha acabado de morrer, nos doe seus órgãos ainda ativos. (DE MASI, 2000: 18).

Assim, ser idoso, na forma como cada grupo social representa e vive sua respectiva velhice, apresenta características peculiares. Certamente, há peculiaridade comum a este segmento da população, que é a recusa ao modelo social genérico de velho. Hoje, diante dos questionamentos constantemente levantados, percebe-se que há uma tentativa de se olharem como sujeitos plenos, cheios de vida, rechaçando a idéia de fím de vida, como o modelo social de velhice sugere.

"Os indivíduos não se sentem velhos em todas as situações e nem se definem velhos em todos os contextos." (MERCADANTE, 1997: 26)

O Prof. Joel Martins em sua palestra sobre "o ser e o tempo", abril de 1991, nos diz que: "numa sociedade de classes, a postura do humano, é vista de forma determinada". E que: "a conceituação de tempo que está implicita na concepção assumida pelo senso comum, e que é formulada como uma seqüência de agoras, não tem apenas a desvantagem de tratar o passado e o futuro como presente, ela é inconsistente, uma vez que destrói a verdadeira idéia de agoras como totalidades". (MARTINS, 1991:14).

Finalizo essa parte concordando com a afirmativa de Geertz (1989; 
"No estudo da cultura, os significantes não são sintomas ou conjuntos de sintomas, mas atos simbólicos ou conjuntos de atos simbólicos e o objetivo não é a terapia, mas a análise do discurso social." (p.36).

Entendemos que "o poder simbólico é um poder de construção da realidade que tende a estabelecer o sentido imediato do mundo, em particular, do mundo social. Os símbolos são os instrumentos por excelência da "integração social"; enquanto instrumentos de conhecimento e de comunicação, eles tornam possivel o consensus acerca do sentido do mundo social que contribui fundamentalmente para a reprodução da ordem social." (BOURDIEU, 1998: 9).

É nossa pretensão, analisar o discurso do idoso, através dos significados que ele dá para sua própria saúde, levando-se em conta toda a influência que a cultura exerce sobre sua maneira de pensar. Consideramos importante conhecermos quais os símbolos culturais de que o idoso se utiliza para se pensar e também interpretar a sua saúde.

Com a visão cultural desenvolvida, tendo como apoio os pensamentos de estudiosos, podemos articular nossa proposta. Entretanto, dependemos de estabelecer situações especificas, no que concerne às referências imediatas, como a saúde do idoso vista de forma mais abrangente.

Com essa perspectiva acima apontada, levando em conta especialmente a visão cultural, articulamos a presente proposta. Certamente entendemos que não é uma análise sobre a cultura em geral, sobre a visão cultu al do 
idoso sobre a sua saúde, mas estamos analisando idosos concretos da cidade de Bragança Paulista, Atibaia e assim sendo dependemos do estabelecimento de situações especificas que dizem respeito às referências imediatas como, por exemplo, explicitar alguns dados sobre a saúde do idoso no Brasil e no mundo. 


\subsection{A SAÚDE DO IDOSO}

A evidência primeira da velhice se dá no corpo. O corpo por si só não se revela como atributo à velhice, mas uma vez que ela, como estigma, se instala no corpo, passa a inquietar o idoso. Certamente, a inquietação é decorrente de uma avaliação também estigmatizada e, assim sendo, uma abominação do velho diante de seu próprio corpo. "A visão de um corpo imperfeito - "em declinio", "enfraquecido", "enrugado", "doente" não avalia só o corpo, mas sugere imediatamente ampliar-se para além do corpo, sobre a personalidade, o papel social, econômico e cultural". (MERCADANTE, 1997: 29). Isto não quer dizer que a velhice seja uma "doença", uma patologia. Sabemos que há indivíduos que em tenra idade contraem determinada doença e essa lhe acompanha por toda a vida, podendo se agravar com a chegada da velhice, mas não necessariamente. Portanto, essa imediata correlação entre velhice e doença não é verdadeira, mas faz parte também do modelo geral ideológico do velho

Hoje encontramos jovens que pelo mau hábito da alimentação, pelo sedentarismo, uso do fumo, drogas, álcool, já têm instalados em seus órgãos determinadas doenças e se ainda não se instalaram, esses jovens estão susceptiveis a desenvolverem determinadas patologias. (Organización Panamericana de La Salud, 1994: 90). 
Essa correlação entre velhice e doença nos leva a refletir sobre como a sociedade pensa a saúde do idoso. Assim Beauvoir mais uma vez nos esclarece quando diz:

"Muito longe de oferecer ao idoso um recurso, contra seu destino biológico assegurando-the um futuro póstumo, a sociedade de hoje o rechaça ainda vivo para um passado ultrapassado." (BEAUVOIR, 1990: 468).

Essa reflexão de Beauvoir é preciosa pois coloca o idoso como ser doente simplesmente pelo fato de ser idoso, assim sendo, idoso fica como sinônimo de doente.

Com o desejo de conhecer mais adequadamente o perfil de saúde dos idosos nos paises da América do Sul, a OPS coordenou um estudo sobre as necessidades dos idosos, isto na segunda metade da década de 80 . Um dos resultados apresentados é que uma porcentagem substancial dos participantes do estudo qualificou sua saúde como não muito boa. Isso devese ao fato de que as pessoas de idade avançada comparam sua saúde com a que tinham quando jovens $e$, em conseqüência, não a vêem de maneira positiva. (ORGANIZACIÓN PANAMERICANA DE LA SALUD, 1994: 98).

Outros estudos, bem como conferências se seguiram no sentido de promover a saúde do idoso.

É importante enfatizar que essa questão vem sendo estudada no Brasil, já se buscam caminhos para preservar a saúde de nossos idosos. É para eles 
que as politicas de manutenção da saúde e qualidade de vida devem estar voltadas, como forma de se evitar o surgimento de doenças, e a conseqüente perda da qualidade de vida.

"Face às raras politicas sociais voltadas para este grupo populacional, coube-lhe reinventar um novo modo de vida, construindo, assim, uma outra representação da velhice desvinculada dos atributos negativos que the são nomalmente atribuidos, como a inatividade e a decadência." (VERAS, 1997:32).

BRITO (1997), em sua tese de mestrado, também, ressalta que "o estado de saúde de um indivíduo é muito mais que um mero bem-estar físico. Ele se constitui numa complexa interrelação entre os aspectos psicológicos e fisiológicos da saúde e da doença, e também entre os componentes objetivos e subjetivos destes estados." (p. 12).

A maneira como um individuo acredita que seja a sua saúde é uma variável existente entre o estado objetivo da mesma e a aceitação ou rejeição subjetiva de sua condição de pessoa doente. Isso quer dizer que a interpretação que a pessoa faz de suas experiências de saúde ou estado precário da mesma, no contexto de sua vida diária, se baseia nas informaçōes e nos conhecimentos disponiveis, modificados pela experiência prévia e pelas normas sociais e culturais.

Entendemos como uma noção complexa aquela sobre saúde desenvolvida pela OMS. Saúde implica um estado completo de bem estar fisico, mental e social. Levar em conta o biológico, o social e o psíquico é 
ampliar a idéia de saúde e não reduzi-la a somente uma questão biológica pontual. A saúde não deve ser vista simplesmente como a ausência de doença ou enfermidade - é um direito humano fundamental, deve ser considerada como um recurso aplicável à vida cotidiana e não como objeto dessa vida. (Promoção da Saúde, Brasilia, 1996).

Aceitamos, por um lado, tal definição, porém se admitirmos como um suporte de verdade, criamos, por outro lado, uma condição de dificuldade efetivamente para medir a saúde das pessoas. Ao apontar para essa questão estou me remetendo aos meus entrevistados. Assim, verificamos que saúde não está especificamente atrelada a um completo bem estar físico, mental e social. Pode-se ter saúde dentro de outras derivadas, com limites menos rígidos.

No caso dos idosos, a aplicação desses conceitos torna-se mais difícil, pois essas medidas sofrem a interferência de atitudes culturais preconceituosas relativas ao envelhecimento. Além disso, as deficiências que não provocam incapacidades são pouco consideradas na assistência aos idosos, pois o que importa é a restauração ou a conservação da autonomia e da indepéndência. A autonomia se constitui em um indicador representativo de saúde (OMS; 1984), quando se refere ao estado de saúde de um individuo idoso. No entanto, essa autonomia deverá ser avaliada dentro de uma mesma cultura, face à ampla variedade de restrições políticas, sociais e econômicas das pessoas de todas as idades e em diferentes sociedades 
Apoiamos nos argumentos de Bourdieu (1998), para entendermos que a autonomia referida pelos idosos é um "poder simbólico", ela entra nas interações da vida cotidiana, podendo ser aceita (com resignação ou submissão) ou propondo estratégias de dissimulação, a imagem de si o menos afastada possivel da identidade legítima. (p. 124).

"Embora seja necessário e importante obter informações na área especifica da saúde, o funcionamento de uma área tem um impacto direto no funcionamento de outras. Portanto, estado econômico, bem estar social, saúde física, saúde mental e desempenho das atividades da vida diária (AVD), estão intimamente interligadas, sendo que esta relação aumenta como avançar da idade do individuo." (BRITO, 1997: 19).

As dificuldades referidas pelos individuos idosos não estão sempre associadas às doenças. "Os familiares, amigos e, freqüentemente, mesmo os profissionais de saúde, tendem a interpretar como sendo de natureza médica os problemas apresentados pelos velhos. No entanto, esses estão inclinados a falarem sobre suas frustrações a propósito de suas incapacidades de fazerem algo que eles gostariam de fazer. Os idosos raramente dizem que estão preocupados com a sua saúde, levando a acreditar que o objetivo principal da maioria deles é se manterem, ou se tornarem independentes". (WHO, 1981)

Na Primeira Conferência Internacional sobre a Promoção da Saúde, realizada em Ottawa - Canadá, encontramos como pré-requisitos para a saúde a moradia, a alimentação, lazer e acesso a serviços de saúde, paz, 
segurança social, justiça social, educação, meio ambiente e liberdade. (Promoção da Saúde, 1996 :37)

Ainda a carta de Ottawa preconiza que:

"... a melhoria de saúde requer alcançar um nível satisfatório nestes aspectos fundamentais, mas supõe também, dispor de informações e habilidades pessoais, bem como condições que favoreçam a saúde nas questões econômicos, sociais e físicas." (p. 38).

Quando examinamos mais de perto o sentido dessa "improdutividade" atribuida ao velho, que acaba por torná-lo alvo secundário das práticas de saúde, observamos que ai reside o eixo central das conotações negativas do Ser Velho em nossa sociedade. Em realidade, é essa "improdutividade" e o que ela representa, ampliada em termos sociais e psiquicos, como impotente, não criativo, declinante, que dá o sentido definitivo e inexorável da velhice em nossa cultura. Nesse sentido, a negatividade da velhice é de ordem similar à negatividade do estar doente, isto é, do estar incapaz para trabalhar, não só no sentido econômico mas também social, com a diferença que, ao contrário dessa última condição, aquela praticamente não possui capacidade de "recuperação" e, portanto, de reinserção na produção e na sociedade. Tal diferença expressa-se na escolha dos termos que nomeiam essas condições: ser velho e estar doente, denotando a irreversibilidade da primeira e a provisoriedade dessa última condição. (O verbo ser expressa estado permanente e estar estado provisório). 
A Organização Pan-Americana da Saúde (OPAS), em sua 25a Conferência Sanitária Pan-Americana, 1998, considera que a saúde na terceira idade é determinada, em alto grau, pelos padrões de vida, pela exposição e pelas oportunidades de proteção e promoção da saúde no curso da vida. A capacidade de acesso a uma atenção de saúde geral de alta qualidade acusa substanciais diferenças de uma para outra camada socioeconômica. Sem estratégias nacionais para equacionar cada um desses fatores com eqüidade, as desigualdades quanto à qualidade de vida e bem-estar dos mais velhos de diferentes classes socieconômicas se tornarão ainda maiores na velhice.

No mesmo documento, a OPAS, baseia-se no pressuposto de que o envelhecimento bem sucedido é aquele que se dá sem doenças, como também ausência, presença ou gravidade de fatores de risco depende muito da prevenção de doenças e deficiências, da manutenção de altas funções físicas e cognitivas e da participação constante em atividades sociais e produtivas. O envelhecimento bem-sucedido requer ênfase na educação durante toda a vida, o uso criativo das experiências de vida e politicas que incentivem a utilização de trabalhadores mais velhos. Há necessidade de programas de preparação para a aposentadoria, tanto como de políticas nacionais que assegurem um minimo aceitável de segurança financeira para os idosos aposentados ou desempregados.

Os programas devem oferecer um espaço em que a reformulação de padrões tradicionais de envelhecimento possa ser uma experiência cr 'etiva 
e no qual participar deles ativamente signifique viver intensamente uma nova etapa da vida, um momento próprio para exploração da identidade e de novas formas de auto-expressão. (FERRARI, 1999: 197).

A capacidade de recuperação durante a vida é ingrediente essencial para o envelhecimento bem-sucedido. Esse conceito refere-se à capacidade do individuo de se recuperar das perdas, eventos que provocam estresse e doenças que muitas vezes acompanham o processo de envelhecimento'.

Ainda a OPAS em sua $25^{\mathrm{a}}$ Conferência Sanitária Pan-Americana (1998) propõe Estratégias Regionais para o Envelhecimento Sadio e o Desenvolvimento para o periodo de 1990-2002. Vê como alguns parceiros importantes, para início das atividades nos países e para gerar investimentos de recursos humanos e financeiros no nivel nacional, instituições como os ministérios da Saúde, do Trabalho, da Previdência Social, da Justiça, da Educação e da Seguridade Social, os governos locais, as ONGs que atuam diretamente com os idosos, as Universidades e Institutos de Pesquisa, as organizaçōes de aposentados, os veículos de divulgação, as companhias de seguros e outras organizaçōes do setor privado que trabalham com os idosos.

Os anos 70 marcaram o advento, no Brasil, das preocupações com o crescente aumento da parcela da população que atinge e supera os 60 anos (IBGE; 1980). A realização de seminários regionais, sob o patrocínio do

\footnotetext{
${ }^{1}$ Saúde dos Idosos: Envelhecimento e Saúde: Um novo Paradigma 25a Conferência Sanitária Pan-Americana, D.C. 21-25 setembro 1998, p.10
} 
Ministério da Previdência Social - MPAS - SAS, representou uma tomada de decisão diante do fato de que ao governo cabe identificar os problemas de ordem pública e, a partir dai, fixar objetivos a curto e longo prazos, quando se verifica estar sendo afetado qualquer segmento da população.

Recentemente, a partir de 1992, o envelhecimento populacional passou a integrar a agenda de discussão e encaminhamento de políticas públicas, no Brasil, citadas a seguir. Isto se deve à percepção de que essa população está crescendo muito rapidamente e suas necessidades precisam ser olhadas com atenção.

Essas politicas estão expressas na lei $n^{\circ} 8842 / 94$, no âmbito federal e na lei 9892/97, no âmbito do Estado de São Paulo bem como em iniciativas de atenção à saúde da população idosa no âmbito do municipio, consoante o que dispõe o Programa de Atenção à Saúde do Idoso elaborado pela Secretaria Municipal da Saúde em 1998, que visa à "Assistência integral à população idosa do município", bem como o desenvolvimento de programas voltados à promoção de saúde, à prevenção e ao controle de doenças e incapacidade que acometem a população idosa. No entanto, essas políticas estão expressas somente em forma de leis, na prática muito pouco tem-se feito para atender às reais necessidades do idoso a nivel de poder público. A maior atuação se dá a nivel de instituições não governamentais.

No nosso pais, há bem pouco tempo, o idoso só chamava a atenção da imprensa (jornais, revistas, rádio, televisão) para destacar raridades ou 
curiosidades, como o homem "mais velho", a mulher "mais velha" do mundo; "velhinho de oitenta anos se casa com moça de vinte" ou ainda, "pai aos oitenta anos" e outras banalidades ou excentricidades do gênero, numa clara visão de que esta população parecia não ter o direito de participar da vida cotidiana. (GOLDMAN, 1999: 23).

Hoje essa visão está se modificando a partir do momento em que o contingente de idosos está se revelando como uma faixa de consumo rentável, algumas iniciativas em publicidade e nos demais meios de comunicação de massa têm apresentado um enfoque mais respeitoso em relação ao idoso.

O "boom" de idosos segue curso previsivel: de cerca de sete milhōes de pessoas com mais de 60 anos em 1980, o censo de 1991 já registrou quase onze milhões, caminhando-se para trinta e dois ou trinta e três milhões no ano de 2025 (IBGE; 1991).

Os resultados parciais do Censo de 1991 indicam para o Brasil a proporção de $7,3 \%$ de idosos. A proporção de idosos com 80 anos e mais, chegou em 1991 a 10,6\% do grupo populacional de 60 anos e mais (IBGE; 1991). Os dados do Censo de 2000 ainda não foram publicados mas procuramos levantar os dados parciais, em 1/11/2000, e esses apontam para uma população de 14 milhōes de idosos no país. (IBGE, 2000) 
Para compreender esses dados, há necessidade de observarmos as transformações que vêm ocorrendo na dinâmica demográfica brasileira transição demográfica - de forma bastante resumida é:

"10) A natalidade permanece alta e a mortalidade inicia um descenso.

$\left.2^{\circ}\right)$ A mortalidade continua a cair e a natalidade inicia uma fase decrescente.

30) A natalidade e a mortalidade se aproximam em niveis consideravelmente mais baixos." (CAMARGO e SAAD, 1990: 9).

No caso do Brasil, estariamos na segunda etapa da transição demográfica.

$\mathrm{Na}$ realidade brasileira, envolvida em contínuas e progressivas crises econômico-sociais, o aumento da população idosa torna-se um problema,

“.. como absorver e lidar com as necessidades dos idosos quando as prionidades estão claramente relacionadas a outros grupos etánios da população. Quanto maior o número de pessoas que envelhece, maior a necessidade de recursos para atender as suas necessidades especificas." (KALACHE et al, 1987: 206).

Sabe-se que o processo de envelhecimento tem impacto significativo sobre diversas dimensões do desenvolvimento e do funcionamento das sociedades, bem como sobre o bem-estar relativo, não só dos idosos, como também das populações mais jovens. (FERRARI, 1999: 200).

É um direito do idoso ter saúde, viver em condições de vida saudável, ou seja, é seu direito "viver bem". Mas o que significa isso? 
No Brasil, a atenção à saúde da população idosa tem se manifestado, até o momento, por meio de iniciativas oficiais, que levam em consideração estudos realizados no exterior e conselhos de organizações internacionais

Segundo Nutbeam (1996):

"El concepto de promoción de la salud está en fase de desarrollo y no cabe duda de que será objeto de ulteriores mejoras." (p. 383).

"Se nos paises desenvolvidos o processo de envelhecimento da população ocorreu gradualmente e foi acompanhado de perto pelo Estado, principalmente a partir dos anos 30, com a implantação de medidas legais e sociais, no Brasil esse mesmo processo se apresenta em tênue progressão e desponta num momento de profunda crise econômica, onde o Estado deixa bem claro sua incapacidade em hastear essa bandeira." (VERAS, 1997:33).

Debert nos mostra que:

"A transformação da velhice em um problema social põe em jogo múltiplas dimensões que vão desde as iniciativas voltadas para propostas de formas de bem-estar que deveriam acompanhar 0 avanço das idades, até empreendimentos voltados para o cálculo dos custos financeiros que envelhecimento da população trará para a contabilidade nacional". (DEBERT, 1996:35).

Torna-se evidente que o idoso representa um alto custo para as instituições públicas e privadas. Os planos de saúde tornam-se 
extremamente caros a partir do momento em que o indivíduo entra na faixa etária, estabelecida normalmente por eles, 50 anos.

Com isso passa-se a atribuir ao idoso a responsabilidade de manter-se bem, com saúde, fora das instituições asilares, vivendo em um ambiente saudável e mostrando-se ativo e envolvido com o mundo. Cabendo, portanto, aos idosos programarem para si mesmos uma existência longeva e ativa. (GOLDMAN, 1999: 62)

Na I Conferência Internacional sobre Promoção da Saúde, realizada em Otawa, Canadá, em 1986, a questão relativa à promoção da saúde surgiu como um paradigma alternativo aos problemas de saúde dos paises. Ela é conceituada assim:

"Promoção da saúde é o nome dado ao processo de capacitação da comunidade para atuar na melhoria da sua qualidade de vida e saúde, incluindo uma maior participação no controle deste processo. Para atingir um estado de completo bemestar físico, mental e social, os individuos e grupos devem saber identificar aspirações, satisfazer necessidades e modificar favoravelmente o meio ambiente. A saúde deve ser vista como um recurso para a vida, e não como as capacidades físicas. A promoção da saúde não é responsabilidade exclusiva do setor saúde, e vai para além de um estilo de vida saudável, na direção de um bem-estar global." (Promoção da Saúde, 1996: 6).

O documento atribui o papel de protagonista a homens e mulheres, como sendo capazes de controlar fatores determinantes da sua saúde. $O$ desenvolvimento social, econômico e pessoal são dimensões consideradas 
importantes da qualidade de vida. Aqui estão as raízes do tão propagado incentivo ao autocuidado na velhice, apregoado nas práticas atuais da saúde, sem, contudo. culpar as pessoas que adoecem, tornando a doença uma responsabilidade unicamente individual.

Cinco campos de ação foram preconizados:

- elaboração e implementação de políticas de saúde;

- criação de ambientes favoráveis à saúde;

- reforço da ação comunitária;

- desenvolvimento de habilidades pessoais e

- reorientação dos sistemas e serviços de saúde.

A Declaraçăo de Adelaide (Austrália; 1988), manteve a direção estabelecida nas Conferências de Alma-Ata (1978) e Ottawa:

"As politicas públicas saudáveis caractenzam-se pelo interesse e preocupação explícitos de todas as áreas das politicas públicas em relação à saúde e à eqüidade, e pelos compromissos com o impacto de tais politicas sobre a saúde da população. O principal propósito de uma politica pública saudável é criar um ambiente favorável, para que as pessoas possam viver saudáveis. As politicas saudáveis facilitam opções saudáveis de vida para os cidadãos. Criam ambientes sociais e físicos comprometidos com a saúde. Para formular politicas públicas saudáveis, os setores govemamentais de agricultura, comércio, educação, indústria e comunicação devem levar em consideração a saúde como um fator essencial." (Promoção da Saúde. 1996: 37).

A III Conferência Internacional sobre Promoção da Saúde: Ambientes Favoráveis à Saúde (Sundsvall. Suécia, 1991) traz o tema do meio ambiente 
incorporado à área da saúde. Essa conferência reconhece o papel de todos na criação de ambientes favoráveis e promotores da saúde, salientando as dimensões social, econômica, política e cultural na promoção da saúde:

"Ambientes e saúde são interdependentes e inseparáveis Atingir estas duas metas deve ser o objetivo central ao se estabelecer prioridades para o desenvolvimento e devem ter precedência no gerenciamento diário das politicas govemamentais." (Promoção da Saúde, 1996: 8).

Essa visão global de saúde é imprescindivel para se pensar as especificidades do processo de envelhecimento e como é essencial uma abordagem multifatorial desse tema.

Também, em 1992, realizou-se a Conferência Internacional da Promoção da Saúde (Santafé de Bogotá, Colômbia), respondendo à problemática especifica das nações latino-americanas e incorporando aspectos significativos das reuniões anteriores e da experiência de outras nações do mundo.

"A promoção da saúde na América Latina busca a criação de condições que garantam o bem-estar geral como propósito fundamental do desenvolvimento, assumindo a relação de mútua determinação entre saúde e desenvolvimento [...] o desafio da promoção da saúde na América Latina consiste em transformar as relações excludentes, conciliando os interesses econômicos e os propósitos sociais de bem-estar para todos, assim como em trabalhar pela solidariedade e a eqüidade social, condições indispensáveis para a saúde e o desenvolvimento. "(Promoção da Saúde, 1996:8). 
No segundo item, da mesma declaração da Conferência Internacional da Promoção da Saúde, a participação popular é enfatizada na administração das decisões de saúde, onde a inquietação reitera a necessidade de alternativas novas para combater o sofrimento causado pelas doenças do atraso e da pobreza:

"Nesse sentido, a divulgação de informações e a promoção do conhecimento constitui em valiosos instrumentos para a participação e para as mudanças de estilos de vida das comunidades." (1996: p. 43).

A deterioração das condiçōes de vida das populações na América Latina, aliada à redução de recursos necessários para promover a saúde, são representados nesta conferência como o principal desafio do continente. Atribui-se à promoção de saúde não só o papel de identificar os fatores que favorecem à iniqüidade, mas também o de atuar como agente de mudança nas atitudes e condutas da população e de seus dirigentes. A reorientação dos serviços de saúde implica mais pesquisas na área e, mudanças na educação, especialmente no que toca a formação e 0 treinamento de profissionais da saúde.

Interessa aqui destacar particularmente a importância do atendimento que deverá ser fornecido à população idosa, no conjunto das demandas dos paises emergentes. $O$ envelhecimento não mais se restringe a poucos individuos, mas está cada vez mais presente na vida social. 
Ressaltamos mais uma vez que além de "bem-estar" não implicar ausência total de enfermidades, o uso desse termo tampouco leva em consideração os mecanismos de alterações estruturais e fisiológicas adaptativos do organismo ao seu meio ambiente. Para alcançar um estado adequado de bem-estar físico, mental e social, um grupo deve ser capaz do identificar e realizar suas aspirações, satisfazer suas necessidades e mudar ou adaptar-se ao meio ambiente. Portanto, o conceito de saúde como bemestar transcende a idéia de formas de vida sadias. (Promoção da Saúde, 1996: 37)

"No Brasil, o processo de envelhecimento se deu muito rápido e surge num momento de crise económica em que as desigualdades e os problemas sociais parecem recrudescer." (FERRARI, 1999:201).

Acreditamos que para atender este contingente que ai está, necessário foi se reestruturar os programas de atenção à saúde

O Plano de Ação Governamental Integrado para o Desenvolvimento da Politica Nacional do Idoso (1996) pretendeu ser um documento norteador das ações, de forma descentralizada, a serem desenvolvidas por intermédio dos órgãos setoriais nos Estados e municipios, em parceria com as organizações governamentais e não-governamentais. (p.5)

"A ausência de condições de apoio familiar, a pobreza material e a inexistência de programas e serviços de instituições sociais fazem com que os idosos ingressem na tão conhecida marginalidade social. acentuando as fragilidades naturais to 
envelhecimento." (Plano de ação govemamental integrado para o Desenvolvimento da Política Nacional do Idoso, 1996: p. 8)

Manter o idoso fora do ambiente institucional faz parte da recomendação do documento, que salienta a necessidade de investimento em outros modelos de intervenção com custos menores e melhores resultados sociais.

O Seminário Internacional Envelhecimento Populacional: uma agenda para o final do século, realizado em Brasilia em julho de 1996, culminou com a formulação do decreto 1948 , regulamentando a Lei $n^{\circ} 8842 / 94$, dispondo sobre a política nacional do idoso e buscando uma tradução dessa política em termos de um plano de ações para o idoso no Brasil.

No entanto, somente em 1998, um grupo de profissionais de vários estados, com inserção, nas Instituições de Ensino Superior e de técnicos do Ministério da Saúde, foram convocados, através da Secretaria de Políticas de Saúde do Ministério da Saúde, a elaborarem a Política Nacional de Saúde do Idoso (PNSI).

$\dot{E}$ importante considerar que as necessidades de saúde dos idosos requerem uma atenção especifica que pode evitar altos custos para o Sistema de Saúde e, sobretudo, proporcionar melhores condições de saúde a essas pessoas. O objetivo desta politica é permitir um envelhecimento saudável, o que significa preservar a sua capacidade funcional, a sua autonomia e manter o nivel de qualidade de vida. (Plano de Ação Governamental Integrado para o Desenvolvimento da Política Nacional do Idoso, 1996: 8). 
A PNSI, instrumento de que o setor saúde passa a dispor, estabelece as diretrizes essenciais que norteiam a definição ou redefinição dos programas, planos, projetos e atividades do setor na atenção integral às pessoas em processo de envelhecimento e à população idosa (integrada pelos individuos com 60 anos de idade ou mais, de acordo com a Lei $\left.n^{\circ} 8842 / 94\right)$. Essas diretrizes são:

- a promoção do envelhecimento saudável;

- a manutenção da capacidade funcional;

- a assistência às necessidades de saúde do idoso;

- a reabilitação da capacidade funcional comprometida;

- a capacitação de recursos humanos;

- o apoio ao desenvolvimento de cuidados informais;

- e o apoio a estudos e pesquisas.

O processo de elaboração da PNSI ocorreu de forma participativa, segundo os organizadores, através de amplas discussões do grupo de redatores com os vários segmentos representativos do meio gerontológico brasileiro, em um processo democrático que certamente agregou credibilidade à politica formulada. (Plano de Ação Governamental Integrado para o Desenvolvimento da Política Nacional do Idoso, 1996: 5).

No entanto, o caminho inverso não foi percorrido, isto é, não se buscou na fala dos próprios idosos os subsidios para o planejamento e implementação desta política 
Como explica Geertz (1989):

"A cultura apresenta-se como sistemas entrelaçados de signos interpretáveis. Descobrir os significados implica no estabelecimento de um contato mais próximo entre pesquisador e pesquisado, e na possibilidade de um diálogo entre os mesmos". (p.24).

Voltando ao processo de elaboração da PNSI só após meses de trabalho foi produzido um primeiro texto, sendo este, submetido à apreciação em uma Oficina, realizada na Organização Pan-Americana da Saúde, em Brasilia, nos dias 22 e 23 de abril de 1999. O processo de correções e ajustes, advindos da Oficina, deu margem à elaboração de uma nova versão do texto, submetido e aprovado na $7^{a}$ Reunião Ordinária da Comissão Intergestores Tripartite, em 16/09/1999. O novo texto foi então submetido, no dia 11/11/1999, à instância máxima do Ministério da Saúde, na $92^{\circ}$ Reuniāo Ordinária do Conselho Nacional de Saúde, onde foi aprovado, por unanimidade pelos conselheiros

Após percorrer esses caminhos, a Política Nacional de Saúde do Idoso foi promulgada pelo Sr. Ministro da Saúde (portaria no 1395, de 9 de dezembro de 1999).

Preconiza-se que o apoio informal familiar constitui um dos aspectos fundamentais na atenção à saúde do idoso. Isso não significa, no entanto, que o Estado deixe de ter um papel preponderante na promoção, proteção e recuperação da saúde do idoso nos três niveis de gestão do SUS (Sistema 
Único de Saúde), papel este capaz de otimizar o suporte familiar sem transferir para a familia a responsabilidade em relação a este grupo populacional. (Promoção da Saúde, 1996: 35)

A maior parte dos idosos é, na verdade, absolutamente capaz de decidir sobre seus interesses e de se organizar, sem necessidade de ajuda de quem quer que seja. Esse idoso que mantém sua autodeterminação e prescinde de qualquer ajuda ou supervisão para agir no seu cotidiano deve ser considerado um idoso saudável, ainda quando portador de uma doença crônica, essa não o torna incapaz, uma vez que ele já aprendeu a conviver com ela.

"A presença de uma doença crônica não significa que o idoso não possa genir sua própria vida e viver o seu dia-a-dia de forma independente." (GORDILHO, 2000: 20).

A permanência no meio em que vivem, o exercicio de forma independente de suas funções na sociedade devem ser garantidos pelo Estado brasileiro.

Chamar a atenção para a questão do idoso, do envelhecimento é uma questão pública, de saúde pública e, por isso, a presente discussão se insere na "Faculdade de Saúde Pública", pois não é uma questão privada, ou restrita ao consultório médico.

Decorre dai o conceito de capacidade funcional, ou seja, a capacidade de manter as habilidades fisicas e mentais necessárias a uma vida independente e autônoma. Do ponto de vista da saúde pública, a 
capacidade funcional surge como um novo conceito de saúde, mais adequado para instrumentalizar e operacionalizar a atenção à saúde do idoso. (GORDILHO, 2000: 20).

Por isso a saúde pública se fundamenta numa visão complexa de envelhecimento e saúde, busca a promoção do envelhecimento saudável e a manutenção pelo maior tempo possivel da máxima capacidade funcional do individuo que envelhece. A saúde pública promove tudo isso a favor do envelhecimento saudável, no entanto, ela não ouve os velhos. 


\subsection{OS SIGNIFICADOS DA SAÚDE PARA O IDOSO}

Ao analisarmos a preocupação dos grupos internacionais sobre a saúde do idoso, através dos vários documentos produzidos em OTTAWA (1986), ADELAIDE (1988), SUNDSVALL (1991), BOGOTÁ (1992) e JACARTA (1997), com a participação do Brasil, através de seus representantes do Ministério da Saúde e da Previdência Social, inferimos que a saúde do idoso no Brasil está condicionada aos princípios de ação comum: concentrar a atenção na promoção da saúde e na minimização da dependência dos idosos. Esses devem ser considerados participantes ativos na sociedade. (OPS, 1998:1).

Os parâmetros usados para a discussão e conseqüentes conclusões que norteiam os documentos internacionais e nacionais, têm como fundamento uma avaliação das condições estabelecidas culturalmente. (OPS, 1998:3). Tais parâmetros, por sua vez, não levam em conta a visão do próprio idoso sobre essas questões. Isto nos chamou a atenção e leva-nos à análise do significado de saúde para o idoso

A maneira como o idoso olha para si mesmo vai ser influenciada pela cultura de que ele faz parte, pela maneira como vive e vem vivendo e pelas relações sociais que são estabelecidas.

Para o idoso, saúde è um instrumento que tem como significado a continuação de sua vida, é sentir que algo dentro de si mesmo está indo 
bem, seria a capacidade pela qual possa desempenhar suas atividades como gostaria de fazê-las. (FERRARI, 1999: 197).

Os idosos podem se apresentar melancólicos e pessimistas, quando se deparam com a perda da auto-estima, com a perda do papel social a que estavam submetidos. Na verdade, em uma sociedade marcadamente materialista, individualista e utilitarista como a nossa, a perda do poder ou do saber pode ser vista como uma verdadeira catástrofe pessoal. $\dot{E}$ importante ainda considerar que os idosos, vitimas dessa mentalidade, também a possuem, sendo freqüentemente materialistas e individualistas, o que agrava ainda mais a perda da auto-estima e a carga de pessimismo. (VERAS, 1997: 44).

"A tendência de toda sociedade é viver, é sobreviver, exalta o vigor e a fecundidade associados à juventude: teme o desgaste e a esterilidade da velhice." (BEAUVOIR, 1976:44).

É muito comum, ouvirmos idosos queixarem-se de que, após a aposentadoria ou após os filhos terem se casado e mudado de casa, a memória começou a falhar. Se dizem doentes da cabeça. Nestes casos, o que sucede é que eles não estão mais acostumados a se utilizar de uma série de recursos de apoio à memória tornando-se menos hábeis em arquivar fatos. Os idosos que mantêm uma atividade intelectual intensa, têm memória melhor do que aqueles que se encontram inativos. Esse fato, é de conhecimento milenar. O grande pensador romano Marco Túlio Cícero² escreveu sobre a velhice (De Senectute)e diz o seguinte: "A única maneira

\footnotetext{
${ }^{2}$ Marco Túlio Cicero, nasceu em Arpinum em 106 a.C. Morreu em Fórmia em 43 a.C
} 
de um idoso manter boa memória é usar recursos de treinamento esforçando-se para relembrar uma lista de nomes, ou procurando dizer, ao final de cada dia, tudo o que fez desde a manhã. Talvez o melhor remédio para manter ou recuperar a memória seja usá-la e treiná-la, tanto através de atividades culturais quanto de jogos que facilitam o desenvolvimento da memória, como palavras cruzadas, xadrez ou bridge." (LEME, 1997: 36).

Embora o idoso não esteja sentindo necessidade de lembrar fatos, a excessiva cobrança da sociedade sobre ele faz com que o mesmo lembre constantemente de fatos desnecessários ao momento. Decorre disso o dever de o idoso mostrar-se saudável e ativo, para não ser considerado inútil e conseqüentemente ser envolvido naqueles fatos.

Segundo, Simone de Beauvoir:

"Para se defender contra uma inércia nefasta em todos os sentidos, o velho precisa se manter ativo: seja qual fôr a natureza desta atividade, o conjunto de suas funções será melhorado." (1976; 305).

Encontrar ocupações para o idoso, torna-se uma questão de fundamental importância. Não só mentalmente mas numa cultura consumista como analisa Debert fundamentando-se diretamente em Featherstone (1992), o corpo do idoso deve ser autopreservado. Com esta idéia, os "individuos adotam estratégias instrumentais para combater a deterioração e a decadência. Dai a noção de que o corpo é um veículo do prazer e da auto expressão". (DEBERT, 1996: 38). 
Debert, ainda fundamentada nas colocações de Featherstone diz:

"A publicidade, os manuais de auto-ajuda e as receitas dos especialistas em saúde estão empenhados em mostrar que as imperfeições do corpo não são naturais nem imutáveis, e que, com esforço e trabalho corporal disciplinado, pode-se conquistar a aparência desejada, as rugas ou a flacidez se transformam em indicios de lassitude moral e devem ser tratadas com a ajuda dos cosméticos, de ginástica, das vitaminas". (DEBERT, 1996: 37).

Os individuos mais uma vez são chamados a exercer uma vigilância sobre seu corpo e a se responsabilizarem por sua própria saúde. São estimulados a fazerem exercicios fisicos, caminhadas, balancearem a alimentação, procurarem os cirurgiões plásticos para realizarem algumas plásticas, tudo no sentido de manterem o corpo em forma. Autores como Beauvoir, De Masi avaliam essa questão das seguintes formas:

Segundo Beauvoir (1976):

"Quanto mais elevado o nivel intelectual do individuo, mais ricas e variadas permanecerão suas atividades. A inatividade provoca uma apatia que mata qualquer desejo de atividade." (p. 306)

A sociedade determina o lugar e o papel do idoso. O individuo é condicionado pela atitude prática e ideológica da sociedade a seu respeito

Bem como aponta De Masi (2000):

"Um número enorme de pessoas vive em contextos urbano-industriais e introjetam seus ritmos e valores. A grande maioria das pessoas não sabem como se distrair nem como descansar." (p.313). 
O que ocorre mais comumente é a dificuldade persistente, constante, reexperimentada, de apreender certos aspectos da natureza, de si mesmo e da sociedade, de trazer certos fenômenos esquivos para a esfera dos fatos culturalmente formuláveis que tornam o homem cronicamente inquieto, dirigindo para eles um fluxo mais uniforme de símbolos de diagnóstico.

Geertz, citando Schutz indica que:

"O que distingue o senso comum como um modo de "ver" é a simples aceitação do mundo, dos seus objetos e dos seus processos exatamente como se apresentam, como parecem ser." (SCHUTZ apud GEERTZ, 1989: 134)

O mundo cotidiano de objetos de senso comum e de atos práticos, como diz Geertz, "é que constitui a realidade capital da experiência humana-capital no sentido de ser este o mundo no qual estamos solidamente enraizados, cuja inerente realidade pouco podemos questionar (por mais que possamos questionar certas porções dela) e de cuja pressões e exigências raramente podemos escapar." (id. ibid, p.135).

O homem necessita de padrões culturais para regulá-lo, não existe natureza humana independente da cultura:

"Não dingido por padrões culturais - sistemas organizados de simbolos significantes - o comportamento do homem seria virtualmente ingovemável, um simples caos de atos sem sentido e de explosões emocionais, e sua experiência não teria praticamente qualquer forma. A cultura. a totalidade acumulada de tais padrões, não é apenas um ornamento da existência humana. 
mas uma condição essencial para ela - a principal base de sua especificidade." (GEERTZ, 1989:58).

O mesmo autor afirma que: "no homem as emoções fazem parte dos artefatos culturais, a preocupação de esclarecer os significados que não são transparentes no discurso, envolve necessariamente os sentimentos". (id. ibid, p.313).

Quando abordamos os idosos a respeito do significado de sua saúde estamos aprofundando significados, incorporando explicações adquiridas através dos sentimentos, das suas vivências, do seu cotidiano.

"Os significados se processam e se transformam através de atividades e pensamentos de indivíduos concretos e assim se subjetivam (adquirindo um sentido pessoal) na medida em que retornam para a objetividade sensorial do mundo que os cerca, através das ações que eles desenvolvem concretamente." (LANE, 1984: 22).

Ao determo-nos nos significados expressos pelos idosos sobre suas experiências, descobrimos certos determinantes sobre as situações e sobre o sujeito. O sujeito é tido como um atribuidor de significados e não um repetidor de idéias mecanicamente adquiridas. (LANE, 1984: 23).

Os dados obtidos são as situações vividas que foram conscientemente tematizadas pelo sujeito. Os significados são os aspectos do evento que o sujeito tematizou 
A forma mais adequada para apreender os significados é procurar descobrir a realidade investigada tal como experienciada pelo sujeito, a qual é exposta nas suas descrições. (LANE, 1984: 23).

Supõe-se que o significado expresso pelos idosos sobre sua saúde podem variar de sujeito para sujeito e, assim, nos defrontaremos com um conjunto de significados, ou seja, a circulação do conhecimento e das idéias pertencentes a um subgrupo que se encontram em contato mais ou menos estreito. Complementando essa idéia temos a análise de Debert que diz "Essas são representações emancipadas com um certo grau de autonomia em relação aos segmentos interagentes da sociedade. Elas têm uma função complementar na medida em que resultam do intercâmbio e partilha de um conjunto de interpretações ou símbolos." (DEBERT, 1988:63).

Buscando compreender essa dinâmica de significados, procuro conhecer como o idoso vê a sua própria saúde e como ele a define, valendo-me da proximidade com o grupo nas relações estabelecidas entre professor/ aluno. A resposta a essas colocações me levará à representação social deste subgrupo, idosos que freqüentam a Universidade para a Terceira Idade.

Essas representações são aqui abordadas como construções do sujeito. pensado enquanto sujeito social.

De forma mais geral, as representações designam uma forma de pensamento social. Podem ser entendidas como idéias, imagens 
concepções e visões do mundo (MOREIRA e OLIVEIRA, 1998) ou seja, as maneiras com que os sujeitos se relacionam com o mundo à sua volta.

“... são modalidades de pensamento prático orientadas, para a comunicaçăo, a compreensão e o domínio do ambiente social, material e ideal. Enquanto tais, elas apresentam caracteristicas específicas no plano da organização dos conteúdos, das operações mentais e da lógica. A marcação social dos conteúdos ou dos processos de representação refere-se às condições e aos contextos nos quais emergem as representações, às comunicações pelas quais circulam, às funções que elas servem na interação com o mundo e com os outros. " (SÁ, 1996: 33).

Pode-se dizer, a partir de Sá (1996), que o ponto de partida para compreender as representações que os idosos fazem ao expressar o significado de sua própria saúde será a avaliação de seu próprio "olhar" numa perspectiva fenomenológica, tendo em vista que:

"A reflexão fenomenológica vai em direção ao "mundo da vida", ao mundo da vivência cotidiana imediata, na qual todos nós vivemos, temos aspirações e agimos, sentindo-nos ora satisfeitos e ora contraniados." (FORGHIERI, 1990: p.18).

A fenomenologia traz aquilo que é impessoal para o pessoal, a história com o cotidiano dos sujeitos. "A significância particular está dentro de cada um de nós. O curso do tempo deve ser em primeiro lugar não apenas um presente que passa e constitui um passado mas, também, um futuro que pressiona o presente". (MARTINS, 1998:16). 
Acreditamos que a compreensão do mundo se dá a partir de um estoque de experiências pessoais e de outros. Assim o mundo do dia-a-dia é entendido como um tecido de significados, instituido pelas ações humanas e passivel de ser captado e interpretado. (GUARESCHI, 1999).

Nas vivências cotidianas, no dia-a-dia de cada um, o relacionamento com as pessoas permite trocas que levam em consideração as experiências passadas, as atuais e as perspectivas futuras, sem perder a maneira própria de cada um perceber e compreender suas necessidades. Nas interações, as necessidades de cada um podem ser transmitidas através da linguagem ou por atitudes não verbais como o olhar, os movimentos corporais ou a simples mudez. (SÁ, 1996: 34). Tudo isto nos mostrará o significado que o idoso dá para sua saúde.

$\dot{E}$ importante destacar que cada grupo social elabora representações conforme a posição que ocupa no conjunto da sociedade. Essas representações emergem de seus interesses especificos e da própria dinâmica da vida cotidiana com as mais diferentes formas de comunicação que ocorrem incessantemente. (MOREIRA e OLIVEIRA, 1998). A teoria das representações sociais vem possibilitar um olhar comum de estudiosos de diferentes áreas sobre diferentes objetos.

A partir do momento que o idoso volta o olhar para si mesmo, o conhecimento do corpo torna-se inseparável da sua compreensão como suporte ou condição para o exercicio de funções sociais e de sociabilidade: 
"corpo que corre, que anda, que trabalha, que pensa, que escreve, que dirige automóvel, que ouve música, que dança, que ri, que chora, que brinca." (LEFÈVRE, 1999: 78)

Explicitando essa idéia, temos a análise de Martins (1998) que diz: "Tenho um corpo e isto é inegável para qualquer um de nós. Somos nosso corpo e esta é minha essência. A importância de se conceber que somos esse corpo, e que somos nosso corpo, está no fato de que nossa existência pessoal é aberta, repousa num fundamento essencial adquirido e estabilizado". (p. 20)

Estar bem, é sentir o bom desempenho em algumas dessas ações, desses comportamentos. Essa concepção está ligada ao dinamismo, à atividade, ao lazer. Os idosos deixam de ser invisiveis, de ficarem restritos aos espaços privados e começam a invadir cada vez mais os espaços públicos. Isso os leva a criar estratégias de sociabilidade que thes permitem tecer novas relações sociais e fugir ao isolamento. (DEBERT, 1996: 37). A freqüência a lugares públicos induz à participação em novas atividades suscitando, assim, o sentimento de pertencer a um espaço e a um grupo caracterizado pela vontade de envelhecer ativamente, criando um novo emprego do tempo livre. (DE MASI, 2000: 304). Conquistando espaços de informação e sociabilidade, os idosos mudam a representação que thes é habitualmente imposta: a imagem de uma velhice monótona, sofrida. cheia de doenças, estereotipada perde aos poucos sua força e se desfaz, se transforma 
Percebemos que a idéia de promoção de saúde, de sentir um maior bemestar, de envelhecer saudavelmente está relacionada ao desenvolvimento de uma vida social, de um exercício de sociabilidade de cada indivíduo que é claramente proposto pelos documentos nacionais e internacionais, como tivemos oportunidade de analisá-los anteriormente.

Com o ensejo de contribuir para a mudança da imagem inativa do idoso, proporcionando-Ihe uma maior sociabilidade e um maior bem-estar, promovendo, assim um envelhecimento saudável, surgem a partir dos anos 60 os primeiros programas voltados para as pessoas idosas. O SESC implanta seus centros de convivência que estão espalhados por todo o território nacional e posteriormente, pelos anos 70 , surgem as Universidades Brasileiras da Terceira Idade, tanto nas Universidades públicas como nas privadas. (GOLDMAN, 1999: 135).

A trajetória da Universidade da Terceira Idade tem início na década de 70. Sua semente foi plantada inicialmente em paises da Europa. A primeira Universidade da Terceira Idade surgiu na cidade de Toulouse, França, em 1973. Segundo seu fundador, Pierre Vellas (apud Veras, 1997), elas deviam ser "fundamentalmente instituições de saúde pública, visando a elevar os niveis de saúde física, mental e social das pessoas de terceira idade, bem como colocar à sua disposição programas de atividades particularmente adaptados." (p.46) Na década de 1980, as Universidades da Terceira Idade francesas passam a atuar com um programa educacional mais amplo, 
baseado em três eixos: participação, autonomia e integração. (VERAS, 1997: 47).

Na Suiça, a Universidade da Terceira Idade de Neuchâtel cria três modelos de pesquisas, com a participação dos idosos em papéis diferentes As pesquisas são feitas para, com e pelos estudantes idosos. As pesquisas para os estudantes idosos são elaboradas por especialistas e têm como objetivo combater os efeitos do envelhecimento. As pesquisas com os estudantes idosos Ihes proporcionam condições de um engajamento maior, pois mobilizam seus conhecimentos, criatividade, vontade, inteligência e memória. As pesquisas feitas pelos estudantes idosos dão-lhes condições de exercer sua autonomia $e$ independência em relação aos seus formadores, uma vez que tenham adquirido o rigor cientifico, o espírito crítico e a solidez da reflexão (VERAS, 1997: 48).

Discorrendo sobre o valor das Universidades da Terceira Idade, enfatiza Veras (1997).

"De todo modo, não se pode negar a importância das Universidades da Terceira ldade na difusão de novos conhecimentos, na aquisição de outros aprendizados e na participação efetiva de certos grupos de idosos nas atividades universitánas: $E$ como as representações sociais da velhice sempre estiveram associadas ao isolamento e a inatividade, as UTI (Universidade da Terceira ldade) passam a constituir um dos temitónios ideais de construção da nova imagem da velhice. Combinando sociabilidade com educação permanente, elas 
simbolizam, para todas as gerações, a nova identidade da velhice, através da difusão de um outro modo de vida." (p. 49-50).

Modo de vida, este, proposto no documento da Declaração de Adelaide (Austrália, 1988), que diz:

“O principal propósito de uma politica pública saudável é criar um ambiente favorável, para que as pessoas possam viver saudáveis. Criar ambientes sociais e físicos comprometidos com a saúde."

No Brasil, essas universidades surgem quando as instituições européias já completavam sua terceira década de existência. Trazem, consigo, a possibilidade do rompimento com o preconceito que cerca o idoso. Isso porque ela pode conduzi-lo a experiências até então não vividas, como o acesso ao conhecimento não sistematizado, mas criativo, ao mundo da arte, da literatura, do lazer, e muitas outras atividades, que em um dado momento da vida aquele cidadão não pôde desenvolver, seja por questões pessoais, ou mesmo institucionais, permitindo, assim a expansão de seu universo de conhecimento e de atuação. (VERAS, 1997: 50).

A Universidade da Terceira Idade parece ter uma missão grandiosa junto àqueles idosos que a vêem como espaço de manutenção de saúde; ser o campo que possibilita à pessoa se abrir, se orientar para o aprender; dar-lhe tudo o que a educação tem como objetivo e finalidade, porém fazendo coincidir esses objetivos e finalidades com 0 anseio das pessoas nesse momento da vida, e não repetindo o modelo tradicional que pensa o homem 
e não permite que este pense, sinta, perceba, intua, enfim, integre a sua personalidade. (GOLDMAN, 1999: 140).

No entanto, a Universidade da Terceira Idade para alcançar sua missão há que caminhar no sentido de possibilitar a integração entre os alunos jovens (graduação) e idosos (os da Terceira Idade). Na Universidade São Francisco, Campus de Bragança Paulista, aquela relativa a da terceira idade funciona como um apêndice. $O$ idoso não interage com os demais alunos, não fazem as mesmas disciplinas, as salas de aulas e os horários são separados, as atividades são diferenciadas nâo havendo assim a troca de experiências e conhecimentos entre os "alunos". O idoso não pode dispor de serviços, como por exemplo, o Serviço de Orientação ao Estudante SOE, que é oferecido aos alunos da graduação e tem como objetivo principal acolher os alunos, ouvi-los, orientá-los, envolvê-los nas atividades que são oferecidas pela Universidade. Os alunos idosos não são atendidos neste espaço, embora a idéia embrionária do serviço seja de espaço para o aluno, estes idosos são considerados alunos diferenciados. Esta diferença é sentida pelo idoso que questiona sempre que pode.

Questionamos esta postura pois entendemos que a Universidade para a Terceira Idade é um espaço onde as trocas de experiências e de conhecimento possam acontecer.

Vale a pena ressaltar aqui, o preconceito em se encarar a velhice como doença, porque a saúde pode ser mantida mesmo na idade avançada, além 
do que, saúde perfeita não existe nem na infância. "A saúde é um estado de equilibrio geral psicofisiológico: o social, o cultural, o trabalho, a afetividade e a participação politica são ingredientes intervenientes à saúde". (CONFORT, 1979:9)

Concordamos com Confort (1979), quando explica que: "a percepção que o idoso tem de sua saúde e de seu envelhecimento é resultado da mesma matéria-prima, ou seja, dos significados e valores da cultura na qual o idoso está inserido." (p. 10).

Acredito que o importante é que se busque criar novas representações sociais sobre 0 binômio saúde $\times$ velhice, retirando-lhe as conotações depreciativas. 


\subsection{PROCEDIMENTOS DA PESQUISA}

Entendemos que a metodologia não é uma questão prévia à produção teórica nem ao menos uma mera decorrência desta, mas se refere ao próprio movimento teórico do pensamento, ou do sujeito que busca apreender e reconstituir o objeto sobre o qual se debruça a investigação. (MINAYO, 1996: 16).

Dessa forma, para identificarmos o significado que a cultura exerce sobre a maneira como o idoso olha para sua própria saúde, parece pertinente, caracterizar o objeto de estudo dessa pesquisa, retomando o histórico de como surgiu o projeto de uma Universidade para a Terceira Idade.

Como vimos anteriormente, dos movimentos que visam à valorização do idoso é que surgem as Universidades para a Terceira Idade, por entenderem serem essas uma espaço onde o idoso pode conservar certa atividade intelectual, criadora ou afetiva, sendo tudo isso indispensável ao bom funcionamento do organismo. (GOLDMAN, 1999: 135).

A Universidade São Francisco no decorrer de sua história, foi procurada, em agosto de 1994, por um grupo de idosos, interessados em participar de atividades especificas para essa faixa etária. Ciente do crescimento quantitativo e qualitativo de idosos no Brasil, representado pelo grande número de adultos inativos e aposentados, com idade acima de 45 anos e do envolvimento de outras Universidades, tais como a PUC de Campinas, PUC de São Paulo, a USP, que já tinham propostas de trabalho com essa 
população, resolveu através das mais diversas abordagens propor o projeto: "Universidade para a Terceira Idade", visando ao atendimento das aspirações desse grupo.

Este projeto tinha como finalidade a busca entre tantas outras coisas do concurso social harmonioso do idoso, quer consigo mesmo, quer com a sociedade, quer com a comunidade acadèmica da qual fariam parte, colaborando, assim, para que não se tornassem pessoas alheias ao processo social. (Projeto de Implantação da Universidade para a Terceira Idade, 1994: 2).

Deste projeto poderiam participar pessoas de ambos os sexos, com 40 anos ou mais e nivel de escolaridade adaptado às necessidades das disciplinas escolhidas por eles, residentes em Bragança ou nas cidades vizinhas.

As atividades propostas foram oferecidas através de disciplinas semestrais, que poderiam ser escolhidas de acordo com o interesse, possibilidade e nivel de instrução dos participantes.

A seleção era realizada através de entrevistas, momento em que as orientações quanto à escolha de disciplinas, seriam dadas. O valor da mensalidade, seria proporcional ao nümero de disciplinas escolhidas para serem cursadas no semestre, todas teriam o mesmo custo. 
As aulas seriam oferecidas semanalmente no periodo da tarde, sendo que em cada tarde poderiam ser ministradas 2 disciplinas com 2 horas-aula cada uma. Ressaltamos que à tarde não há aulas nos cursos de graduação. As salas ficam vazias.

A partir de sua implantação, este projeto sofreu algumas modificações para melhor adaptar-se à realidade e à demanda dos 170 idosos que buscam a Universidade para a Terceira Idade - USF. Anualmente avaliavam-se as disciplinas oferecidas, o interesse dos idosos/alunos e suas sugestões eram levadas em conta.

Nosso interesse de estudo pautou-se sobre a questão: O olhar do idoso para sua própria saúde - explorado a partir da experiência com o grupo de alunos/idosos que freqüentavam a Universidade para a Terceira Idade no ano de 1999, quando eu era professora do grupo. Os alunos me tratavam como parece que só eles mesmos tratam as pessoas que representam o saber, ou que detêm conhecimento: com respeito! Reproduziam a cultura de uma sociedade onde o mestre, embora, com menos idade, deve ser ouvido com atenção e que com certeza se tornará um amigo. Essas são "estruturas de significados socialmente estabelecidas, nos termos dos quais as pessoas fazem certas coisas como sinais de conspiração e a elas se aliam". (GEERTZ, 1973: 23). Nas nossas atividades não havia uma abordagem especifica ao atendimento clinico de saúde 
Para viabilizar a proposta de entender a influência cultural e chegar ao objetivo projetado - o significado, para o idoso, de sua própria saúde entendemos que a abordagem qualitativa seria o caminho para desenvolvermos a investigação, respaldamo-nos em dados de fontes fidedignas apresentando através de duas tabelas (expostas a seguir) as características deste grupo. Optamos pela abordagem qualitativa por entendermos ser mais capaz de "incorporar a questão do significado e da intencionalidade como inerentes aos atos, às relações e às estruturas sociais, sendo estas últimas tomadas tanto no seu advento quanto na sua transformação, como construções humanas significativas". (MINAYO, 1996:70).

Concordamos com Minayo (1996) quando destaca que a realidade apresentada pelos dados qualitativos e quantitativos interagem de forma dinâmica, não permitindo, assim, qualquer dicotonia. O importante é a criatividade do pesquisador. (p. 16).

A fala, o discurso é o principal instrumento de captura de dados: queremos, sobretudo, ouvir os alunos/idosos, pressupondo que: "palavras são linhas sonoras que expressam o sentido e a ideologia mas, simultaneamente, transpiram emoção, afetos e desafetos, ou seja, desvela a existência social através de suas particularidades como seres histónicos". (FRANCO, 1994:155). 
Seres históricos aqui entendidos "como produtos de circunstâncias determinadas e, ao mesmo tempo, produtores dessa mesma história que se concretiza na prática social, via pensamento-linguagem e ação, que se deixa impulsionar por necessidades biopsicológicas, que se orienta a um fim e que se expressa no conjunto, socialmente elaborado, das representações sociais". (id. ibid. p. 157).

Para se expressar, "o ser humano recorre a símbolos, porque, por meio deles, que ora desvelam, ora ocultam, a linguagem pode nomear os seres e levar à percepção da ressonância da palavra originária". (MOURA, 1996: 48).

"O discurso é sempre uma revelação do sentido do SER e do existir do homem, que, enquanto ser, encontra-se no mundo, mas com os outros, partilhando com eles um ser em comum, que vai tornar a sua linguagem possivel, através da comunicação $e$ expressão". (MOURA, 1996: 49).

Voltando à Geertz:

"Nossas impressões sobre a vida humana săo colhidas uma a uma e permanecem, para a maioria de nós, frouxas e desorganizadas. Até encontrarmos na literatura coisas que subitamente as coordenam. A cultura de um povo é um conjunto de textos. As sociedades, como as vidas, contém suas próprias interpretações. É preciso apenas descobnir o acesso a elas". (GEERTZ, 1973:40).

Esta linha de investigação, dirigida para uma certa prática de pesquisa, envolve: seleção prévia dos informantes, detalhada coleta de dados, a partir de entrevistas semi-estruturadas apoiadas em um roteiro de questõ $\epsilon_{3}$ que 
nos levam ao contexto do significado que dizem respeito à saúde. Como só adquire significado aquilo que é percebido e interpretado, perguntamo-nos a todo instante o que a ocorrência de determinada fala está transmitindo. Essa análise nos leva às idéias de Geertz sobre a importância da cultura.

Afirma então esse autor:

"A cultura está localizada na mente e no coração dos homens. Devemos atentar para o compontamento dos homens, pois é através do fluxo do comportamento -ou, mais precisamente, da ação social - que as formas culturais encontram articulação. Elas encontram-na também, em várias espécies de artefatos e vários estados de consciência. Todavia, nestes casos o significado emerge do papel que desempenham, no padrão de vida decorrente, não de quaisquer relações intrínsecas que mantenham umas com as outras." (GEERTZ, 1973: 27 ).

Nessa perspectiva, ponderamos nos servir do estudo das representações sociais dos idosos, por entendermos que a temática das representações implica adentrar uma concepção produzida no entrecruzamento de diferentes ciências sociais e na tensão resultante da intersecção do individual com o social... [as representações] contêm um "modelo" de homem e de sociedade; explicam o real e respondem à necessidade de criação de uma identidade social na qual a questão da diferenciação social aparece, muitas vezes, como elemento organizador e justificador de comportamentos... (YASBEK, 1993: 78).

Discorrendo, ainda sobre as representações sociais Yasbek (1993) nos explica que: 
"O real, no entanto, é constituido de relações atravessadas pelo confito e permeadas por antagonismos e, desse modo, se de um lado, as representações reproduzem a lógica e o discurso dominante, de outro, reproduzem contraditoniamente o seu contránio, a sua transgressão que se expressa como resistência, criatividade e superação de um determinismo reducionista, apontando rupturas e libertação." (p. 78-79).

Nessa perspectiva, as representaçōes sociais devem ser analisadas criticamente, pois correspondem às situações reais da vida, uma vez que a visão de mundo dos diversos grupos expressa as contradições e conflitos presentes nas condiçōes em que foram engendrados. Elas não são necessariamente conscientes, são a mistura das idéias das grandes massas, da elite, assim como da filosofia corrente.

A importância do estudo das representaçōes sociais, das interpretaçōes dos significados também é citada por Minayo que explica:

"as Representações Sociais se manifestam em palavras, sentimentos e condutas e se institucionalizam, portanto, podem e devem ser analisadas a partir da compreensão das estruturas e dos comportamentos sociais, mediada pela linguagem, tomada como forma de conhecimento e de interação social". (MINAYO, 1996: 67).

As contribuições de Bourdieu (1998) nos subsidiam na modelagem dos pressupostos deste estudo quanto à abordagem do sujeito. Trata-se das implicações da relação pesquisador/sujeito, no acolhimento das falas, na atitude de escuta e na elaboração de uma comunicação "sem violência simbólica", visto que é o território do idoso que deve aflorar neste espaço. À 
medida que, por um lado, nos defrontamos com o idoso, ele se abre, não mente, confia, se sente valorizado e por se sentir valorizado "fala"; por outro lado, trata-se também da relação pesquisador/universo de investigação, estabelecendo os nexos entre a realidade e as categorias que emergem das representações sem a preocupação de enformá-las nesta ou naquela vertente ideológica, mas demonstrando o caráter plural e contraditório que envolve a apreensão do real.

É, igualmente relevante, o texto de Spink (1992) que nos esclarece sobre - detalhamento técnico para captura dos elementos significantes das representações, demonstrando a possibilidade de obtê-los seja através de um único sujeito, seja com um procedimento amostral ampliado.

Para a realização deste estudo: entender como o idoso vê a sua própria saúde através da influência cultural, foram selecionados os idosos que estavam matriculados na Universidade para a Terceira Idade, através das fichas de matricula e compunham um universo de 170 alunos. Dentro deste universo, foram identificados os que estavam na faixa etária de 60 anos e mais, totalizando 59 idosos assim caracterizados: oito do sexo masculino e cinqüenta e um do sexo feminino.

Podemos observar que embora o número seja menor, há homens, nesta faixa etária, que procuram e participam da Universidade para a Terceira Idade. 
Não se sabe ainda, mas existem algumas hipóteses que tentam explicar a pouca presença dos homens nestas atividades. Há que se levar em conta que a aposentadoria, muitas vezes, não permite que os homens se afastem totalmente da vida laborativa e eles retornam ao mercado de trabalho em busca de complementação salarial.

Uma outra hipótese diz respeito às características marcadamente femininas dessas atividades, tais como a freqüência à Universidade para Terceira idade, aos centros de convivências aos trabalhos voluntários. "Observa-se também uma feminilização do envelhecimento no Brasil. O número de mulheres idosas, se comparado ao de homens de mais de 60 anos de idade, já constitui um contingente expressivamente maior há muito. No Brasil, desde 1950, as mulheres têm maior esperança de vida, ao nascer, e esta diferença está ao redor de sete anos e meio." (GORDILHO, 2000:14)

Dentre os 59 idosos nem todos residiam em Bragança Paulista o que nos chamou atenção. Considerando que as cidades são próximas a Bragança, mas os idosos têm que se deslocar de carro, dirigindo ou de "carona", enfrentar uma estrada, Fernão Dias, que estando em processo de alargamento se torna muito perigosa, dado o fluxo e a movimentação de ônibus, caminhão, carretas o tempo todo, pois é via de ligação com Minas Gerais

Demonstro na seguinte tabela as cidades de onde os idosos/alunos vêm. 
TABELA 1 - Distribuição dos idosos que freqüentavam a Universidade da Terceira Idade - Universidade São Francisco, por cidade onde residiam - 1999.

\begin{tabular}{lc}
\hline \multicolumn{1}{c}{ Cidade onde reside } & $\mathbf{N}^{\mathbf{0}}$ \\
\hline Bragança Paulista & 47 \\
Atibaia & 9 \\
Piracaia & 2 \\
Pinhalzinho & 1 \\
\hline Total & 59 \\
\hline
\end{tabular}

Fonte: Ficha de Matricula

Após expormos para os idosos/alunos o tema que estávamos estudando, "saúde do idoso" e nosso interesse em resgatarmos suas particularidades através de entrevistas que seriam gravadas espontaneamente e com consentimento dos mesmos, 13 idosos se dispuseram a conversar conosco. Os mesmos tinham disponibilidade $e$ interesse em contribuir com seus depoimentos e estavam na faixa etária de 60 anos e mais como demonstra o quadro a seguir.

Diziam eles: "Eu quero participar de tudo, me sinto lisonjeado em dar meu depoimento e fazer parte de uma pesquisa."

TABELA 2- Distribuição dos idosos que freqüentavam a Universidade da Terceira Idade - Universidade São Francisco, segundo a faixa etária -1999.

\begin{tabular}{|c|c|}
\hline Idade & Número \\
\hline $60+63$ & 08 \\
\hline $64 \longmapsto 67$ & 03 \\
\hline $68-70$ & 02 \\
\hline Total & 13 \\
\hline
\end{tabular}

Fonte: Entrevistas realizadas 
Os 13 idosos que participaram da pesquisa se caracterizam assim: 3 do sexo masculino e 10 do sexo feminino. Dez residiam em Bragança e 3 em Atibaia. Encontramos dentre os 13 , graduados em: Engenharia, Direito e Letras; 5 professoras de escolas primárias; 3 do lar; 1 Corretor de Imóveis e uma podóloga. Desses, 3 recebem pensão, 1 continua na ativa e 9 estão aposentados por tempo de serviço.

O instrumento utilizado para a coleta de dados foi a entrevista semiestruturada composta por um roteiro de questões, essas previamente testadas. O roteiro foi construido a partir de quatro eixos centrais, na tentativa de buscar o significado que o idoso dá para sua própria saúde. Os eixos são:

- Como se vê com a idade que tem;

- O que significa ter saúde;

- Como vê a sua própria saúde;

- A importância da Universidade para a Terceira Idade, com relação à própria saúde.

Essa forma de coleta, segundo Jahoda, citada por Minayo (1996), é a fonte que fornece dados referentes a fatos, idéias, crenças, maneiras de pensar: opiniões, sentimentos, maneira de sentir, de atuar; conduta de comportamento presente ou futura; razões conscientes ou inconscientes de determinadas crenças. 
A modalidade de entrevista semi-estruturada "ao mesmo tempo que valoriza a presença do investigador, oferece todas as perspectivas possiveis para que o informante alcance a liberdade e a espontaneidade necessárias, enriquecendo a investigação." (TRIVINOS in SIMIONI, 1997: 7).

O discurso dos diferentes depoentes foi gravado em fitas e transcrito literalmente de forma a recuperar a sua integralidade, com o termo de consentimento previamente assinado. Entende-se por "transcrição", a reprodução num segundo exemplar de um documento, em plena e total conformidade com sua primeira forma, em total identidade, sem nada que o modifique. (QUEIROZ, 1991: 86).

No momento da entrevista, os depoentes foram ouvidos sem que se perdesse de vista o caráter histórico e cultural, ou seja, o contexto das suas falas. Em outras palavras, procurou-se analisar o significado que o idoso dá para sua própria saúde, levando-se em conta os acontecimentos e as situações vividas pelos entrevistados - no caso, a experiência do envelhecimento, as alterações na sua própria saüde, o envolvimento com a vida acadêmica. Levando-se em consideração o que nos diz Geertz: "No estudo da cultura, os significantes não são sintomas ou conjuntos de sintomas, mas atos simbólicos ou conjuntos de atos simbólicos e o objetivo é a análise do discurso social". (GEERTZ, 1973: 36).

Além da entrevista gravada, construímos um diário de campo composto pelas observações que fazíamos quanto a postura de cada um deles, suas 
emoções e comportamento durante a entrevista. Escreviamos o que percebiamos para que posteriormente essas observações fossem anexadas às transcrições das falas.

O diário de campo, documento extremamente rico e importante sobre as ações e sensações demonstradas mas não faladas, nos remete a lembrança de como eles efetivamente se mostram. Muitas vezes as falas não condizem com o que se aparenta. Novamente essa lembrança nos remete a Geertz que nos diz: "O comportamento humano é visto como ação simbólica. O que chamamos de nossos dados são realmente nossa própria construção das construções de outras pessoas, do que elas e seus compatriotas se propõem". (GEERTZ, 1973: 19).

O que devemos indagar é qual a importância de determinado significado. Para os idosos que foram ouvidos, ter saúde não significa estar livre de sentir "dores", ou até mesmo "adoecer". Para eles essas coisas fazem parte de um processo natural da vida. O importante para eles é ter a possibilidade de ainda fazer parte deste processo, ou seja, da vida.

Os idosos entrevistados se mostraram com seu caminhar lento, mas com muita alegria. Com dores que já os acompanhavam desde jovem e que por essa razão já aprenderam a conviver com as mesmas. Desconfiados, emocionados, brincalhões. Enfim, os sujeitos se desvelam como são e como estão a partir da relação de amizade e proximidade estabelecida entre o 
pesquisador e o pesquisado e por se sentirem importantes em participar de uma pesquisa e valorizados por serem ouvidos.

As falas foram analisadas de maneira que o resultado pudesse apontar a real descrição das representações dos depoentes sobre o significado de sua própria saúde. Entende-se por análise "o recorte de uma totalidade nas partes que a formam, que são então apreendidas na seqüência apresentada em sua naturalidade para, num segundo momento, serem restabelecidas numa nova coordenação." (QUEIROZ, 1991: 92).

Seguimos os passos seguintes para chegarmos à análise temática:

- leitura detalhada das respostas às questões 1 a 4, depois de serem transcritas;

- identificação das idéias centrais e expressões-chave contidas nas entrevistas;

- recorte das expressões e reunião das mesmas no discurso;

- organização dos quadros de significados;

- agrupamento das expressões por semelhança;

- análise temática.

Embora tenhamos elencado esses passos para serem seguidos, tentamos nos aproximar dos significados que as falas nos trazem num contexto pois "como já foi observado, o que inscrevemos (ou tentamos fazê-lo) não é o discurso social bruto ao qual não somos atores, não temos 
acesso direto a não ser marginalmente, mas apenas àquela pequena parte dele que os nossos informantes nos podem levar a compreender." (GEERTZ, 1973: 30). 
CAPÍTULO II 


\section{CAPÍTULO}

\section{ANÁLISE TEMÁTICA}

Após ouvirmos através das gravações e lermos as transcrições várias vezes as entrevistas feitas, com o cuidado de não perdermos de vista a contextualização de cada fala, chegamos a um discurso ou um pensamento encadeado discursivamente sobre as indagações levantadas no roteiro e feitas a cada entrevistado. O que interessa assinalar nesta análise são as Idéias Centrais e as Expressões que resgatam a essência do conteúdo discursivo e que consistem nas Representações Sociais sobre o tema proposto.

Como nos explica Lefévre (2000): "Conceber as Representações Sociais consiste em entendê-las como a expressão do que pensa ou acha determinada população sobre determinado tema. Este pensar, por sua vez, pode se manifestar, dentre outros modos, através do conjunto de discursos verbais emitidos por pessoas dessa população". (p.13).

Ainda, segundo Lefévre (2000): "As idéias centrais se referem às afirmações que permitem traduzir o essencial do conteúdo discursivo explicitado pelos sujeitos em seus depoimentos". (p.18).

As expressões-chave são constituidas por transcrições literais de partes dos depoimentos, que permitem o resgate do essencial do conteúdo discursivo dos segmentos em que se divide o depoimento. (id. ibid. f. 18). 
Para cada idéia central e expressões-chave correspondentes correlacionamos o número do sujeito a que se refere: S1, S2 ... Sn. Portanto os Discursos dos Sujeitos Coletivos correspondentes a cada idéia central também foram correlacionados com os mesmos sujeitos.

Abaixo apresentamos um quadro onde Questão Levantada, Idéia Central, Expressões-chave, presentes nos discursos dos entrevistados nos possibilitam uma análise das representações sociais. 


\subsection{Idéias Centrais e Expressões-Chave.}

Os textos das expressões-chave e dos $\mathrm{DSCs}^{3}$, uma vez que são transcrições da "fala" dos informantes, estão redigidos numa linguagem muito próxima da forma oral de se expressar.

\begin{tabular}{|c|c|c|}
\hline Questão Levantada & Idéia Central & Expressões-Chave \\
\hline $\begin{array}{l}\text { 1. Como se vê } \\
\text { com a idade } \\
\text { que têm? }\end{array}$ & $\begin{array}{l}\text { Não se sentem } \\
\text { com a idade que } \\
\text { estão. }\end{array}$ & $\begin{array}{l}\text { - A idade não me afeta em } \\
\text { nada, nunca me afetou. Não } \\
\text { me incomoda ter } 60 \text { anos, } \\
\text { nem penso nisso. (S, 2) } \\
\text { - Não consigo acreditar na } \\
\text { idade que eu tenho. A cultura } \\
\text { que a gente tem em relação } \\
\text { ao idoso é muito falha, eu não } \\
\text { estou me sentindo um } \\
\text { incapaz, um traste. (S, 4) } \\
\text { - Me vejo muito bem. Eu nunca } \\
\text { me preocupei com a minha } \\
\text { idade. (S,12) } \\
\text { - Me sinto muito bem. Sou } \\
\text { muito feliz. Faço o que nem } \\
\text { moça faz. Tenho disposição, } \\
\text { tenho coragem. (S,6) } \\
\text { - A mesma coisa que eu me via } \\
\text { com } 20,30,40 \text { anos. (S,11) }\end{array}$ \\
\hline
\end{tabular}

\footnotetext{
${ }^{3}$ DSCs - Discursos dos Sujeitos Coletivos
} 


\begin{tabular}{|c|c|c|}
\hline Questão Levantada & Idéia Central & Expressões-Chave \\
\hline & \multirow{4}{*}{$\begin{array}{l}\text { Percebem a } \\
\text { diminuição da } \\
\text { força ocorrida em } \\
\text { seus corpos. }\end{array}$} & $\begin{array}{l}\text { Com um pouquinho menos } \\
\text { de força, mas fora isso, } \\
\text { totalmente bem. }(\mathbf{S}, 11)\end{array}$ \\
\hline & & $\begin{array}{l}\text { Me vejo um pouco mais } \\
\text { cansado me vejo bem. } \\
\text { Organizei minha vida: faço } \\
\text { ginástica, nado, estudo na } \\
\text { Universidade da Terceira } \\
\text { Idade, tenho rotina excelente. } \\
\text { Estou sempre em contato. } \\
(\mathbf{S}, 1)\end{array}$ \\
\hline & & $\begin{array}{l}\text { Estou feliz. Bem comigo } \\
\text { mesmo. Apesar de vários } \\
\text { problemas que eu estou } \\
\text { tendo que enfrentar, mas } \\
\text { estou dando conta. }(\mathbf{S}, \mathbf{3})\end{array}$ \\
\hline & & $\begin{array}{l}\text { Eu achava que quando } \\
\text { chegasse aos } 60 \text { anos, eu } \\
\text { seria muito idoso, agora vejo } \\
\text { que não. Eu cheguei aos } 60 \\
\text { e ainda tenho bastante pela } \\
\text { frente, né? Me sinto bem, } \\
\text { graças a Deus, me sinto } \\
\text { bem. }(\mathbf{S}, 10)\end{array}$ \\
\hline & $\begin{array}{l}\text { Sentem-se mais } \\
\text { maduros e sábios. }\end{array}$ & $\begin{array}{l}\text { - Me vejo muito bem. Nunca } \\
\text { penso na minha idade. Eu } \\
\text { acho que a gente deve } \\
\text { envelhecer, mas não ir } \\
\text { perdendo as forças. É uma } \\
\text { lapidação prá gente. (S,12) } \\
\text { - Me sinto mais madura, muito } \\
\text { mais sábia... Aquela ânsia que } \\
\text { movia a gente pra viver, ela } \\
\text { está tranqüila, eu sei que o dia } \\
\text { de amanhã virá e se não vier } \\
\text { é porque não tem que vir. } \\
\text { Quando vocé se aposenta é } \\
\text { uma sensação terrivel de ser } \\
\text { excluida, não só do seu } \\
\text { ambiente de trabalho, até da } \\
\text { própria vida. Eu achei terrivel } \\
\text { aposentar, até deprimi. (S, i3) }\end{array}$ \\
\hline
\end{tabular}




\begin{tabular}{|c|c|c|}
\hline Questão Levantada & Idéia Central & Expressões-Chave \\
\hline & $\begin{array}{l}\text { O corpo não } \\
\text { ajuda mas a } \\
\text { cabeça é boa. }\end{array}$ & $\begin{array}{l}\text { - Eu me vejo "moleca" } \\
\text { (cabeça), mas o corpo não } \\
\text { ajuda, mas eu acho que o } \\
\text { que me ajuda é essa cabeça. } \\
\text { A cabeça é boa, o organismo } \\
\text { (corpo) nunca prestou } \\
\text { mesmo, o corpo nunca foi } \\
\text { bom. (S,7) }\end{array}$ \\
\hline & & $\begin{array}{l}\text { - Estou limitado, não tenho } \\
\text { aquela força física de um } \\
\text { jovem, se eu não tivesse a } \\
\text { doença de Chagas, foi } \\
\text { detectado pela } 1^{\text {a }} \text { vez em } \\
1962 \text { embora eu me ache um } \\
\text { homem ainda até certo ponto } \\
\text { normal. }(\mathbf{S}, \mathbf{9})\end{array}$ \\
\hline & A conformaçåo. & $\begin{array}{l}\text { - Limitado, não tenho mais } \\
\text { aquela força física. Eu me } \\
\text { aceito assim mesmo. Eu não } \\
\text { reclamo, porque olha, diz } \\
\text { assim, quem já passou dos } \\
60 \text { tudo sobra, é tudo } \\
\text { chance, mais um dia. (S,9) }\end{array}$ \\
\hline & O despertar & $\begin{array}{l}\text { - Fico às vezes assustada de } \\
\text { ter } 60 \text { anos porque pra mim } \\
\text { o tempo não passou. Sinto } \\
\text { que não fiquei parada no } \\
\text { tempo. Eu acompanhei bem. } \\
\text { Quando os dois filhos } \\
\text { casaram eu me vi cara a } \\
\text { cara com meu problema, } \\
\text { comecei a ficar mal. Não } \\
\text { queria mudar para Bragança. } \\
\text { Então, fiquei muito triste, eu } \\
\text { tinha vontade de chorar, } \\
\text { depois foi passando. Agora } \\
\text { eu estou vendo que existem } \\
\text { outras coisas para serem } \\
\text { feitas, então já estou } \\
\text { esquecendo os problemas. } \\
\text { (S,8) }\end{array}$ \\
\hline
\end{tabular}




\begin{tabular}{|c|c|c|}
\hline Questão Levantada & Idéia Central & Expressões-Chave \\
\hline \multirow[t]{3}{*}{$\begin{array}{l}\text { 2. O que é ter } \\
\text { saúde. }\end{array}$} & Ter disposição. & $\begin{array}{l}\text { - Ter saúde é eu acordar de } \\
\text { manhä com aquela } \\
\text { disposição para comer, } \\
\text { andar, fazer ginástica. (S,1) } \\
\text { - É se sentir bem. É ter } \\
\text { disposição. (S,2) } \\
\text { - É ter disposição para } \\
\text { trabalhar, para passear, para } \\
\text { viajar, dançar. Eu danço, vou } \\
\text { em festas, vou em jantares, } \\
\text { viagens. É ter disposição } \\
\text { para tudo, né? (S,6) } \\
\text { - É eu ter disposição para fazer } \\
\text { tudo que eu quero fazer. } \\
\text { (S,10) } \\
\text { - Sem a saúde você não faz } \\
\text { nada. (S,9) }\end{array}$ \\
\hline & Não sentir dores. & $\begin{array}{l}\text { - É não ter dores. }(\mathbf{S}, \mathbf{7}) \\
\text { - Não ter problema de dor de } \\
\text { estômago, de cabeça, } \\
\text { financeiro, reumatismo. }(\mathbf{S}, \mathbf{5})\end{array}$ \\
\hline & $\begin{array}{l}\text { Estar com a } \\
\text { mente boa. }\end{array}$ & $\begin{array}{l}\text { - Acho que muito na cabeça, } \\
\text { né, mental. }(\mathbf{S}, \mathbf{1}) \\
\text { - A principal é a mental. Eu } \\
\text { valorizo demais a saúde } \\
\text { mental, porque eu percebi ao } \\
\text { longo da minha vida que um } \\
\text { problema fisico, um câncer, } \\
\text { ele atinge o portador, é ele } \\
\text { que vai sentir as dores, e um } \\
\text { problema mental atinge todos } \\
\text { da familia, né? }(\mathbf{S}, \mathbf{8})\end{array}$ \\
\hline
\end{tabular}




\begin{tabular}{|c|c|c|}
\hline Questão Levantada & Idéia Central & Expressōes-Chave \\
\hline & $\begin{array}{l}\text { É continuar } \\
\text { integrado à } \\
\text { sociedade. }\end{array}$ & $\begin{array}{l}\text { - É poder viver uma vida em } \\
\text { sociedade. }(\mathbf{S}, \mathbf{1 2}) \\
\text { - Estar de bem com todo } \\
\text { mundo, com a vida. }(\mathbf{S}, \mathbf{1}) \\
\text { - É eu viver e sentir bem no } \\
\text { meio que estou. }(\mathbf{S}, \mathbf{9}) \\
\text { - É participar da vida, sem } \\
\text { obstáculos. }(\mathbf{S}, \mathbf{4})\end{array}$ \\
\hline & $\begin{array}{l}\text { É continuar a } \\
\text { viver sem } \\
\text { restriçőes. }\end{array}$ & $\begin{array}{l}\text { - Não precisar ficar me } \\
\text { restringindo de muitas coisas. } \\
\text { (S,12) } \\
\text { - Levar uma vida saudável, } \\
\text { poder sair, comer. }(\mathbf{S}, \mathbf{1 2 )} \\
\text { - Fazer as coisas que gostaria } \\
\text { de fazer ou que já fez } \\
\text { anteriormente. (S,4) }\end{array}$ \\
\hline
\end{tabular}




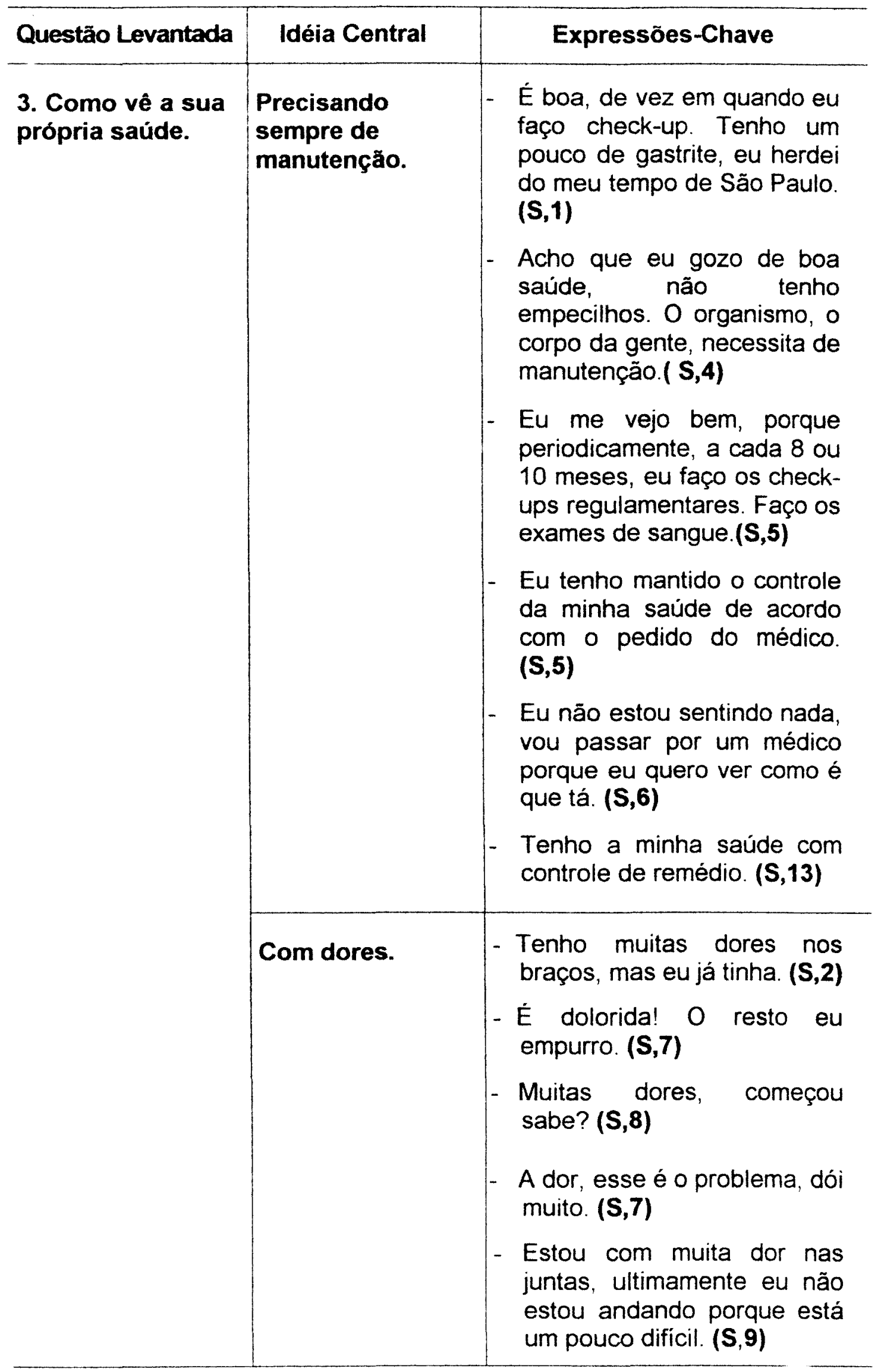




\begin{tabular}{|c|c|c|}
\hline Questão Levantada & Idéia Central & Expressões-Chave \\
\hline & \multirow[t]{4}{*}{$\begin{array}{l}\text { Com problemas } \\
\text { que aparecem } \\
\text { com a idade. }\end{array}$} & $\begin{array}{l}\text { - Eu mesma estou bem... } \\
\text { Apesar de uns probleminhas } \\
\text { que todos nós temos porque } \\
\text { eu não sou mais uma } \\
\text { garotinha, tenho problema } \\
\text { por exemplo, de triglicérides, } \\
\text { mas eu estou fazendo } \\
\text { regime, estou caminhando } \\
\text { bastante, já abaixou } \\
\text { bastante. }(\mathbf{S , 3 )}\end{array}$ \\
\hline & & $\begin{array}{l}\text { Tive um problema no } \\
\text { calcanhar, fiz fisioterapia, } \\
\text { não curou, essas coisas que } \\
\text { vão dizer são características } \\
\text { da idade, quando a gente é } \\
\text { mais jovem não tem tanto } \\
\text { desses problemas } \\
\text { musculares. }(\mathbf{S , 4 )}\end{array}$ \\
\hline & & $\begin{array}{l}\text { Atualmente eu tenho } \\
\text { problemas que eu não tinha } \\
\text { quando era mais nova, né? } \\
(\mathbf{S}, 12)\end{array}$ \\
\hline & & $\begin{array}{l}\text { - Estou com hérnia de disco, } \\
\text { tenho hérnia de hiato, são } \\
\text { enfermidades que vêm com } \\
\text { a idade. }(\mathbf{S , 1 2 )}\end{array}$ \\
\hline
\end{tabular}




\begin{tabular}{|c|c|c|}
\hline Questäo Levantada & Idéia Central & Expressões-Chave \\
\hline & $\begin{array}{l}\text { Emocionalmente } \\
\text { ruim }\end{array}$ & $\begin{array}{l}\text { - Com o casamento do meu } \\
\text { filho e a mudança de Säo } \\
\text { Paulo para Bragança, eu } \\
\text { deprimi, eu tinha muita } \\
\text { vontade de chorar, senti } \\
\text { dores e cansaço. (S,8) } \\
\text { - Estou precisando dar uma } \\
\text { viradinha, já fiquei muito } \\
\text { melhor do meu estado } \\
\text { psíquico. (S,8) } \\
\text { Tenho a impressão que não } \\
\text { é que a gente sai de dentro } \\
\text { de si própria, você permite } \\
\text { que a doença se vá. } \\
\text { Emocionalmente } \\
\text { bem. (S,13) } \\
\text { Eu vejo que as pessoas se } \\
\text { entregam, elas não reagem } \\
\text { e estão cada vez mais } \\
\text { doente. (S,11) }\end{array}$ \\
\hline & $\begin{array}{l}\text { Conformados } \\
\text { com a saúde } \\
\text { que têm. }\end{array}$ & $\begin{array}{l}\text { - Limitada, com bastante } \\
\text { deficiência, mas já que eu } \\
\text { não estou hoje com } 30 \text { ou } \\
40 \text { anos, vou fazer } 70 \text {, acho } \\
\text { que está bom. }(\mathbf{S}, 9) \\
\text { - Na minha idade, estou } \\
\text { achando que eu estou bem } \\
\text { mesmo de saúde. (S,10) } \\
\text { - Eu me conformo com a } \\
\text { minha saúde, não adianta } \\
\text { me revoltar, né? (S,9) }\end{array}$ \\
\hline
\end{tabular}




\begin{tabular}{|c|c|c|}
\hline Questão Levantada & Idéia Central & Expressões-Chave \\
\hline $\begin{array}{l}\text { 4. A Importância } \\
\text { da Universidade } \\
\text { com relação à } \\
\text { própria saúde. }\end{array}$ & $\begin{array}{l}\text { Conviver com } \\
\text { outras pessoas }\end{array}$ & 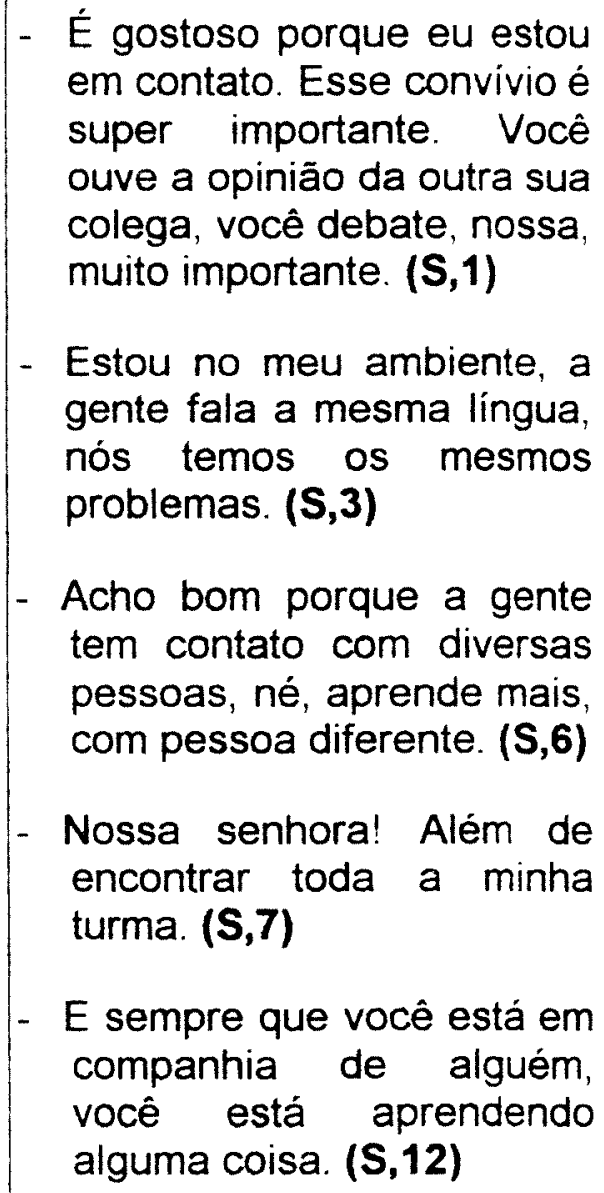 \\
\hline & $\begin{array}{l}\text { Fazer novas } \\
\text { amizades }\end{array}$ & $\begin{array}{l}\text { - A quantidade de pessoas da } \\
\text { cidade e mesmo de } \\
\text { Atibaia, tem muita gente } \\
\text { que nós não conheciamos, } \\
\text { então nós tivemos } \\
\text { relacionamento muito } \\
\text { grande, de amizade. (S,5) } \\
\text { - Fiz muitas amizades aqui } \\
\text { em Bragança eu não } \\
\text { conhecia quase ninguém, } \\
\text { eu vinha de São Paulo. foi } \\
\text { muito gratificante, eu acho } \\
\text { que Bragança inteira devia } \\
\text { se dedicar a isso, pra esses } \\
\text { encontros. (S,11) }\end{array}$ \\
\hline
\end{tabular}




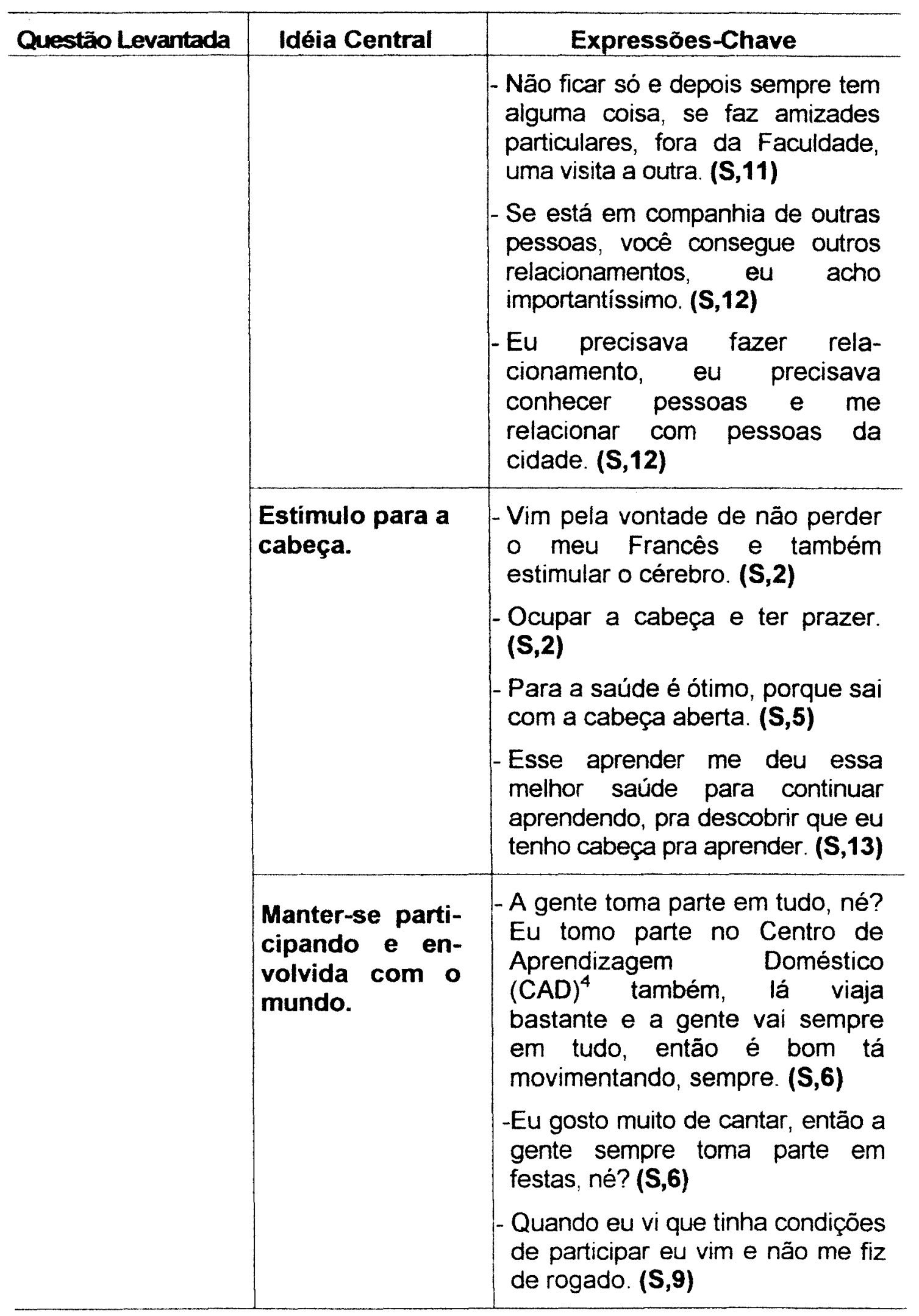

\footnotetext{
${ }^{4}$ O CAD - Centro de Aprendizagem Doméstico é um programa do SESI, Servico Educacional Social da Indústria, desenvolvido em Bragança para os idosos.
} 


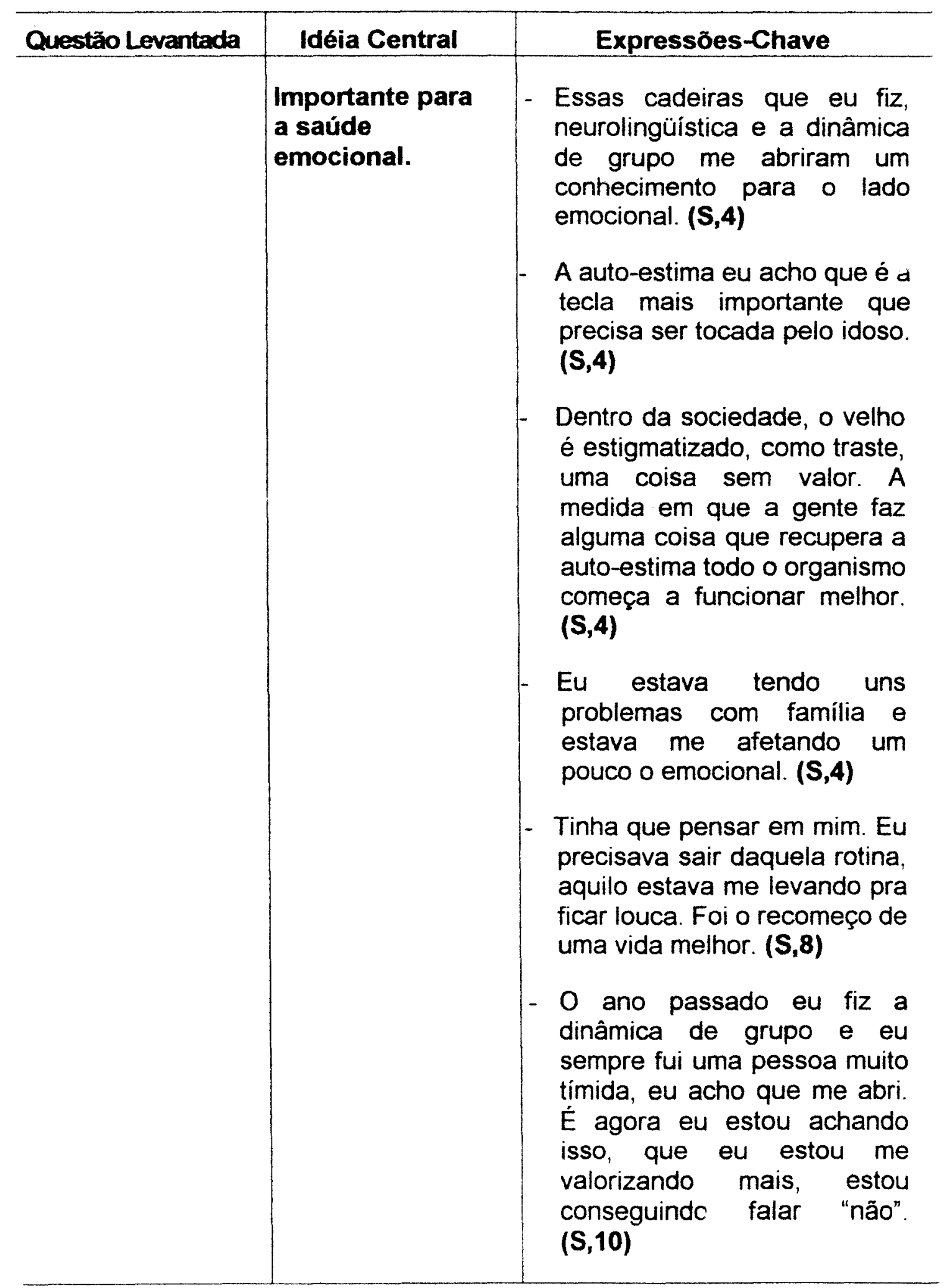




\begin{tabular}{l|l|l}
\hline Questão Levantada & \multicolumn{1}{|c|}{ Idéia Central } & Expressões-Chave \\
\hline & Romper os & O homem não gosta de \\
& estigmas & vir aqui, não sei porque, \\
& não sei se é machismo, \\
& eu como não tenho \\
& preconceito, não tou nem \\
& aí com nada, pra mim foi \\
& muito bom. (S,4) \\
\hline
\end{tabular}

\subsection{Sujeitos e seus discursos.}

Após a apresentação dos quadros, onde esquematizamos as falas mais consistentes dos idosos no que diz respeito às questões levantadas, agrupamos as que são mais capazes de "incorporar a questão do significado e da intencionalidade como inerentes aos atos, às relações e às estruturas sociais, sendo estas últimas tomadas tanto no seu advento quanto na sua transformação, como construções humanas significativas". (MINAYO, 1996:70).

Buscamos com isso resgatar o discurso como signo de conhecimento dos próprios discursos. Formando, assim o Discurso do Sujeito Coletivo (DSC).

Segundo nos explica Lefèvre (2000):

"Com os DSCs, os discursos não se anulam ou se reduzem a uma categoria comum unificadora, o que se busca fazer é reconstruir, com pedaços de discursos individuais, como em um quebra-cabeças, tantos discursos-sintese quantos se julgue necessário para expressar uma dada "figura", ou seja, um dado pensar ou representação social sobre um fenômeno". (p.19). 
O que se pretende é tornar mais clara a representação social de um dado imaginário. Visualiza-se melhor a representação social, na medida em que ela aparece não sob uma forma (artificial) de quadros e tabelas de categorias, mas sob uma forma (mais viva e direta) de um discurso, que é o modo como os individuos reais, concretos, pensam. (SIMIONI, 1997:11).

Com os DSCs, as falas que reúnem pedaços de diferentes discursos individuais deram forma a um único discurso, ou seja, a maneira de pensar das pessoas sobre o tema abordado neste trabalho e este pensar demonstrou a representação social dos mesmos.

Esse pensar, como esclarece Lefèvre (2000): "Não é apenas o equivalente ao conteúdo que eventualmente verbalizam nas entrevistas, mas além e mais do que isso é aquilo que podem pensar, ou seja, o que está no horizonte de pensamento de uma cultura. Isto significa, por exemplo, que o pensamento de um dado indivíduo pode incluir também aquilo que outros individuos socialmente equivalentes verbalizam por ele". (p.35).

Em sintese, o DSC é como se o discurso de todos fosse o discurso de um. (SIMIONI, 1997: 13).

Relembro que neste trabalho foi utilizada a entrevista gravada, onde o entrevistado pode se colocar à vontade e expressar o significado que eles dão à sua própria saúde, além de expressarem seu contentamento, de se sentirem importante, não só pelo fato de estarem falando, refletindo e olhando para si próprios mas, principalmente, por estarem sendo ouvidos. 


\section{QUESTÃO I}

\section{Como SE yê com a IOAOE QUE TÉ}

\begin{tabular}{|c|c|}
\hline IDÉIAS CENTRAIS & $\begin{array}{l}\text { DISCURSOS DO SUJEITO COLETIVO } \\
\text { (DSCS) }\end{array}$ \\
\hline $\begin{array}{l}\text { Não se sentem com a } \\
\text { idade que têm. }\end{array}$ & $\begin{array}{l}\text { A idade não me afeta em nada, nunca } \\
\text { me afetou. Não me incomoda ter } 60 \\
\text { anos, nem penso nisso. Não consigo } \\
\text { acreditar na idade que eu tenho. A } \\
\text { cultura que a gente tem em relação ao } \\
\text { idoso e muito falha, eu não estou me } \\
\text { sentindo um incapaz, um traste. Me vejo } \\
\text { muito bem. Nunca me preocupei com a } \\
\text { minha idade. Sou muito feliz. Faço o } \\
\text { que nem moça faz. Tenho disposição, } \\
\text { tenho coragem. }\end{array}$ \\
\hline $\begin{array}{l}\text { Percebem a diminuição da } \\
\text { força ocorrida em seus } \\
\text { corpos. }\end{array}$ & $\begin{array}{l}\text { A mesma coisa que eu me via com } \\
20,30,40 \text { anos. Com um pouquinho } \\
\text { menos de força, mas fora isso, } \\
\text { totalmente bem. Me vejo um pouco } \\
\text { mais cansado me vejo bem. Organizei } \\
\text { minha vida: faço ginástica, nado, estudo } \\
\text { na Universidade da Terceira Idade, } \\
\text { tenho rotina excelente. Estou sempre } \\
\text { em contato. Estou feliz. Bem comigo } \\
\text { mesmo. Apesar de vários problemas } \\
\text { que eu estou tendo que enfrentar, mas } \\
\text { estou dando conta. Eu achava que } \\
\text { quando chegasse aos } 60 \text { anos, eu seria } \\
\text { muito idoso, agora vejo que não. Eu } \\
\text { cheguei aos } 60 \text { e ainda tenho bastante } \\
\text { pela frente, né? Me sinto bem, graças a } \\
\text { Deus, me sinto bem. }\end{array}$ \\
\hline
\end{tabular}




\begin{tabular}{l|l}
\hline \multicolumn{1}{c|}{ IDÉIAS CENTRAIS } & $\begin{array}{l}\text { DISCURSOS DO SUJEITO COLETIVO } \\
\text { (DSCs) }\end{array}$ \\
\hline $\begin{array}{l}\text { O corpo não ajuda mas a } \\
\text { cabeça é boa. }\end{array}$ & $\begin{array}{l}\text { Eu me vejo "moleca"(cabeça), mas o } \\
\text { corpo não ajuda, mas eu acho que o } \\
\text { que me ajuda é essa cabeça. A cabeça } \\
\text { é boa, o organismo (corpo) nunca } \\
\text { prestou mesmo, o corpo nunca foi bom. } \\
\text { Estou limitado, não tenho aquela força } \\
\text { fisica de um jovem, desde que foi } \\
\text { detectado a doença de Chagas, em } \\
1962, \text { embora eu me ache um homem } \\
\text { ainda até certo ponto normal. }\end{array}$ \\
\hline Conformação. & $\begin{array}{l}\text { Não tenho mais aquela força física, me } \\
\text { aceito assim mesmo. Eu não reclamo, } \\
\text { porque olha, diz assim, quem já passou } \\
\text { dos 60 tudo sobra, é tudo chance, mais } \\
\text { um dia. Eu sei que o dia de amanhã virá } \\
\text { e se não vier é porque não tem que vir. }\end{array}$ \\
\hline O despertar. & $\begin{array}{l}\text { Fico às vezes assustada de ter } 60 \text { anos } \\
\text { porque pra mim o tempo não passou. } \\
\text { Sinto que não fiquei parada no tempo. } \\
\text { Eu acompanhei bem. Quando os dois } \\
\text { filhos casaram eu me vi cara a cara com } \\
\text { meu problema, comecei a ficar mal. Não } \\
\text { queria mudar para Bragança. Então, } \\
\text { fiquei muito triste, eu tinha vontade de } \\
\text { chorar, depois foi passando. Agora } \\
\text { estou vendo que existem outras coisas } \\
\text { para serem feitas, então já estou } \\
\text { esquecendo os problemas. }\end{array}$ \\
\hline
\end{tabular}




\section{COMENTÁRIOS DA QUESTÃOI}

Quanto à primeira questão proposta no roteiro "como se vê com a idade que tem", os idosos individualmente se vêem bem. Compreendem que a velhice é uma etapa da vida pela qual todos os seres humanos têm que passar, não é uma doença, um problema, uma patologia que os impossibilita de seguirem uma vida normal. Os problemas de saúde para alguns apareceram quando ainda jovens. Assim as avaliações que os idosos fazem sobre esta primeira questão podem ser entendidas como respostas individuais, cada um se "sente bem", negam a visão social generalizada do ser velho declinante, fruto de uma produção da sociedade em que vivem.

Simone de Beauvoir nos fala sobre isso da seguinte forma:

"Em nossa sociedade, a pessoa idosa é designada como tal pelos costumes, pelos comportamentos de outrem, pelo próprio vocabulário: ela tem que assumir essa realidade". (BEAUVOIR, 1990: 357).

Essas avaliações feitas pelos sujeitos entrevistados chamam a atenção para uma idéia de um tempo cronológico que não foi sentido de uma forma linear. Há uma preocupação em destacar um outro movimento temporal interno que não coincide com o externo como nos explica Martins (1998):

"O tempo não é um processo real, uma sucessão de eventos que nos dá prazer em registrar. O tempo origina-se das relações com as coisas em si mesmas. Há um futuro e há um passado que estão em um estado de preexistência etema $e$ de sobrevivência." (p. 13). 
Partindo da premissa de "tempo vivido", o autor ultrapassa a concepção de velhice entendida como última etapa da vida. Para ele, "somos Kairós, isto é, um tempo vivido numa determinação consciente e efetiva de nossa existência. Uma consciência que é tempo e que indica novas direções." (MARTINS, 1998: 16).

Se compreendermos a concepção de Martins, podemos concluir que somos um tempo e imprimimos em cada aspecto de nossa maneira de ser a marca individual e única do tempo que vivemos e do futuro. É fundamental, pois, ampliar os horizontes e possibilidades enquanto vivermos.

Os idosos entrevistados conseguiram se organizar, e agora usam o tempo que é deles para fazer as coisas que anteriormente não tiveram condições de fazer. Com isso tentam mostrar à sociedade e a eles mesmos, que os anos passaram, sem significar que são "velhos incompetentes". 


\section{QUESTÃO II}

\section{o que é ter saúde}

\begin{tabular}{|c|c|}
\hline IDÉIAS CENTRAIS & $\begin{array}{c}\text { DISCURSO DO SUJEITO COLETIVO } \\
\text { (DSCS) }\end{array}$ \\
\hline Saúde é ter disposição. & $\begin{array}{l}\text { É eu acordar de manhã com aquela } \\
\text { disposição para comer, andar, fazer } \\
\text { ginástica. E se sentir bem, ter } \\
\text { disposição para trabalhar, passear, } \\
\text { viajar, dançar. Eu danço, vou em } \\
\text { festas, vou em jantares, é fazer tudo } \\
\text { que eu quero fazer. Sem a saúde você } \\
\text { não faz nada. }\end{array}$ \\
\hline Não sentir dores. & $\begin{array}{l}\text { É não ter dores, não ter problema de } \\
\text { dor de estômago, de cabeça, } \\
\text { financeiro, reumatismo. }\end{array}$ \\
\hline Estar com a mente boa. & $\begin{array}{l}\text { Acho que muito na cabeça, né, mental. } \\
\text { Eu valorizo demais a saúde mental, } \\
\text { porque eu percebi ao longo da minha } \\
\text { vida que um problema fisico, um } \\
\text { câncer, ele atinge o portador, é ele que } \\
\text { vai sentir as dores, e um problema } \\
\text { mental atinge todos da família, né? }\end{array}$ \\
\hline $\begin{array}{l}\text { É continuar integrado à } \\
\text { sociedade. }\end{array}$ & $\begin{array}{l}\text { É poder viver uma vida em sociedade. } \\
\text { Estar de bem com todo mundo, com a } \\
\text { vida, sentir bem no meio que estou. É } \\
\text { participar da vida, sem obstáculos. }\end{array}$ \\
\hline $\begin{array}{l}\text { É continuar vivendo sem } \\
\text { restrições. }\end{array}$ & $\begin{array}{l}\text { Não precisar ficar me restringindo de } \\
\text { muitas coisas, levar uma vida } \\
\text { saudável, poder sair, comer. Fazer as } \\
\text { coisas que gostaria de fazer ou que já } \\
\text { fez anteriormente. }\end{array}$ \\
\hline
\end{tabular}




\section{COMENTÁRIOS DA QUESTÃO II}

Para o idoso, ter saúde é estar em condições de manter o exercício de suas funções sociais e de sociabilidade. É sentir a continuação do funcionamento desse corpo no desempenho de suas funçōes. É poder fazer as atividades, que anteriormente não podiam fazer, devido às suas ocupações com a casa, família, trabalho, é não assumir a condição de velhos incapazes.

Há ênfase no ser ativo, no possuir energia, vêem saúde como elemento fundamental para sentir e viver este momento de suas vidas.

A saúde passa a ter uma conotação de não restrição da vida social dos individuos. Em sendo assim há um "receio", "medo", por parte dos idosos entrevistados de que o "seu corpo visivel para os outros", apresente problemas de "declínio", que haja uma passagem automática do corpo para o espírito, para a mente o que efetivamente impediria a vida social.

Isso tem a ver com o preconceito que marca a velhice nas sociedades industrializadas e modernas, que é sentido pelos idosos que lutam contra esta contradição, ou seja, o que eles vivenciam no próprio corpo e como a sociedade os vê.

De acordo com a reflexão feita por Almeida (1999); "As ações da cultura sobre o corpo não se restringe à sua modelagem externa, à superficie dos corpos individuais. Invadem a interioridade do organismo encontrando-se 
presente nos hábitos alimentares, na higiene e nos cuidados corporais, na sexualidade, no trato com a morte, nas emoções". (p.67).

Em uma cultura que tem como uma das características, o consumo, não é de se surpreender que os sujeitos prestem mais atenção ao seu aspecto, porque ele é uma forma de poder, ou seja, uma forma de mostrar que a vitalidade e a atração física podem ser mantidas, têm maturidade e podem tomar decisões, fazer suas escolhas e lutar por seus direitos. 


\section{QUESTÃO III}

\section{como vé a sua paóptia saúde}

\section{IDÉIAS CENTRAIS
Precisando sempre de manutenção.}

\section{DISCURSOS DO SUJEITO COLETIVO} (DSCs)

Minha saúde é boa, de vez em quando eu faço check-up. Acho que gozo de boa saúde, não tenho empecilhos. 0 organismo, o corpo da gente, necessita de manutenção, periodicamente, a cada 8 ou 10 meses, eu faço os checkups regulamentares. Faço os exames de sangue. Eu tenho mantido o controle da minha saúde de acordo com o pedido do médico. Vou passar por um médico, porque eu quero ver como é que está. Tenho a minha saúde com controle de remédio.

Com dores.

Tenho muitas dores nos braços, mas eu já tinha. Muitas dores, começou, sabe? A dor, esse é o problema, dói muito, nas juntas, ultimamente eu não estou andando, porque está um pouco dificil.

Com problemas que
aparecem com a idade.

Eu mesma estou bem, apesar de uns probleminhas que todos nós temos porque eu não sou mais uma garotinha, tenho problema, por exemplo, de triglicérides, mas eu estou fazendo regime, estou caminhando bastante, já abaixou bastante. Tive um problema no calcanhar, fiz fisioterapia, não curou, essas coisas que vão dizer são características da idade, quando a gente é mais jovem não tem tanto desses problemas musculares. Estou com hérnia de disco, de hiato, são enfermidades que vem com a idade. 


\begin{tabular}{l|l}
\hline \multicolumn{1}{c|}{ IDÉIAS CENTRAIS } & $\begin{array}{l}\text { DISCURSOS DO SUJEITO COLETIVO } \\
\text { (DSCs) }\end{array}$ \\
\hline Emocionalmente ruim. & $\begin{array}{l}\text { Com o casamento do meu filho e a } \\
\text { mudança de São Paulo para Bragança, } \\
\text { eu deprimi, tinha vontade de chorar, } \\
\text { senti dores e cansaço. Estou } \\
\text { precisando dar uma viradinha, já fiquei } \\
\text { muito melhor do meu estado psiquico. }\end{array}$ \\
$\begin{array}{l}\text { Tenho a impressão que não é que a } \\
\text { gente sai de dentro de si própria, vocé } \\
\text { permite que a doença se vá. Eu vejo } \\
\text { que as pessoas se entregam, elas não } \\
\text { reagem e estão cada vez mais doente. }\end{array}$ \\
\hline \multirow{6}{*}{ qunformados com a saúde } \\
quém. & $\begin{array}{l}\text { Limitada, com bastante deficiência, } \\
\text { mas já que eu náo estou hoje com } 30 \\
\text { ou ano anos, vou fazer 70, acho que } \\
\text { está bom. Na minha idade, estou } \\
\text { achando que eu estou bem mesmo de } \\
\text { saúde. Eu me conformo com a minha } \\
\text { saúde, não adianta me revoltar, né? }\end{array}$ \\
\hline
\end{tabular}




\section{COMENTÁRIOS DA QUESTÃO III}

O idoso vê sua saúde normal, como a de qualquer indivíduo, ora com dor, ora sem dor, precisando de cuidados, coisa que não é especifico do velho. Todas as pessoas, desde tenra idade precisam cuidar da saúde, física e mental, ir ao médico e fazer exames rotineiros não é privilégio de um ser que atingiu 60 anos. Há aqueles que arrastam problemas de saúde desde jovens, outros começam a perceber $\circ$ aparecimento de alguns distúrbios em determinado momento da vida, ou seja, com a aproximação dos 60 anos e mais. Enfim para eles, o importante é manter a saúde mental, o que nos leva a pensar que a não aceitação da nova idade e condição de vida possibilite a depressão, a tristeza ou isolamento e isso eles rechaçam, lutam para afastar esse fantasma.

Beauvoir, faz a seguinte afirmação quanto à relação entre doença e velhice:

"Indisposiçōes devidas à senescência podem não ser quase percebidas e passadas em silêncio. São formadas por perturbações superficiais e curáveis. É preciso já ter consciência da própria idade para decifrá-las no corpo. E, mesmo nesse caso, este nem sempre nos ajuda a interiorizar o nosso estado. Tais reumatismos e tal artrite se devem à senescência, sabemos, e no entanto, fracassamos ao tentar descobrir através deles uma nova condição. Permanecemos o que éramos só que com reumatismos a mais". (BEAUVOIR, 1990: 349). 
QUESTÃO IV

\section{A IMPQRTÂHeIA dA UNIUERSIDABE geM RELAĞ̃o à PRÓpria saÚdE}

\begin{tabular}{|c|c|}
\hline IDÉIAS CENTRAIS & $\begin{array}{c}\text { DISCURSOS DO SUJEITO COLETIVO } \\
\text { (DSCS) }\end{array}$ \\
\hline $\begin{array}{l}\text { A Universidade é impor- } \\
\text { tante para a saúde, porque } \\
\text { facilita o convivio com } \\
\text { outras pessoas, possibi- } \\
\text { litando novas amizades. }\end{array}$ & $\begin{array}{l}\text { É gostoso porque eu estou em contato. } \\
\text { Esse convivio é super importante. Vocé } \\
\text { ouve a opinião da outra sua colega, } \\
\text { vocé debate, fala a mesma lingua, } \\
\text { estou no meu ambiente, aprende mais } \\
\text { com pessoas diferentes. Nós temos os } \\
\text { mesmos problemas. Sempre que você } \\
\text { está em companhia de alguém, você } \\
\text { está aprendendo alguma coisa. A } \\
\text { quantidade de pessoas da cidade e } \\
\text { mesmo de Atibaia, tem muita gente que } \\
\text { nós não conhecíamos, então nós } \\
\text { tivemos relacionamento muito grande, } \\
\text { de amizade. Fiz muitas amizades aqui } \\
\text { em Bragança, eu não conhecia quase } \\
\text { ninguém, eu vinha de São Paulo, foi } \\
\text { muito gratificante, eu acho que } \\
\text { Bragança inteira devia se dedicar a } \\
\text { isso, pra esses encontros. Se está em } \\
\text { companhia de outras pessoas, você } \\
\text { consegue outros relacionamentos, é } \\
\text { importantissimo. }\end{array}$ \\
\hline $\begin{array}{l}\dot{E} \text { um estímulo para a } \\
\text { cabeça. }\end{array}$ & $\begin{array}{l}\text { Vim pela vontade de não perder o meu } \\
\text { francês e também estimular o cérebro, } \\
\text { ocupar a cabeça e ter prazer. Descobri } \\
\text { que eu tenho cabeça pra aprender, pra } \\
\text { saúde é ótimo. }\end{array}$ \\
\hline $\begin{array}{l}\text { Manter-se participando e } \\
\text { envolvida com o mundo. }\end{array}$ & $\begin{array}{l}\text { A gente toma parte em tudo, né? Eu } \\
\text { tomo parte no Centro de Aprendizagem } \\
\text { Doméstico (CAD) também, lá viaja } \\
\text { bastante e a gente vai sempre em tudo. } \\
\text { Eu gosto muito de cantar, entáo a gente } \\
\text { sempre toma parte em festas, é bom tá } \\
\text { movimentando, sempre. Quando eu vi } \\
\text { que tinha condições de participar eu vim } \\
\text { e não me fiz de arrogado. }\end{array}$ \\
\hline
\end{tabular}




\begin{tabular}{|c|c|}
\hline IDÉIAS CENTRAIS & $\begin{array}{l}\text { DISCURSOS DO SUJEITO COLETIVO } \\
\text { (DSCS) }\end{array}$ \\
\hline $\begin{array}{l}\text { Importante para a saúde } \\
\text { emocional. }\end{array}$ & $\begin{array}{l}\text { Essas cadeiras que eu fiz, } \\
\text { neurolingüistica e a dinâmica de grupo } \\
\text { me abriram um conhecimento para o } \\
\text { lado emocional. A auto-estima eu acho } \\
\text { que é a tecla mais importante que } \\
\text { precisa ser tocada pelo idoso. Dentro } \\
\text { da sociedade, o velho é estigmatizado, } \\
\text { como traste, uma coisa sem valor. A } \\
\text { medida em que a gente faz alguma } \\
\text { coisa, que recupera a auto-estima todo } \\
\text { o organismo começa a funcionar } \\
\text { melhor. Para a saúde é ótimo porque } \\
\text { sai com a cabeça aberta. Tinha que } \\
\text { pensar em mim, precisava sair daquela } \\
\text { rotina, foi o recomeço de uma vida } \\
\text { melhor, eu acho que me abri, estou me } \\
\text { valorizando mais. }\end{array}$ \\
\hline Romper os estigmas. & $\begin{array}{l}\text { O homem não gosta de vir aqui, não sei } \\
\text { porque, não sei se é machismo, eu } \\
\text { como não tenho preconceito, não tou } \\
\text { nem ai com nada, pra mim foi muito } \\
\text { bom. }\end{array}$ \\
\hline
\end{tabular}




\section{COMENTÁRIOS DA QUESTÃO IV}

O idoso entende que se manter saudável, é continuar na ativa, se movimentando, convivendo com outras pessoas, fazendo novas amizades, criando novas possibilidades, saindo da rotina de casa, rompendo com o estigma imposto pela sociedade que é o da incapacidade. Estarem envolvidos com as instituiçōes que desenvolvem programas para idosos é de fundamental importância para que eles mantenham a saúde equilibrada. Isto vai ao encontro da proposta da OMS quanto à promoção de um envelhecimento saudável, ou seja, preservar a capacidade funcional do idoso e a sua autonomia.

De acordo com Debert, (1996);

"As experiências vividas e os saberes acumulados são ganhos que propiciariam aos mais velhos oportunidades de explorar novas identidades, realizar projetos abandonados em outras etapas da vida." (p.35).

Observa-se, nos discursos dos idosos, o desejo de continuar aprendendo, porque ainda são "capazes de", contrapondo-se às imagens de desinteresse pelas coisas do cotidiano.

A partir de uma primeira classificação dos temas que surgiram após a leitura das entrevistas, sentimos a necessidade de contextualizar as falas que melhor incorporaram o significado dado pelos idosos a cada uma das questões levantadas, nos diferentes momentos que voltaram seu olhar para as mesmas, isso será feito a seguir. 


\subsection{ANÁLISE DAS ENTREVISTAS}

Ao analisar as falas dos idosos, estou levando em consideração a importância das expressões orais oferecidas por eles. "A fala é sempre uma revelação do sentido do SER e do existir do homem, que, enquanto ser, encontra-se no mundo, mas com os outros, partilhando com eles um ser em comum, que vai tornar a linguagem possivel, através da comunicação e expressão". (HEIDEGGER, 1988:49).

Fundamento-me, também, nos pressupostos colocados por Geertz que afirma:

"O que chamamos de nossos dados são realmente nossa própria construção das construções de outras pessoas, do que elas e seus compatriotas se propõem - está obscurecido, pois a maior parte do que precisamos para compreender um acontecimento particular, um ritual, um costume, uma idéia, ou o que quer que seja está insinuado como informação de fundo antes da coisa em si mesma ser examinada diretamente". (1973:19).

Reforçada pela idéia de Geertz quando diz que: "A cultura não é um poder, algo ao qual podem ser atribuídos casualmente os acontecimentos sociais, os comportamentos, as instituições ou os processos; ela é um contexto, algo dentro do qual eles podem ser descritos de forma inteligivel". (1973:24)

Procuro, dessa forma, ouvir os indivíduos sem que se perdesse de vista o caráter histórico e cultural das suas falas, ou seja, nelas estariam contidas 
informações interpretadas e significadas a partir do seu quadro de referência. Em outras palavras, busco interpretar o olhar do idoso para sua própria saúde, sem perder de vista a influência que a cultura exerce no cotidiano dos entrevistados - no caso, como eles vêm seu próprio envelhecimento, a sua própria saúde e sua freqüência à Universidade para a Terceira Idade como mantenedora de saúde.

Dado o convivio com os idosos/alunos em sala de aula, para mim, essa se mostrou como um lugar social de fala, onde as narrativas ali ouvidas e observadas tiveram uma função na construção do significado de saúde para o idoso.

Ao interpretar a fala do idoso, observo basicamente, a singularidade de cada informante e os diferentes pontos de vista. Ressalto as falas para que as mesmas resgatem as diferentes interpretações, a heterogeneidade.

Lopes (1999), em sua tese de doutorado, nos explica que:

"Nessa ótica, mesmo que o investigador parta de algumas hipóteses teóricas, ele estará constantemente atento a elementos que possam emergir como importantes durante o estudo, aspectos, não previstos, dimensões não estabelecidas a priori".(FRANCO, apud LOPES, 1999: p.71).

Entendo, como Lopes (1999) que: "Quando penetramos nas interpretações das entrevistas, aprofundamos significados, incorporando explicações adquiridas através dos sentimentos". (p.65). 
Ao descrever a ocorrência de um certo fenômeno busco o seu significado, a sua expressão no seu contexto cultural. O homem é um animal simbólico e faz uso dos símbolos como uma estratégia para definir situações incompreensiveis: Os símbolos são os mediadores dos significados e, por sua vez, os significados são expressos através dos simbolos, dando seniido ao real. Os elementos simbólicos são fontes de informações sobre os padrões culturais presentes nos processos sociais e psicológicos do comportamento público. Trata-se de apreender, formular e comunicar realidades sociais através de metáforas, continuamente realocadas, que podem mediar significados mais complexos do que sugere a leitura literal.

Os idosos/alunos que participaram deste trabalho representam um grupo diferenciado, pois além de viverem fora da metrópole em cidades pequenas, mais tranqüilas como Bragança Paulista e Atibaia, podem respirar um ar mais puro, não precisam correr tanto, o que já lhes permite sentirem-se mais saudáveis. A qualidade de suas vidas é boa, o que não anula a possibilidade de já terem contraído alguma doença anteriormente. $O$ que parece importante é a forma como eles se vêem e nesse olhar para si está presente o olhar dos outros.

As sociedades criam seus indivíduos que, por sua vez, reproduzem os anseios dessas sociedades e mantêm a ideologia necessária, isto é, seu sistema de crenças e valores, na manutenção dessas mesmas crenças. 
Para Clifford Geertz: "O que o homem é pode estar tão envolvido com o onde ele está, quem ele é e no que ele acredita, que é inseparável deles; ... não existem de fato homens não-modificados pelos costumes de lugares particulares". (1973:47).

$\mathrm{Na}$ fala de $\mathbf{S , 4}$ percebemos a compreensão da influência que a sociedade exerce na vida e conseqüentemente na saúde de cada um:

"Dentro da sociedade, o velho é estigmatizado, como traste, uma coisa sem valor. A medida em que a gente faz alguma coisa que recupera a auto-estima todo o organismo começa a funcionar melhor".

S,5 também nos aponta para este fato:-

"O homem não gosta de vir aqui, não sei porque, não sei se é machismo, eu como não tenho preconceito, não tou nem ai com nada, pra mim foi tudo bom".

S,4 também, nos diz que:

"A cultura que a gente tem em relação ao idoso é muito falha, eu não estou me sentindo um incapaz, um traste".

Christopher Lasch (1983) "entende que apesar de nossa sociedade inspirar-se nos principios do respeito e da amizade, ela define os idosos como inúteis, força-os a se aposentar antes de ter exaurido sua capacidade para o trabalho e reforça seu senso de superfluidade em todas as oportunidades... Ao desvalorizar a experiência e dar muito valor à força física, destreza, adaptabilidade e a capacidade de surgir novas idéias, a 
sociedade define a produtividade em modos que automaticamente excluem os cidadãos mais velhos". (p. 253).

A cultura brasileira tende a valorizar o jovem e o que é novo. É uma cultura mais preocupada em incorporar as últimas novidades produzidas no exterior do que em olhar para suas próprias tradições. A idéia de um pais sem memória que despreza seu passado, é a prova do descaso com que o idoso é tratado pela sociedade. (DEBERT, 1996:38).

Uma outra fala significativa é a que diz respeito ao tempo.

"Não consigo acreditar na idade que tenho". $(S, 4)$

"A mesma coisa que eu me via com 20, 30,40 anos". (S,11)

"Eu achava que quando chegasse aos 60 anos, eu sena muito idoso, agora vejo que não". $(\mathbf{S}, \mathbf{1 0})$

"Fico às vezes assustada de ter 60 anos, porque pra mim o tempo não passou. Sinto que não fiquei parada no tempo". $(\mathbf{S}, \mathbf{8})$

Segundo Martins (2000):

"A idéia de velhice, terceira idade ou ancião, tem-se resolvido em substantivos e até mesmo em adjetivos para designar a postura do humano numa sociedade de classes que o vê de uma determinada forma. A existencialidade porém é que é, em si mesma, a estrutura essencial do ser humano". (p. 11).

Não há como isolar os acontecimentos da vida do ser humano, pois a idéia de eventos ou acontecimentos são recortes feitos por um observador finito. "O tempo não é um processo real, uma sucessão de eventos. O tempo origina-se das relações com as coisas em si mesmas". (MARTINS, 2000:13). 
Os idosos não pararam no tempo para olharem para si mesmos e fazerem a separação entre o que passou, o que está sendo vivido e o que ainda virá a ser vivido. Na vida das pessoas não há como fazer esta ruptura, não há como definir em termos de tempo onde inicia-se a adolescência, a juventude, a velhice. Há uma trajetória que se percorre ao longo dos anos. Assim quando busco minhas lembranças estou olhando o meu passado, o que estou vivendo agora é o meu presente e quando lanço mão de projetos, olho para o meu futuro.

"É na cotidianidade da vida, naquilo que fazemos, que vivemos, no nosso trabalho, no honzonte do dia que terminou, no dia e na noite, é aí que se estabelece o contato com o tempo e, então, aprende-se a conhecer o seu curso". (MARTINS, 2000:17)

Com relação à saúde do idoso existe a possibilidade de se estabelecer uma cronologia em termos de passado, presente e futuro. Podemos observar este dado nas falas de:

"Minha saúde é boa, tenho um pouco de gastrite, eu herdei do meu tempo de São Paulo". $(S, 1)$

"Tenho muitas dores nos braços, mas eu já tinha". $(\mathbf{S}, \mathbf{2})$

"A cabeça é boa, o organismo (corpo) nunca prestou mesmo, o corpo nunca foi bom". $(\mathbf{S}, 7)$

"Não tenho aquela força física de um jovem, se eu não tivesse a doença de Chagas, foi detectado pela $1^{a}$ vez em 1962". (S,9) 
Buscando as anotações feitas no diário de campo tive condições de rever em minha memória como S,7 e S,9 falaram de si mesmo. S,7 na juventude, sofreu um atropelamento e teve que se submeter ao longo dos anos a 10 cirurgias. S,9 morava no interior e muito jovem foi picado pelo barbeiro, contraindo a doença de Chagas.

Esses idosos não esperaram que o tempo passasse, que a velhice chegasse para contrair um problema qualquer de saúde. No caso dos citados, o problema de saúde foi adquirido anterior à fase de envelhecimento, conviveram com a doença, convivem com ela e essa Ihes acompanhará no futuro.

Revejo, ainda, o caminhar de $\mathbf{S , 7}$ com muita dificuldade pelos problemas da coluna e também a gordura. Seu semblante mostrava uma dor incômoda, mas ela não se entregava, brincou todo o tempo que nós conversamos provando que ela não era "doente", nem "velha", que apenas estava sofrendo as conseqüências do acidente sofrido. Mostrava-se muito envolvida com as atividades do seu cotidiano.

Ser idoso não significa ser doente. Entendo a saúde como um estado natural. Ela está presente em nós como manifestação da fluidez de energia em nosso ser. É estarmos em equilibrio com a natureza e com nós mesmos.

É claro que há o desgaste das células, do corpo físico, mas não uma conseqüencia do descuido pessoal. "O envelhecimento traz consigo uma maior chance de aparecimento de doenças, que não aquelas que à arecem 
nos jovens, como os problemas vasculares, arteriais ou venosos, a osteoporose e outros, que poderiam ser chamados doenças próprias do envelhecimento, na medida em que refletem o desgaste de diversos órgãos do corpo humano." (BERES, 1994: 11).

"O contingente de adversidade das coisas cresce: as escadas ficam mais duras de subir, as distâncias mais longas a percomer, as ruas mais perigosas de atravessar, os pacotes mais pesados de carregar. O mundo fica eriçado de ameaças, de ciladas ". (Bosi, 1987:37).

Envelhecer sem nenhuma doença crônica é antes exceção do que regra. No entanto, a presença de uma doença crônica não significa que o idoso não possa gerir sua própria vida e viver o seu dia-a-dia de forma independente.

Podemos detectar este fato nas falas dos idosos:

"Muitas dores, começou sabe? $(\mathbf{S , 8 )}$

"Estou com muita dor nas juntas, ultimamente eu não estou andando, porque está um pouco difícil". $(\mathbf{S}, 9)$

"Eu mesma estou bem... apesar de uns probleminhas que todos nós temos, porque eu não sou mais uma garotinha". (S,3)

"Tive um problema no calcanhar, fiz fisioterapia, não curou, essas coisas que vão dizer são características da idade, quando a gente é mais jovem não tem tanto desses problemas musculares". $(\mathbf{S}, \mathbf{4})$

"Atualmente eu tenho problemas que eu não tinha quando era mais nova, né? $(S, 12)$ 
"Estou com hérnia de disco, tenho hérnia de hiato, são enfermidades que vem com a idade". $(\mathbf{S}, \mathbf{1 2})$

A saúde na velhice parece estar relacionada com aspectos físicos anteriores, vividos na juventude e na idade adulta, e com a capacidade de relativizá-los no cotidiano atual. "O corpo do idoso configura una comunicação entre o interior e o exterior. Conhecer o corpo implica compreendê-lo como suporte ou condição para o exercício das funções sociais. O velho envolvido num mundo onde o que vale é a produção, sem acesso às sutilezas da biologia, facilmente relaciona seu corpo que não apresenta a performance jovem com uma máquina que não funciona bem." (ALMEIDA, 1999: 66).

É interessante a fala de S,2 quando lembra o conselho de sua professora de ioga a respeito do convivio e aceitação da dor: "A minha professora de ioga citou uma coisa importante - trate a dor, como uma visita indesejável quando vocé gosta de uma visita, você dá cafezinho, biscoitinho, a visita fica bastante tempo. Agora, se você não trata bem a visita, ela logo vai embora. Então trate a dor como uma visita indesejável". $(\mathbf{S}, \mathbf{2})$

Debert nos mostra que:

"Os individuos são não apenas monitorados para exercer uma vigilância constante do corpo, mas são responsabilizados pela sua própria saúde. A publicidade, os manuais de auto-ajuda $\theta$ as receitas dos especialistas em saúde estão empenhados em mostrar que as imperfeições do corpo não são naturais nem imutáveis, e que, com esforço e trabalho corporal disciplinado, 
pode-se conquistar a aparência desejada, as rugas ou a flacidez devem ser tratadas com a ajuda de cosméticos, de ginástica, das vitaminas, da indústria do lazer". (1996:37).

Na fala de alguns dos idosos percebemos a preocupação em manter o corpo em atividade, se movimentando, fazendo coisas que thes proporcionam prazer.

"Organizei minha vida: faço ginástica, nado, estudo na Universidade da Terceira Idade". $(\mathbf{S}, \mathbf{1})$

"Ter saúde é eu acordar de manhã com aquela disposiçăo para comer, andar, fazer ginástica".(S,1)

"É ter disposição para trabalhar, para passear, para viajar, dançar. Eu danço, vou em festas". (S,6)

Entendemos que: “O corpo não se resume à sua materialidade física: mais do que um fato da natureza, ele é um produto da época e do lugar. As sociedades apropriam-se do corpo com o objetivo de afirmarem algo que não está nele; fazem-no para expressar disposições sociais e valores culturais". (ALMEIDA, 1999: 65).

A falta de energia, ou seja, sentir cansaço significa a passagem do tempo pelo corpo.

Os depoimentos abaixo ilustram esta afirmação:

"Me vejo um pouco mais cansado, me vejo bem". $(\mathbf{S}, \mathbf{1})$

"Eu acho que a gente deve envelhecer, mas não ir perdendo as forças". (S, 12) 
"Estou limitado, não tenho aquela força física de um jovem". $\mathbf{( S , 9 )}$

Segundo nos explica Mercadante, (1997): "Um corpo bem disposto, com saúde conseguido através de exercícios físicos, cuidados clínicos, é um sinal evidente do não declínio físico, de não-velhice". (p. 190).

Essa avaliação aparece em algumas falas transcritas abaixo:

"Ter saúde é eu acordar de manhã com aquela disposição para comer, andar, fazer ginástica". $(\mathbf{S}, 1)$

"O organismo, o corpo da gente, necessita de manutenção". $(\mathbf{S}, 4)$

"Periodicamente, a cada 8 ou 10 meses eu faço os checkups regulamentares". $(\mathbf{S}, 5)$

"Eu não estou sentindo nada, vou passar por um médico porque eu quero ver como é que tá". $(\mathbf{S}, \mathbf{6})$

O desejo de liberdade, principalmente de tempo, é explicitado pelos entrevistados. Criar seu próprio tempo, sem horários rígidos, viajando, dançando, freqüentando a Universidade para a Terceira Idade, visitando amigos, são temas postos nas falas dos alunos/idosos de forma prazerosa, não rotineira. Para eles essa liberdade tem um significado extremamente importante que é o de ter saúde física e mental e isso lhes permite ter raciocínio próprio, ou seja autonomia para fazer escolhas, se locomoverem e principalmente sentirem-se envolvidos com a sociedade da qual fazem parte.

Percebemos isso em algumas falas: 
"É gostoso porque eu estou em contato. Esse convivio é super importante". $(\mathbf{S}, \mathbf{1})$

"Vim pela vontade de não perder o meu francês e também estimular o cérebro". (S, 2)

"Para a saúde é ótimo, porque sai com a cabeça aberta". $(\mathbf{S}, 5)$

"Esse aprender me deu essa melhor saúde para continuar aprendendo, prá descobrir que eu tenho cabeça pra aprender". $(S, 13)$

"Tinha que pensar em mim. Eu precisava sair daquela rotina, aquilo estava me levando prá ficar louca. Foi o recomeço de uma vida melhor". $(\mathbf{S , 8 )}$

É na definição da velhice como etapa da reflexão, que se explicita uma outra face da velhice, a sabedoria. Ela emerge como um atributo inalienável do velho, mesmo nas situações de déficit ou auséncia de educação formal.

Algumas falas ilustram esta questão:

"Me sinto mais madura, muito mais sábia. Aquela ânsia que movia a gente prá viver, ela está tranqüila, eu sei que o dia de amanhã virá e se não vier é porque não tem que vir". $(S, 13)$

"Quando eu voltei a trabalhar, eu tinha 45 anos, e eu justamente consegui este posto pela minha idade, pela experiência que eu tinha, e eles não queriam uma jovenzinha, então eu achei que eu tava preparada, eu achei que foi por causa da idade, então a idade eu acho maravilhosa". (S,1)

As alusões à sabedoria, à experiência, soam paradoxais, se pensadas a partir de um modelo de sociedade que nega a experiência, substituindo-a 
pela informação, que valoriza o novo, alimentando-se do princípio da eterna mudança.

Segundo Almeida, 1999:

"A sabedoria atribuida ao idoso está situada em outro lugar, lugar distante dos livros, das informações e atualizações, mobiliza menos razão e mais sensibilidade. Esta sabedoria representa a aquisição, lenta e progressiva, de uma "teoria de vida". O velho é sábio porque, "já viveu, já experimentou, já desvendou os segredos que todos buscam". (p.146).

Birman, 1995, nos diz que:

"Na atualidade se processam transformações importantes nas relações estabelecidas pela sociedade com a velhice na nossa tradição cultural. A velhice passa a ser objeto de cuidado e atenção especiais. Parece que começou a se realizar no Brasil, de maneira lenta um processo que indica uma reviravolta importante na relação de nossa cultura com a velhice... ela passa a receber um olhar e um inicio de reconhecimento social que não existe na memóna da modemidade". (p. 35/36).

É importante que se tracem estratégias que permitam melhor aproveitamento do tempo livre e aumento na qualidade de vida, assim como atitudes e politicas positivas, alternativas à discriminação contra os idosos. No entanto, o mais importante é que essas estratégias tornem-se efetivas, bem como as políticas sociais, de saúde, trabalho e culturais que permitam o continuo aproveitamento e a participação social dos idosos marcadas pela dignidade e respeito que merecem, sentindo, assim, que suas vidas têm significado 


\section{INTERPRETAÇÕES DO PESQUISADOR}




\section{INTERPRETAÇÕES DO PESQUISADOR}

Esta pesquisa teve por objetivo buscar o significado que o idoso dá para a sua própria saúde. A mesma esclarece, a partir dos dados obtidos junto aos idosos entrevistados, a representação do que configura "ser velho", "ter saúde", "o significado de sua própria saúde" e "a freqüência à Universidade para a Terceira Idade. Os dados obtidos não estão fechados em si mesmos, de uma vez que, a maneira de se ver as coisas estão sempre em movimento, não são estanques. A sociedade embora esteja alicerçada por sua cultura se transforma, se modifica e evolui.

Dessa forma, teço algumas interpretações a partir do olhar do sujeito idoso.

No decorrer da pesquisa, percebo que para os idosos entrevistados, a velhice não significa estar ou ser doente, percebem as alterações fisicas que acontecem nesse processo, tornam-se mais lentos, com menos força, menos ansiosos e mais sábios (maduros).

Certamente,sabemos que não se tem só idosos sadios, nem todos os idosos são doentes. Dentre os entrevistados encontramos aqueles que desde tenra idade convivem com problemas de saúde fazem tratamento, sentem dores, mas não se vêem impossibilitados de estarem envolvidos com as atividades que Ihes dão prazer. Sentem-se saudáveis! Dançam, cantam, aprendem línguas e computação. 
Os depoentes assimilam a saúde a uma postura ativa frente às dificuldades do meio fisico, psiquico e social. Ela passa a ser vista como expansão da vida.

Para esse segmento da sociedade, saúde também é sinônimo de ir e vir com facilidade, de lazer, de alimentação balanceada e de não sofrer dor fisica

O idoso vê sua própria saúde como uma condição de "sentir-se bem". Isto significa para eles, mobilidade, autonomia, equilibrio emocional, alegria por serem capazes de aprender, passear e viajar. É uma desobrigação com o tempo, este tempo que eles não sentiram passar e nem cronometraram, por essa razão se assustam quando param e se dão conta que ele foi passando.

As idas às consultas médicas representam uma prevenção, ou seja, dar manutenção ao corpo que como uma máquina precisa ser olhada de vez em quando para ver como está o seu funcionamento.

Os entrevistados apontam para a influência da cultura quanto à maneira de se olhar o idoso. Há uma preocupação quanto ao estigma que a sociedade impõe aos velhos, essa os vê de forma excludente. Daí a expectativa vivenciada por eles de como seria chegar aos 60, 65, 70 anos. Hoje, já se vêem diferentes e assumem isso.

Os idosos sinalizam, também, para o "mal-estar" que Ihes causaram a saida de seus filhos de casa. Chegaram a se deprimir, se sentiram sem 
ânimo, doentes. Conseguiram romper essa barreira buscando, fora de casa, alternativas para modificarem suas rotinas. Buscaram a Universidade para a Terceira Idade com o intuito de sair das atividades cotidianas: as mulheres do gerenciamento da casa, os cuidados com o marido e com os netos. Os homens buscam sair da inatividade, ficar em casa fazendo pequenos serviços ou vendo televisão é algo que os incomoda, e muito, pois quando estavam trabalhando adquiriram o hábito de estar sempre fora dela. Enfim, perceberam que poderiam fazer novas amizades, continuar vivendo a vida com qualidade.

Para os idosos/alunos saúde é tudo em suas vidas. Isso significa se sentirem dispostos desde o início do dia, é principalmente não ter dores, é participar da vida em sociedade sem obstáculos. Isso significa que não querem estar sozinhos, sentem necessidade de se envolverem com as atividades sociais para garantirem o distanciamento da solidão.

Há entre eles uma preocupação muito grande com a saúde mental, não querem perder a autonomia, o direito de tomarem suas próprias decisōes e não dependerem da familia.

A convivência com outras pessoas da mesma faixa etária, as trocas de experiências, a possibilidade de aprender coisas novas, para eles é extremamente saudável. Entendem que a idade não Ihes incapacitou e ainda podem aprender computação, dizer "não", uma vez que ao longo de suas vidas esse fato thes parecia impossivel. O "sim" que diziam muitas vezes 
tinha significado oposto. Essa experiência "saudável", segundo os idosos/alunos pôde ser vivida na Universidade para a Terceira Idade, que é vista como um espaço de participaçăo onde eles se revitalizam.

Para os idosos que participaram desta pesquisa, a saúde está relacionada com a sensação de maturidade pelos saberes acumulados e pelas experiências vividas. Não pararam no tempo, rechaçam o que a sociedade Ihes impõe, a incapacidade, a exclusão, embora esses sejam elementos que se refletem em sua saúde. Como professores ou profissionais de saúde, devemos ver o idoso como fonte de recursos, um ser ativo, capaz de oferecer respostas criativas ao conjunto de mudanças sociais que redefinem a experiência do envelhecimento. É preciso entendêlos enquanto sujeitos históricos que podem intervir através de sua ação no processo sócio-político. É preciso compreender sua importância, enquanto um ser que constrói conhecimento e que o compartilha com a sociedade.

Essas foram algumas das interpretações a que chegamos, ulterior às análises dos diversos fatores implicados no olhar do idoso para sua própria saúde. 
CONSIDERAÇÕES

FINAIS 


\section{CONSIDERAÇÕES FINAIS}

Este trabalho foi realizado com o objetivo de contribuir com uma reflexão sobre o significado que o idoso dá à sua própria saúde. Sua finalidade é possibilitar ao idoso se desvelar quanto às suas questões de saúde. Para alcançarmos este fim pesquisamos o idoso que freqüenta a Universidade para a Terceira Idade na Universidade São Francisco, campus de Bragança Paulista.

Neste trabalho, procuramos levar o idoso/aluno a voltar seu olhar para si mesmo, bem como dar-Ihe oportunidade de falar e ser ouvido.

Para isso, levamos os entrevistados, em primeiro lugar, a olharem para sua idade e, em seguida, para a sua saúde, para finalmente levá-los à reflexão sobre a importância, para sua saúde, do engajamento em uma determinada instituição que promove atividades para os idosos.

O que encontramos através das falas de cada um deles é que eles estão em um contexto sócio-político-cultural, onde a velhice é institucionalizada a partir dos 60 anos de idade. Este é um parâmetro cronológico que define quando a pessoa é considerada velha. Sobre esse critério, afirma Moragas (1997):

"A definição da velhice através da idade cronológica permite uma concepção individualizada do que seja uma pessoa idosa no final do século $X X "$ ". (p.26). 
O que observamos é que esses idosos/alunos se surpreenderam ao olhar para sua idade, a disposição que sentem, a vontade de viver, de continuar lutando, envolvidos com o grupo social do qual fazem parte.

Quando iniciei este trabalho imaginava que esses sujeitos idosos somente reproduziriam as idéias sociais sobre a velhice e a saúde/doença e não a negassem como as falas apontam.

A cultura brasileira, conseqüência da industrialização, construiu um perfil de idoso como improdutivo, incapaz, aquele SER que se aposentou, recebendo uma quantia irrisória, que mal dá para sobreviver, que deve cuidar dos netos para possibilitar aos filhos produzirem fora de casa, ou seja, fazerem parte do mercado de trabalho e com isso competirem por melhores colocações e salários

Os idosos percebem que "ser velho em nossa sociedade é lutar para continuar sendo homem, é sobreviver sem projeto, sofrendo as adversidades de um corpo que se desagrega à medida que a memória vai-se tornando cada vez mais viva". (BOSI, 1995, p.18).

Com a evolução da nossa sociedade já se percebe mudanças neste perfil. O idoso hoje, assume um papel participativo no seio da sociedade, não estão disponiveis para a familia, para o lar. A partir do momento em que eles se envolvem com atividades fora de casa e o número de idosos, que têm se libertado desta forma de exclusão social tem crescido muito, eles passam a 
identificar novos caminhos, novos horizontes e conseqüentemente vêem preservada sua saúde.

Os entrevistados representam um grupo diferenciado que tem consciência do estigma que thes é imposto pela cultura da sociedade onde vivem, mas rechaçam essa imposição, tentando mostrar que estão saudáveis, têm condições de fazer projetos, não aceitam a condição de doentes, improdutivos, sem autonomia para gerirem sua próprias vidas e seus desejos. A eles não foi perguntado o que gostariam de fazer depois de aposentados. Cuidar dos netos? Não! A eles foi concedida a responsabilidade de educar e encaminhar os filhos, renunciaram aos estudos, ao lazer, às viagens, aos cuidados com sua própria saúde, enfim este é o momento de cada um deles. A obrigatoriedade da administração da casa e de suas vidas não quer ser olhada como peso, mas, sim, com prazer. Nesta etapa da vida, o arquétipo predominante deve ser o do sábio, da sabedoria, aquela que só com o passar dos anos, é dada a conhecer. É a riqueza acumulada pelas experiências vividas. É através da ativação desse arquétipo que a pessoa se "abre" para si mesma, para o outro e para a cultura, dando a conhecer uma forma nova de se relacionar com o mundo em "si" e o mundo "para si".

Segundo Assmann, (1998):

"A vida é, basicamente, uma persistência de processos de aprendizagem. Seres vivos são seres que conseguem 
manter, de forma flexivel e adaptativa, a dinâmica de continuar aprendendo". (p.22).

O que se percebe é que esses "seres aí que comparecem" às aulas em uma Universidade para a Terceira Idade, estão reivindicando um espaço que possibilite o afloramento de sua personalidade - "o self", do qual surjam tova a criatividade, beleza, sentido e principalmente o forte sentimento de fazer parte, de não estar sozinho.

Usar o tempo livre como nos indica De Masi (2000) em seu livro o "Ócio Criativo", ou seja: "libertar-se da idéia tradicional do trabalho como obrigação ou dever e apostar numa mistura de atividades, onde o trabalho se confundirá com o tempo livre, com o estudo e com o jogo". (p.8).

Aspectos éticos das relações sociais trazem à tona o debate em torno da promoção da saúde: pensar no bem-estar ou na qualidade de vida do idoso é pensar na promoção da saúde e, em decorrência, buscar maneiras de adiar ou minimizar sofrimentos que podem advir com o envelhecimento.

No atual debate da promoção da saúde se aponta para a criação de possibilidades sociais adequadas à promoção da saúde dos idosos. No entanto, essa não garante uma velhice isenta dos processos degenerativos. Não existe nenhum modelo que possa ser imposto como condição de vida saudável. Para se alcançar uma velhice saudável é preciso promover a saúde durante toda a vida do individuo, porque o envelhecimento não 
começa aos 60 anos, mas é o acúmulo e a interação de processos sociais, de saúde e de comportamentos de toda a vida.

Acredito ser importante considerar os idosos como participantes ativos na sociedade e para reforçar, cito o documento lançado para o Plano de Ação sobre Envelhecimento, aprovado em Viena pelas Nações Unidas, que oferece a base para um enfoque na promoção da saúde.

"O Comitê Executivo enfatizou o papel de liderança da OPAS na promoção da saúde ao longo do ciclo da vida e a necessidade de se concentrar nas seguintes prioridades: fortalecer a capacidade dos serviços primários de saúde para atender as necessidades de uma população idosa em rápido crescimento, fortalecer os recursos familiares para cuidado dos idosos e promover a integração social dos idosos". (25 Conferência Sanitária Pan-Americana, 1998, p.3).

A boa qualidade de saúde não depende só dos esforços individuais dos idosos. Para garantir uma boa saúde, é preciso haver condições minimas de dignidade na velhice, a fim de que o sujeito se sinta valorizado como ser humano e motivado a desenvolver cuidados pessoais.

Nas falas dos idosos percebemos que a freqüência à Universidade para a Terceira Idade é importante para mantê-los saudáveis. Lá encontram recursos e oportunidades para mostrarem seu valor, sua criatividade é explorada e se manifesta como potencial humano existente entre eles. melhorando sua qualidade de vida. 
Quando não há possibilidade de expandir essas capacidades, resta voltar a atenção para as perdas físicas e torná-las objeto de atenção constante, devido à perda da auto-estima.

Os idosos que freqüentam a Universidade para a Terceira Idade são aqueles que estão desempenhando seu dia-a-dia de modo autônomo e independente, portanto, idosos saudáveis para sua faixa etária - não representando, assim, o universo de idosos hospitalizados ou enfermos, nem de UATIs! ${ }^{5}$ As políticas de manutenção da saúde e qualidade de vida devem se voltar para os idosos que estão com sua saúde preservada, no sentido de evitar o surgimento de doenças, e a conseqüente perda da qualidade de vida.

Se hoje há Universidades para a Terceira Idade, devido ao aumento da população idosa no mundo, por outro lado, elas existem porque há um segmento da população, que sente necessidade de viver de forma participativa, desenvolvendo sua dimensão psiquica, em confronto com uma mentalidade "esclerosada", de que a pessoa idosa não tem mais para onde ir, a não ser continuar representando o papel que a sociedade the impõe.

A frequêencia a lugares públicos ou privados induz à participação em novas atividades suscitando, assim, o sentimento de pertencer a um espaço e a um grupo caracterizados pela vontade de envelhecer ativamente, criando um novo emprego do tempo livre: Conquistando espaços de informação e

\footnotetext{
${ }^{5}$ UATIS - Universidade para a Terceira Idade
} 
sociabilidade os idosos mudam a representação que thes é habitualmente imposta: a imagem de uma velhice monótona, sofrida, dolorida, doída, estereotipada. Essa imagem perde aos poucos sua força e se desfaz.

O idoso que busca se envolver em programa como a Universidade para a Terceira Idade, tem outras expectativas além daquela de aprender, ele tem a expectativa de conviver. A convivência não deve ser feita apenas num modelo de sala de aula, mas no modelo de experiências, vivências comuns, uma vez que um ambiente saudável propiciará, ao idoso, maior bem-estar.

Entendemos que a exclusão do idoso da vida social reflete negativamente em sua saúde. A sociedade deve mudar sua forma de olhar 0 idoso, é necessário que o velho não seja estigmatizado pela mídia e pela própria sociedade. Não haverá mudança cultural, se não houver rompimento de comportamento embora com dor e com luta.

O importante é que, cada vez mais segmentos da sociedade brasileira incorporem e se interessem pelas questões do idoso. Portanto, todas as experiências, das mais simples às mais sofisticadas, serão bem-vindas, pois ajudarão a resgatar a verdadeira cidadania desses SERES idosos

As instituições de ensino devem contribuir cada vez mais para a promoção da saúde dos idosos, abrindo espaços onde os mesmos possam se envolver em atividades que Ihes proporcionem prazer e bem-estar e se sintam como cidadãos ativos e saudáveis. 
Esperamos que este material, cujo tema é amplo, cheio de nuances, principalmente por focalizarmos a saúde do próprio idoso e sabendo que sobre cada um recai toda uma influência vinda da cultura da qual fazem parte, desperte $o$ interesse de outros pesquisadores a estudar aspectos da saúde do idoso e assim abrir perspectivas para um novo modo de ser $€$ se ver. Mais uma vez retomo Geertz quando nos diz que os significados estão em constante mutação, portanto, esta análise continua incompleta, cabendo aos pesquisadores do tema continuar o estudo dos significados que o idoso dá à sua saúde. 


\section{BIBLIOGRAFIA CONSULTADA}




\section{BIBLIOGRAFIA CONSULTADA}

1. Almeida VLV. Visualidade e Mundo Moderno: Imagens da Velhice. São Paulo; 1999. [Tese de doutorado em Ciências Sociais - PUC].

2. A Casa da Morte. Rev. Veja. São Paulo; 1996: Ano 29, nº 23.

3. Andriolo A. Representações Sociais de Mulheres Idosas Sobre Alimentação. São Paulo; 1999. [Tese de Mestrado - FCF / FEA / FSP da USP].

4. Araujo MHC de. O “Dasein" de Heidegger, O Personalismo de Mounier e o S. Social. In: Debates Sociais - CBCISS - Rio de Janeiro; 1980. No 30 , Ano XVI, p. 11-21.

5. Assmann H. Reencantar a Educação - Rumo à Sociedade Aprendente. Petrópolis; 1998.

6. Bardin L. Análise de Conteúdo. Edições 70, Lisboa; 1994.

7. Berlinck M. A Envelhescência. Psicologia do Envelhecimento, Boletim de Novidades; 1996. Ano IX, N 91, p. 5-11.

8. Beaini CT. Questões Fundamentais sobre a Linguagem no Pensamento de Martin Heidegger. São Paulo; 1980. [ Dissertação de Mestrado - PUC]

9. Beauvoir S. A velhice. São Paulo: Difusão Européia do Livro; 1976.

10. --..- A Velhice - Tradução Ma. Helena Franco Monteiro. Rio de Janeiro; Nova Fronteira, 1990.

11. Barell V, Kaplan G. Etnic differences among the aged. Gerontology, 3: 25-37, 1982.

12. Beres VLG. "A gente que tem o amarelão tem que se conformar" A atenção à saúde na perspectiva dos Idosos. São Paulo; 1994. [Dissertação de Mestrado em Psicologia Social, PUC]. 
13. "Quando nos tornamos velhos? Aspectos Internos e Externos desta questão". São Paulo; 1999. [Doutorado em Psicologia, USP]

14. Berger PL, Luckmann T. A Construção Social da Realidade, Petrópolis: Vozes; 1999.

15. Berquó ES. Fatores Estatísticos e Dinâmicos - Mortalidade e Fecundidade. In: Santos JL et al., organizadores. Dinâmica da População: teoria, métodos e técnicas de análise. São Paulo; 1986.

16. -.... Algumas Considerações Demográficas sobre 0 Envelhecimento da População no Brasil. Trabalho apresentado no Seminário Internacional sobre Envelhecimento Populacional. 1996; julho; Brasilia.

17. Bicudo MAV. A percepção em Edmundo Husserl e em Maurice Merleau-Ponty. Rev. Veritas. Porto Alegre; 1997; $n^{0} 1$, p.79-95.

18. -_- Cunha VH. - Pesquisa qualitativa em Educação - Unimep - $2^{a}$ ed. Piracicaba - SP.

19. Birman J. Futuro de todos nós: Temporalidade, Memória e Terceira Idade na Psicanálise. In: Terceira ldade, um envelhecimento digno para o cidadão do futuro. UNATI/UERJ, Relume / Dumará. Rio de Janeiro; 1995.

20. Bosi E. Memória e Sociedade: Lembrança de Velhos. $2^{\text {a ed. São }}$ Paulo: TA Queiroz; 1987.

21. Memória e Sociedade: Lembranças de Velhos $4^{\text {a }}$ ed. São Paulo: Companhia das Letras; 1995.

22. Bourdieu P. A miséria do mundo. Petrópolis: Vozes; 1998.

23. O Poder Simbólico. $2^{\mathrm{a}}$ ed. Rio de Janeiro: $3 C D$ União Editoras; 1998.

24. Brasilia. Decreto Lei $N^{\circ} 8842$, de 4 de janeiro de 1994. Sanciona a Política Nacional do Idoso. Diário Oficial da União 
25. Brito FC Auto-avaliação de saúde do idoso versus avaliação médica: um estudo de concordância. São Paulo; 1997. [Dissertação de Mestrado, Escola Paulista de Medicina, Universidade Federal de São Paulo].

26. Bubber M. Eu e Tu. São Paulo: Cortez e Moraes; 1979.

27. Bueno $\mathrm{F}$ da S. Org. Dicionário Escolar de Língua Portuguesa. Min. Ed. e Cultura. $11^{\text {a }}$ ed. Rio de Janeiro; 1980.

28. Callis LL. A Velhice em Diferentes Culturas. Rev. Via Vida. 1996; São Paulo: TED ed.; p.23-26.

29. Camargo ABM, Saad PMA. Transição Demográfica no Brasil e seu Impacto na Estrutura Etária da Produção. In: O Idoso na Grande São Paulo. Coleção Realidade Paulista. Fundação SEADE. São Paulo; 1990.

30. Canquilhem G. Le Normal et le Pathologique. Presses Universitaries de France; 1972.

31. Capalbo C. Fenomenologia e Serviço Social - in Debates Sociais CBCISS - Rio de Janeiro; 1984. № 38, Ano XX, p. 23-39.

32. Carvalho AS. Metodologia da entrevista - Uma abordagem Fenomenológica. Rio de Janeiro: Agir; 1987.

33. Carvalho Filho ET de, Papaléo Netto M. Geriatria. São Paulo: Atheneu; 1994.

34. Castanheira ERL, Teixeira RR, Lima AMM. Envelhecimento e Ação Programática da Necessidade à Construção de um Objeto: em programação em Saúde Hoje. In: Schalber LB. org. $2^{\text {a }}$ ed. São Paulo: Hucitec; 1993; p. 183-226.

35. Cecilio LCO. (org).Saúde em Debate. Série Didática 3, São Paulo: ABDR; 1995

36. Clinica Santa Genoveva: Idoso Vitima. Folha de São Paulo. São Paulo: julho/96, p.3-12. 
37. Cohn A. Construção e Prática em Saúde Coletiva. $O$ desafio Permanente. Rev. Saúde e Sociedade. 1992; № 2, Faculdade de Saúde Pública da USP - Associação Paulista de Saúde Pública.

38. Confort A. A Boa Idade. Rio de Janeiro: Difel; 1979.

39. Coni N, Davison W, Webster S. O Envelhecimento - Tudo o que você precisa saber sobre. São Paulo: Experimento; 1996

40. Correa JA. L'Evolution de la Notion du "Corps" a la Notion de "Chair"chez Maurice Merleau-Ponty. Belo Horizonte: Kriterion: 1972. vol. $19, n^{\circ} 66$, p. $75-115$.

41. Corte Social atinge pelo menos $624 \mathrm{mil}$ - Crianças, Idosos e Deficientes. Folha de São Paulo, março 4; p. 6.

42. Cribier $F$. Les mos pour ledire. La vieillesse, le troisieme âge et l'âge de nos nations. Gerontologie 76: 1-8, 1990.

43. Debert GG. Envelhecimento e Representação da Velhice. In: Ciência Hoje. São Paulo; 1988. P. 61-68.

44. - As Representações (estereótipos) do Papel do Idoso na Sociedade Atual. In: Anais do I Seminário Internacional "Envelhecimento Populacional: Uma agenda para o final do século" Brasilia; 1996.

45. Delemeau J. Prólogo. En Historia de la Vejez: de la Antiguedad al Renacimento. In: Minois G. Madrid: Editora Nerea; 1987.

46. De Masi D. O Ócio Criativo. Rio de Janeiro: Sextante; 2000.

47. Demo P. Avaliação Qualitativa. Coleção Polêmicas de Nosso Tempo. São Paulo: Editora Cortez; 1987.

48. Donnangelo MCF, Pereira, L. Saúde e Sociedade. $2^{\text {a }}$ ed. São Paulo: Livraria Duas Cidades; 1987.

49. Featherstone $M$. The Body in Consumer Culture. In: $M$. Featherstone et alli (orgs). The Body Social Process and Cultural Theory. London: Sage; 1992. 
50. Ferrari MAC. O Envelhecer no Brasil. Rev. O Mundo dá Saúde. 1999; São Paulo: Ed. do Centro Universitário São Camilo; p. 197-203.

51. Fillenbaum GG. The wellbeing of the elderly. Approaches to multidimensional assesment Genebra, World Health Organization, 1984. [Who offset publication, 84].

52. Fini MI. Sobre a Pesquisa Qualitativa em Educação, que tem a Fenomenologia como suporte. In: Pesquisa qualitativa em Educação Unimep, $2^{\text {a }}$ ed. Piracicaba: 1992

53. Forghieri YC. Esboço de um Enfoque Fenomenológico da Personalidade. Ciência e Cultura; Suplemento 41 (7): 444, 1990.

54. Apresentação: Fenomenologia, Existência e Psicoterapia In Fenomenologia e Psicologia. São Paulo: Cortez; 1984.

55. Foucault M. O Nascimento da Medicina Social - Em Microfisica do

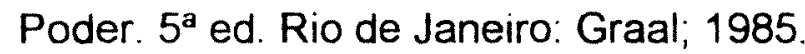

56. Galeno J. A Translation of Galen's Hygiene Trad. de M. Green. In: Minois G. Historia de la Vejez. Madrid: Ed. Nerea S.A, 1987. p. 217218

57. Geertz C. A Interpretação das Culturas. Rio de Janeiro: Ed. Guanabara Koogan S.A: 1989.

58. Gentile M. Promoção da Saúde. Rev. Promoção da Saúde. Ministério da Saúde, $n^{\circ}$ 1, agasto/outubro-1999.

59. Goldman SN. Universidade para a Terceira Idade: uma lição de cidadania. São Paulo; 1999. [Tese de Doutorado em Serviço Social PUC].

60. Gordilho A (org). Desafios a serem enfrentados no terceiro milênio pelo setor saúde na atenção integral ao idoso UNATI / UERG. Rio de Janeiro Relume-Dumará; 2000.

61. Gouveia MAF. Procedimentos Metódicos de uma Intervenção num Fenômeno Social - In: Rev. Serviço Social e Sociedade. São Paulo: Cortez; 1982. No 9 . 
62. Guareschi $P$, Jovchelovitch $S$ (orgs.). Textos em Representações Sociais. Petrópolis: Vozes; 1999.

63. Guerreiro Ramos. A Redução Sociológica. Coleção Tempo Novo 2 $2^{\mathrm{a}}$ ed. Rio de Janeiro: Tempo Brasileiro Ltda; 1965

64. Haddad EGM. A ldeologia da Velhice. São Paulo; 1985. [Dissertação de Mestrado F.F.L.C.H. Universidade de São Paulo].

65. Heiddegger $M$. Sobre a Essência da Verdade In: Os Pensadores, Trad. Ernildo Stein. São Paulo: Abril Cultural; 1979.

66. ---- Todos Nós...Ninguém. Trad. Dulce Critelli. São Paulo: Moraes; 1982.

67. - Ser e Tempo. $2^{\text {a }}$ ed. Petrópolis: Vozes, 1988.

68. Holland $W W$. Measuremente of levels of health. Copenhague Regional office for Europe, 1979. [European Series, 7].

69. Husserl E. Ideas Relativas a una Fenomenologia Pura y una Filosofia Fenomenológica. México: Fondo de Cultura Economica; 1949.

70. - Investigações Lógicas. In: Os Pensadores. São Paulo: Nova Cultural; 1988

71. International year of older Persons Launched-Active Ageing Policies are key, says Dr. Brundtland - Press Release WHO/65 - 1 October 1998 , p. $1-3$.

72. Jahoda $M$ Research Methods. In: Minayo MCS. O desafio do conhecimento.Pesquisa qualitativa em saúde. São Paulo / Rio de Janeiro: Hucitec / Abrasco; 1992.

73. Jung CG. Memórias, sonhos, reflexões. Reunidas e editadas por Aniela Jaffé. Rio de Janeiro: Nova Fronteira; 1975.

74. Kalache A, Ramos LR, Veras R. O Envelhecimento da População Mundial: Um desafio. Rev. de Saúde Pública. São Paulo: 21(3): 200210. 1987 
75. Kickbusch I. What Makes the Difference? In: $4^{\text {th }}$ International Conference on Health promotion. Jacarta: julho/1997.

76. Lane S, Codo W Org. Psicologia Social: O Homem em Movimento. São Paulo: Brasiliense; 1984.

77. Lasch C. A Cultura do Narcisismo. Rio de Janeiro: Imaco; 1983

78. Lefèvre $F$ org. O Discurso do Sujeito Coletivo - Uma nova abordagem metodológica em pesquisa qualitativa. Caxias do Sul: EDUCS; 2000.

79. -_- Mitologia Sanitária: Saúde, doença, midia e linguagem; São Paulo: Edusp; 1999.

80. Leme GLE. O Envelhecimento. São Paulo: Contexto; 1997.

81. Liberato EM. Educação continuada e Faculdade da Terceira Idade Rev. A Terceira Idade. São Paulo: 1996. № 12

82. Lima AMM de. Saúde no Envelhecimento: O Discurso Sanitário nos Programas de Saúde. São Paulo; 1996. [Dissertação de Mestrado, Faculdade de Medicina da USP].

83. Lopes RG de C. As interpretações Sociais da Saúde na Velhice, Refletidas no uso do Medicamento. São Paulo; 1999. [Tese de Doutorado em Saúde Pública, USP]

84. Marshall H. Motivations as Predictors of Health Behavior. Health Services Reports. 87(9); 852-862, Nov. 1972.

85. Martinelli L (org.). Pesquisa Qualitativa - um instigante desafio; São Paulo: Ed. Veras; 1999.

86. Martins J, Bicudo MAV - A Pesquisa Qualitativa em Psicologia: Fundamentos e Recursos Básicos. São Paulo: Educ PUC; 1998.

87. ---.- Não somos cronos, somos Kairós. In: Revista Kairós, Gerontologia. São Paulo: Educ-PUC; 1998. No 1. P 11-24.

88. Medeiros SL. Práticas Terapêuticas não convencionais usadas por Idosos. São Paulo; 1997. [Tese de Doutorado em Saúde Pública, USP]. 
89. Medeiros SAR. Jornal do CRESS. $9^{\mathrm{a}}$ região, gestão $96 / 99$, set/dez, $n^{\circ}$ 23, 1997

90. Mendes Gonçalves RB. Reflexão sobre a articulação entre a investigação epidemiológica e a prática médica a propósito das doenças crônicas degenerativas. In: Costa DC (org.) Epidemiologia Teoria e Método. São Paulo: 1990.

91. Mercadante EF. A Construção da Identidade e da Subjetividade do Idoso. São Paulo; 1997. [Tese de doutorado em Ciências Sociais PUC].

92. Merleau-Ponty M. Fenomenologia da Percepção. Trad. Reginaldo di Piero. São Paulo: Freitas Bastos; 1971.

93. - A linguagem Indireta e as vozes do silêncio. Trad. Abril Cultural. São Paulo: 1975.

94. Sobre a fenomenologia da linguagem. Trad. Abril Cultural São Paulo: 1975.

95. Minayo MCS. Pesquisa Social - Teoria - Método e Criatividade. Petrópolis: Vozes; 1994

96. --...- $O$ desafio do conhecimento: pesquisa qualitativa em saúde". São Paulo - Rio de Janeiro: Hucitec - Abrasco; 1996.

97. Ministério da Previdência e Assistência Social. Plano de ação governamental integrado para o desenvolvimento da política nacional do idoso. Brasilia: 1996.

98. Minois G. História de la Vejez - De la Antiqued al Renascimiento Madrid: Editorial Nerea S.A.; 1987

99. Moragas R. Gerontologia Social - Envelhecimento e Qualidade de Vida. São Paulo: Paulinas; 1997.

100. Moreira ASP, Oliveira DC (org). Estudos Interdisciplinares de Representação Social. Goiânia: AB; 1998: Apresentação. 
101. Motta E. Envelhecimento Social. Rev. A Terceira Idade. São Paulo: 1989. No 2

102. Moura JVC. Discurso de Jovens Grávidas: Uma Abordagem Fenomenológica - Hermenêutica à Luz de Heidegger. São Paulo: 1996. [Tese de Doutorado, Faculdade de Saúde Pública da USP].

103. Nemes MIB. Ação programática em saúde: recuperação histórica de uma politica de programação. In: Schaiber LB org. Programação em Saúde Hoje. $2^{\mathrm{a}}$ ed. São Paulo: Hucitec; 1993.

104. Neri A L. Envelhecer Num Pais de Jovens: Significados de Velho e Velhice Segundo Brasileiros Não Idosos - Campinas, São Paulo: 1991. 1993.

(Org.). Qualidade de Vida e Idade Madura. Campinas: Papirus;

106. Neto AJ. Gerontologia Básica. São Paulo: Editora Lemos; 1997.

107. Novo Dicionário Aurélio da Língua Portuguesa. $2^{\mathrm{a}}$ Ed. Rio de Janeiro: Nova Fronteira; 1986

108. Nutbeam D. Promoción de La Salud: Una antologia. Organización Panamericana De la Salud. Oficina Sanitária Panamericana, Oficina Regional de la Organización Regional de la Organización Mundial de la Salud. Washington (DC): OPS, 1996 [Publicacion cientifica n. 557].

109. Oliveira P de S. Universidade Aberta e Co-Educação de Gerações. Rev. A Terceira Idade. São Paulo: 1996. № 12

110. Oliveira WO O Corpo - Próprio e o Mundo Percebido. São Paulo: Vertentes; $1995 . n^{\circ} 5$. p.62.

111. Organização Mundial de La Salud. Applicaciones de la epidemiologia al estudio de los ancianos Genebra, OMS. 1984. [série de informes técnicos, 706].

112. Organización Panamericana de La Salud. La salud de los ancianos: Una preocupación de todos. Washington (D.C.) OPS, 1992. [comunicación para la salud n.3]. 
113. - Las Condiciones de la Salud en Las Americas. Washington (D.C.); 1994. p. 90. (Publicación Científica, 549).

114. Pacheco JL. Práticas Sociais na Promoção da Saúde do Idoso. Rev. Arquivos de Geriatria e Gerontologia da Sociedade Brasileira de Geriatria e Gerontologia. Rio de Janeiro: 1997. Vol. 1. nº 2.

115. Parse RR. Mirsing Research, Qualitative Methods. Maryland, USA: Brady Company; 1991.

116. Pereira DM. (org.) Idoso - Encargo ou Património? O envelhecer em São Paulo. Corpo Municipal de Voluntários, 1993.

117. Pinto LC. Percepção, Ensino e Aprendizagem. Rev. Educação em Debate. 1990. Revista da Faculdade de Educação da Universidade do Ceará. No 19-20. p. 1-23.

118. Promoção da Saúde. Carta de Ottawa. Declaração de Adelaide. Declaração de Sundsvall. Declaração de Bogotá. Ministério da Saúde/Fundação Osvaldo Cruz/IEC (Informação, Educação e Comunicação). Brasilia (DF): 1996.

119. Promocion de la Salud y equidad - Declaração de la Conferencia Internacional de Promocion de La Salud - Organizacion Panamericana de La Salud - Ministério de Salud de Colombia - 1992.

120. Queiroz MIP de. - Variações Sobre a Técnica de Gravador no Registro da Informação Viva. São Paulo: Ed. T. A. Queiroz; 1991.

121. Quintero MO. El Autocuidado. In: La Atencion de los Ancianos: un desafio para los años 90. OPS - Publicación Cientifica, 1994. № 546.

122. Ritton CA. A Educação na Terceira Idade e a Individuação. Bragança Paulista; 2000. [Tese de Mestrado em Educação - USF].

123 Rhodes C. An Introduction to Gerontology - Aging in American Society. Illinois - USA: Charles C. Thomas Publisher; 1993

124. SÁ CP de. Núcleo Central das Representações Sociais. Petrópolis: Ed. Vozes; 1996. 
125. Salgado MA. O Significado da Velhice no Brasil: Uma Imagem da Realidade Latino Americana. Cadernos da Terceira Idade - Sesc. São Paulo: 1982. Nº 10.

126. São Paulo. Decreto Lei $N^{\circ} 9802$, de 13 de outubro de 1997. Estabelece o Conselho Estadual do Idoso. Diário Oficial do Estado de São Paulo.

127. São Paulo. Decreto Lei n 9892, de 10 de dezembro de 1997. Institui a Politica Estadual do Idoso - PEI. Diário Oficial do Estado de São Paulo.

128. Sayeg MA. Breves Considerações sobre Planejamento e Saúde do Idoso. Rev. Caminhos do Envelhecer, Sociedade Brasileira de Geriatria e Gerontologia. Rio de Janeiro: Ed. Revinter.

129. Secretaria Municipal da Saúde - Prefeitura do Municipio de São Paulo. Programa de atenção à saúde do idoso. São Paulo: 1998.

130. Scharfstein EA. A construção da identidade social de uma pessoa idosa através do discurso. Insere textos sobre envelhecimento: Programas para a Terceira Idade: algumas reflexões. Rio de Janeiro: 1999. UNATI/ UERJ; $n^{\circ} 2$. p. $2-63$

131. Schraiber LB(org). Programação em Saúde Hoje. Rev. Saúde em Debate- Série Didática, $2^{\mathbf{a}}$ ed. São Paulo: Hucitec; 1993.

132. SEADE - Fundação Sistema Estadual de Análise de Dados.

133. Silva AT. Sentido dos Existenciais Básicos para Heidegger. São Paulo: 1991 [Dissertação de Mestrado - PUC].

134. Silva JA da. Acreditando na Velhice. In: Serviço Social e Sociedade Novos Caminhos: 1991. n 37 p. 90.

135. Silva SRC. Autopercepção das Condições Bucais em Pessoas com 60 anos e mais de idade. São Paulo: 1998. [Tese de Doutorado, Faculdade de Saúde Pública, USP].

136. Simioni AMC, Lefèvre F, Pereira IMTB. Metodologia Qualitativa Nas Pesquisas em Saúde Coletiva: Considerações Teóricas e Instrumentais - Texto, Série Monográfica, Faculdade de Saúde Pública - Departamento de Prática de Saúde Pública - São Paulo: 1997. No 2

137. Sociedade Brasileira de Geriatria e Gerontologia. Caminhos do Envelhecer. Rio de Janeiro: Revinter; 1995. 
138. Spink MJB. A Construção Social do Saber Sobre Saúde e Doença; Uma Perspectiva Psicossocial. Rev. Saúde e Sociedade. 1992. V. 1 (2).

139. Stein E. Compreensão e Finitude. Porto Alegre: Editora Ática; 1967.

140. - Seis Estudos sobre "Ser e Tempo" (Martin Heidegger), Petrópolis: Editora Vozes; 1988.

141. Steiner G. As Idéias de Heidegger. Trad de Álvaro Cabral. São Paulo: Editora Cultrix; 1978.

142. Tamaro S Vá onde seu coração mandar. Rio de Janeiro: Rocco 1996

143. The Elderly in 2005: Health and Care Steering Commitee on Future Health Scenarios - STG. London: Kluwer Academic Publishers; 1994.

144. Veras R (org). Terceira Idade: desafios para o Terceiro Milênio. Rio de Janeiro: Relume / Dumará; 1997.

145. Vernon MD. Percepção e Experiência. Rio de Janeiro: Editora Perspectiva; 1997.

146. Vigésima Quinta Conferência Sanitária Pan-Americana - $50^{\mathrm{a}}$ Sessão do Comitê Regional. Saúde dos Idosos - Envelhecimento e Saúde. Um novo paradigma. Washington D.C. 21-25: setembro/1998.

147. Yazbek MC. Classes subalternas e assistência social. São Paulo Cortez; 1993.

148. World Health Organization. Preventing disability in the elderly Copenhagem, Regional Office for Europe, 1981 (Euro reports and studies, 65).

149. W.W.W. IBGE.NET. com.br. Censo de 2000 